\title{
A-I- I
}

\section{缶詰由来の Cl.sporogenes-like strains につんて}

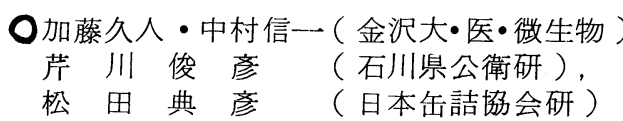

\section{目的}

缶詰食品から74株の clostridia を分離した。そ のらち62株は.Cl. sporogenes の様々思われたが， 生物性状，培養性状か $5 \mathrm{Cl}$. sporogenes と同定さ れたものは10株であり，残り52株は，成書記載と 異っているものであった（ Cl.sporogenes 類似 菌)。そこで我々は, 本研究で果して，乙の $\mathrm{Cl}$. sporogenes 類似菌群が, Cl. sporogenes 変異型と みなされるべきものか，あるいは別の species と すべきか，もし前者であれば，その変異を規制す る機構が何かを追求したいと考え検討を行った。 方法

培養性状，生化学性状, ガスクロマトグラフィー DNA homologyは, 教室慣用の方法に従って行っ た。 ( Nakamura et al., 1973: Int. J. Syst.

Bacteriol. , 23, 419-429)。

増殖曲線；ペプトン水 $(2 \%$ プロテオーゼペプ トンNo.2, Difco） $20 m \ell$ あて, L 字管に分注, 隇 菌後（滤過隇菌した糖を $1 \%$ に加える) 被検液 0.2 $m \ell$ を接種し, $37^{\circ} \mathrm{C}$ で培養, 経時的に菌の増殖を $\mathrm{OD}_{560^{-}} \mathrm{nm}$ で測定した。

胞子形成能; 培地として, BHI 寒天平板及び, $2 \%$ プロテオーゼペプトン No.2( Difco) 寒天平 板を用いた。両培地にて, 被祫菌を嫌気的に $37^{\circ} \mathrm{C}$ 48時間培盖した後，Wirtzの方法により，胞子染 色を行い顕微鏡的に胞子の有無を観察した。両培 地で共に $0.1 \%$ 以上胞子を認めた場合を(+), 胞子 をみつけることのできない場合を(-)。どちらか一 方の培地で胞子を $0.1 \%$ 以上認めた場合を(士)と段 階ゔけした。

耐熱性試験；被検菌を，BHI $37^{\circ} \mathrm{C} ， 48$ 時間培 美後，培盖菌液を $2 m \ell$ あて小試験管に分注して， それぞれ $100{ }^{\circ} \mathrm{C} て ゙ ， 1$ 時間，2 時間加熱後，加熱 培養液 $1.0 \mathrm{ml}$ ，glucose， starch-をそれぞれ $1.0 \%$, 寒天 $0.1 \%$ の割飞含む BHI $10 \mathrm{~m} \ell$ 飞移植し て，発育の有無をみた。

結果と考察
生化学性状は, 色々の型のものに分かれたが, その代表株について，ガスクロマトグラフィーを 行った結果， いずれの型も，Cl. sporogenes-近縁 群のパターンに一致した。マウスに対する毒性は, すべて陰性であった。乙の事から，てれらの菌が， Cl. sporogenes の変異型でないかと予想した。と れらの菌の大半は， sucroseを遅延分解し glucose, fructose, maltose 分解飞対して恒常性を示さな かった。乙の糖分解が variable京結果を示す機構 として, 一般には, 菌自体は分解陽性でありなが ら，菌死堿によって培地 $\mathrm{pH}$ のアルカリ化が考え られているが, この菌群の場合は，異常に早ら時 期に，自己融解が起こり，糖分解そのものが抑え られるととによるのではないかと考えるにいたっ た。この異常に早い自己融解が何によるかについ ては検討中である。

clostridia-では、そのphenotypic variationが, しばしば胞子形成能に上って左右されるので，上 述の所見を，胞子形成能との関係につんて検討し た。その結果表の如く，

(1) 形態的に胞子形成能の弱いものに圧倒的に sucrose·陽性の株が多い。

(2) 形態的飞胞子形成能の弱いものに蛋白分解能 の弱いものが多い。

(3) 形態的飞胞子形成能の弱い株は，耐熱性にお レてかえって強い。

といら成績を得た。(3の現象は奇異な現象である が，Cl. perfringens の研究で得られた成績と同一 で, 恐らくは, 加熱のもたらす胞子への共通な作 用と考えている。

表 缶詰食品から分離された clostridia の胞子 形成能, 耐熱性と生化学性状

\begin{tabular}{llllc}
\hline $\begin{array}{l}\text { Grade of } \\
\text { Sporulation }\end{array}$ & $\begin{array}{l}\text { No. of } \\
\text { strains } \\
\text { included }\end{array}$ & $\begin{array}{l}\text { Heat- } \\
\text { resistant } \\
\text { strains }\end{array}$ & $\begin{array}{l}\text { Sucrose- } \\
\text { positive } \\
\text { strains }\end{array}$ & $\begin{array}{l}\text { Strongly } \\
\text { caseino- } \\
\text { lytic } \\
\text { strains }\end{array}$ \\
\hline+ & 14 & 2 & 3 & 5 \\
\pm & 8 & 2 & 2 & 1 \\
- & 8 & 5 & 8 & 0 \\
\hline
\end{tabular}


○三和敏夫, 望月泉, 江崎孝行, 今村博務, 甲畑俊郎, 渡辺邦友, 二宮敬宇, 上野一恵, 鈴木祥一郎 (岐阜大, 医, 微生物)

目的

演者らは, 南極大陸・昭和基地周辺の土壤 から高頻度にClostridia（７菌種）を分離 した（第○０回日本細菌学会中部支部会，第 47 回日本細菌学会総会).

今回は, それらの南極由来の土壤中に於け る好気性菌と嫌気性菌の菌数分布を調べるた め定量培養を行い検討した。また対照群に岐 皁市周辺の土壤を用い比較した。

実験方法

冷凍保存中 $\left(-80{ }^{\circ} \mathrm{C}\right)$ の南極由来の土 壤 (異なる地域から8検体採取) を解凍後, 1 㭘体当り 3 部位から採り, 当教室常用の希 釈液を使用して定量培養を行つた。分離培養 には, GAM 寒天培地 (日水)を用い, 3 》

${ }^{\circ} \mathrm{C} 48$ 時間, 好気培養と嫌気培養 (steel ・wool法）を同時に行つた。嫌気培養で分離 された偏性嫌気性菌は, 当教室常法の検查を 行い,VPImanuaIに従つて同定した。好気性 菌は平板上のコロニー形態とグラム染色にと どめた。かくして土壤 $\mathrm{g}$ 当りの各菌種の菌 数を算出した.

対照群の岐阜由来の土壤 ( 4 検体) につい ても同様な検查を行い, 南極由来の土壤と比 較検討した。

結果

南極由来の土壤中には, C. perfringens が $75 \%$ \%分離されその菌数は土壤工g当り $10^{4 \sim 5}$ で最も多く分布し, 続いてC. bifermentans が $63 \%$ で $10^{2 \sim 4} / g$, C. sorde-

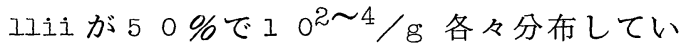
た。その他の分離菌は, C. fallax, C. ca一 daveris, C. butyricum, C. baratiが10 3 /gで, C. sporogenes, C. felsineum, C. paraputrificumが10²/gであり, 各々約 $13 \%$ 分離された。
他方, 好気性菌は同一検体から3〜 7菌種 ( $\left.10^{2 \sim 5} / 8\right)$ 分離されたのが $63 \%$ \%り, 1菌種のみ $\left(10^{4} / \mathrm{g}\right)$ ，または全く好気性 菌が分離されなかつた土壤が各々1 検体認め られた。

一方, 対照群に用いた岐皁由来の土壤から は, C. perfringens, C. bifermentans が 104〜5/8で高率に分布していたが，C.sー ordelliiは全く分離されなかつた。 また他 の Clostridia の菌種 \& $10^{3}$ 5 $/ 8$ 各検体か ら分離された。更に好気性菌は $107 / \mathrm{g}$ 以上 に分離され, 南極由来の土壤よりも菌種, 菌 数共に多く分布していた。

考察

南極由来の土壤中には, C. perfringens, C. bifermentans, C. sordelliiが他菌種に 比し, 高頻度に検出された。肢阜などの一般 土壤からは, 分離出来ないとされていた $。$ sordelliiが南極由来の土壤から検出された ことに関して演者らが以前に報告した。

南極由来の土壤中には，好気性菌よりも嫌 気性菌の方が菌種, 或いはそれらの菌数も多 く分布していた，それに反して岐阜由来の土 壤検体では, 好気性菌が嫌気性菌よりも多か つた。 
中原英臣. 石川友章 - 近藤 勇 (慈恵医大 - 細菌) - 三和敏夫 渡辺邦友・二宮敬宇 ·上野一恵・鈴木祥一郎 (岐皁大・医・微生物)

\section{(I) 目的}

三和らは、南極大陸昭和基地周㲽つ土壤か ら高頻度にCl. perfringens 分離した。(第 10 回細菌学会中部支部・第 47 回細菌学会 総会)さらに、これら南極由来のC1. perfrin 一gensにつ々て楽剤耐性の検討を加えた。（第 22 化学療法学会 ) 一方、近藤らは黄色ブド ウ球菌、大腸菌、肺资桿菌、緑膿菌沉つんて $\mathrm{Hg}, \mathrm{Cd}, \mathrm{As}, \mathrm{pb}$ とhった重金属耐性の疫学 的遺伝的倹討を行ってをた。（第30.32回細 菌学会関東支部・International symposium on bacterial resistance)今回、我々沬乙れ ら南極由来の $\mathrm{Cl}$. perfringens 飞ついて Hg, $\mathrm{da}$, $\mathrm{As}, \mathrm{Pb}$ の重金属耐性をしらべ, 岐皋市附近の 土壕由来のそれと比較した。

(II) 方法

使用菌株は，Cl. perfringens の南極由来 株 12 株と岐皁由来株 10 株を用い, 対照と して重金属耐性をもつ黄色ブドウ球菌 $248 \beta \mathrm{H}$ $-\mathrm{PC}^{\mathrm{R}}$ 株と $209 \mathrm{P}$ を用いた。検査する菌を $G$ $\mathrm{AM}$ - broth で $3 \sim 4$ 時間嫌気培養し, 各種重 金属を加えた GAM 寒天平板培地飞 $10^{-6} / \mathrm{m}$ 接 種し, $37^{\circ} \mathrm{C} 24$ 時間嫌気培養をしてから耐性 值を判定した。各種重金属としては, $\mathrm{HgCl}_{2}$ $\mathrm{CaCl}_{2} \mathrm{Na}_{2} \mathrm{HASO}_{4} \mathrm{~Pb}\left(\mathrm{CH}_{3} \mathrm{COO}\right)_{2}$ を用いた。

(II) 成積

1)対照の菌を用いて各種重金属につんて普通 寒天培地と GAM 寒天培地の比較をすると、

下表のようにAS とPbでは差がなかったが、 $\mathrm{Hg}$ と $\mathrm{Cb}$ では 5 〜 10 倍の差が認められた。

\begin{tabular}{|c|c|c|c|c|}
\hline & $\mathrm{Hg}$ & $\mathrm{Cd}$ & As & $\mathrm{Pb}$ \\
\hline & A-A GAM & $A-A$ GAM & A-A GAM & A-A GAM \\
\hline $248 \quad H-P C R$ & 20200 & 2001600 & 1600 & 1600 \\
\hline $209 P$ & 225 & 220 & 200 & 5 \\
\hline
\end{tabular}

2) C1. perfringens の南極由来と岐阜由来の 各種重金属の耐性值分布は下図に示す。

\begin{tabular}{|c|c|c|c|c|c|c|c|}
\hline 1600 & & 0 & $\sqrt{3}$ & 1800 & $188^{\circ}$ & |:\%6! & 8688 \\
\hline 800 & & 100 & 88 & 100 & 0 & & \\
\hline 400 & & & & 1800 & † & & \\
\hline 200 & 800 & 8000 & $\infty$ & & & & \\
\hline 100 & & & & & & & \\
\hline 50 & & & & 10 & & & \\
\hline 25 & 8800 & & & & & & \\
\hline P多/ & 南极这 & 南極 & 这支皁 & 南極 & 歧皇 & 南柯 & 歧阜 \\
\hline m/s & $H_{8}$ & C & & $A$ & $s$ & $\mathrm{Pl}$ & \\
\hline
\end{tabular}

3) $\mathrm{Hg}$ では南極由来 12 株中 5 株、岐阜由来 では 10 株中 9 株が耐性だった。Cd では同じ く 12 株中 3 株、10 株中 7 株飞耐性がみられ た。ASでは南極由来株に 1 株感受性菌があっ たが、他はすべて耐性菌であった。Pbでは両 者ともに同程度の耐性を示した。

(I) 考察

黄色ブドウ球菌、大腸菌、肺咨桿菌、緑膿 菌之同様に嫌気性の Cl. perfringens $/$ b重 金属耐性菌の存在が認められた。特に、南極 由来株にも $\mathrm{Hg}, \mathrm{As}$ の耐性菌が存在し、しか も岐阜由来株よりも低頻度だった事実は興味 深々。現在他の重金属 ( $\mathrm{Cu}, \mathrm{Co}, \mathrm{Ni}$ 等) や他の 南極由来株につんても比較検討中である。 
I 目的 …擞生物の分類の基本の一つは集団と集 団の関係の研究にあると考える. 集団には小さい集団 もあれば，大きい集団もある．小さい集団である株の 集団が speciesとなり，speciesの集団が genusであ るという様に順次上位階級ほど大きくなっているが, これを整然とした分類階級 (taxonomic rank) とする には,それぞれの集団の大きさの規定および集団と集 団との関係を比較できるようにする必要がある.

II 方法…微生物の種の相互の比較をより客観的 にするためのアプローチは, Sneath(1957)により考 案された similarity value(S-value)によってより合 理的なものとなっている.しかし多数ある菌種あるい は株をまとまりのある集団とするには，集団と集団の 境界線をどのように引くか, またさらに集団と集団の 大きさの比較を容易ならしめるためには，もう1つの 概念が必要となってくる.これがすでに林 (1964)が 報告した実在の center species (分類中心種) であ る.集団を center speciesに求心的に集約させ,そ の集団の代表として, 他の集団の代表である center species と比較することにより可能となる. 菌種 (侏) についてのみ考えられた似たものに Liston ら (1963) の想定の理論中心生物 (hypothetical median organi sm) および束村ら (1968) の理論平均生物 (hypothetical mean organism) がある.

集団の代表としての center species は, 集団の大 きさを規定するのにも用いられる．菌種は株の集団 といえるのでHalococcus 属の種 (株)についてその S-valueをしらべ, 菌株の集団 (菌種)としての大き さを確定する (即ち囷種の確立) 必要がある.その上で 菌種の集団である genusについて選ばれた center speciesからの各菌種との S-valueによりgenusの大 きさを実験データにもとづいて考察し，順次それぞれ の genus の center speciesについて,さらにtribe および family(Coccaceae 科) について考察を加えた 上で, 推論的に order, class, divisionの各階級にお けるそれぞれの center species間のS-valueについ
て考察する.

次に Lysenko \& Sneath (1959) は $1-\mathrm{S}=d$ により $\mathrm{S}-\mathrm{value}$ を距離 $d$ に変えることができると報告し， S-value を距離の概念に転換した。そこで我々はそ れぞれの集団を立体的なものと想定し，dの值を各分 類階級に適用して $d=2 r$ ( $r$ 半径) として立体的に $\frac{4}{3} \pi r^{3}$ に換算してみた. 即ち分類階級のそれぞれの代 表の center species相互のS-valueより換算して， 上位階級と下位階級の相対的な容積比より genus 中 にどれ位の speciesが, tribe 中にどれ位の genus が,さらに family 中にどれ位の tribe が含まれうる かを, 各階級について推論を試みた。

III 成績 …実験的データおよび理論的考察により 分類階級のそれぞれの center species間の S-value （\%) は次の如く定める.〔前の報告 $(1964,1968$, 1971 )に修正を加えた了

Species $93 \pm 7$, Genus $78 \pm 14$, Tribe $64 \pm 14$

Family $50 \pm 14$, Order $36 \pm 14$, Class $22 \pm 14$ Division $7 \pm 7$

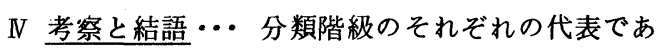
る実在の center species の概念の適用により集団と 集団の比較が容易となると共に, 集団の大きさをきめ る時,さらに一定大きさの集団と集団 (階級 ) の境界 をきめる時即ち新菌㮔をどの genusに所属させるかを きめる時にも center speciesが必要である.

株の集団としてのspeciesをcenter species(strain) により確立した上, genus の代表としての center species を選び，これを用いて順次上位の階級のcenter species 相互の此較により分析・整理すること ができる。

実験值および理論値よりみて上記の各階級の cen-ter species 間の一定範聿のS-value (\%) は各々の分 頪階級を示すものと考えられる．従って各分䅡階級の それぞれの大きさの規定は上記の数值を適用すること により可能であろう。 


\section{$A-1-5$ \\ Enterobacter と Klebsiella の分類につんて}

\section{今井紘, 坂野 勲(財発酵研)}

\section{且的}

Enterobacteriaceae 科に属する細菌の有 機酸膜透過系を比較する目的で、有機酸の利 用性をしらべたところ、ク属】ワ種の細菌の 中で、トリカルバリル酸を利用したものは、

Salmonella 属 3 種と Enterobacter aerogenes に限られていた。一方、Aerobacter aerogenes Beijerinck とかつて同定されたものの 中に、Enterobacter aerogenes と Klebsie巩a pneumoniaeの中間的性状を示す菌株が見 いだされた。 Enterobacter と Klebsiella の 類縁関係を明らかにする目的で、トリカルボ ン酸の利用性につんてしらべ、更に、Klebsiella ， Enterobacter に属す菌株の計数分 類を試みた。

方 法

分類学的性状は Manual for the Identification of Medical Bacteria ( Cowan and Steel )を主に参照してしらべた。

有機酸の利用性は、（ $\left.\mathrm{NH}_{4}\right)_{2} \mathrm{SO}_{4} \mathrm{Ig}$ ， $\mathrm{K}_{2} \mathrm{HPO}_{4} 7 \mathrm{~g}, \mathrm{KH}_{2} \mathrm{PO}_{4} 38, \mathrm{NaCl} I g$, 蒸 留水 $1,000 \mathrm{ml}$ の組成のものに別隇菌した炭素 源を $0.5 \%$ 加えた培地でしらべた。

計数分類にお忖る相似度は、Sokal and Michenerの計算式に従つて求めた。 結果及び考察

ここで使用した Klebsiella 2株は、トリカ ルバリル酸，イソクェン酸を利用できなかつ たが、Enterobacter aerogenes 2株は、てれ らを利用した。 Klebsiella と Enterobacter aerogenes の中間的性状を有する 6 菌株の中 で、2株はトリカルバリル酸, イソクエン酸 を利用でをなかつた。トリカルバリル酸を利 用した残り 4 株のうちろ株は、イソクエン酸 を利用でをなかつた。トリカルボン酸の利用 性に関しても、これら6菌株は中間的性状を
示したので、約 60 の分類学的性状にもとず さ、計数分類を試みたところ、Enterobacter aerogenes と $85 \%$ 以上の相似度を示した。 しかし、これら 6 菌株の中.で2株は Klebsiella とも85〜90\%の相似度を示し、 Enterobacter aerogenes $と$ Klebsiella pneumoniae は非常に近縁な種であるととを 示唆する結果を得た。 
斎藤 肇, 清谷克寛, 山岡弘二 (広大・医・細菌)

目的

ネズミらい菌の生物学的並びに生化学的諸性状 を既知の遅育抗酸菌のそれらと比較検討し，もっ てての菌の分類学的位置を明らかにする。 方法

ネズミらい菌警視庁株並びに対照として結核菌 群 (Mycobacterium tuberculosis H37Rv, M.bovis Ravenel および M. microti D-15), 非定型抗酸菌 I 群 (M. kansasii ATCC 12478 およブ M. marinum ATCC 927), 同 II 群 (M. marianum ATCC 19981およびM. gordonae ATCC 14470) 並びに同 III 群 ( $M$. avium ATCC 15769, M. intracellulare ATCC 15985, M.xenopi ATCC 19250,M. ulcerans P.D., M. gastri ATCC 15754 および M. nonchromogenicum ATCC 19530) の各 5mcg へミン加 1\%小川卵黄培地上 air-loose での 2 4週間培養菌を供 試し，それらについての 1 . 集落性状,2,3. 集落の着色 (暗所, 1 時間懪光後), $4 \sim 8$. 発育温晴 ( $30,37,42$, $\left.45^{\circ} \mathrm{C}\right), 9.1 \%$ 小川培地上での発育, $10 \sim 27.0 .5$ $\%$ ニコチンァマイド， $0.5 \%$ デオキシコーレート， $0.03 \%$ ピロニン, $0.1 \%$ 亜硝酸塩, $3 \%$ 食塩, 10 および $20 \mathrm{mcg} / \mathrm{ml}$ 窒化ソーダ, 250 および $500 \mathrm{mcg} / \mathrm{ml}$ パラニトロ安息香酸, 1,5 および $10 \mathrm{mcg} / \mathrm{ml} \mathrm{FAH,} 125$, 250 および $500 \mathrm{mcg} / \mathrm{ml}$ ヒドロキシルアミン並びに 250,500 および $1,000 \mathrm{mcg} / \mathrm{ml}$ サリチレート各含 有 $5 \mathrm{mcg}$ ヘミン加卵黄培地上での発育, 28. 鉄 取込み，29. 中性紅反応，30.ナイアシン・テスト， 31. 硝酸塩還元, 32 . Tween 80 水解, 33 . 酸性 フォスファテース， $34.70^{\circ} \mathrm{C}$ 酸性フォスファテース， 35. アリールサルファテース，36，37. カタレース（泡 沫の高さ<10mmおよび $>20 \mathrm{~mm}), 38.68^{\circ} \mathrm{C}$ カタレ ース, 39〜41. プロピレンディアミン, プトレスシ ンおよびカダベリン分解, 42〜51. Bönicke の 10 種 のアミデース, の計 51 性状から菌種間 Similarity value を Sneath のAdanson分類法に従って求め, ネズ そらい菌と既知菌種との間の異同性について検討する。 成績および考察

1)ネズミらい菌の性状：R型, 非光発色性, 遅
育性， $30^{\circ}$ および $37^{\circ} \mathrm{C}$ の発育 $(+), 42^{\circ}$ および $45^{\circ}$ $\mathrm{C}$ の発育 $(-)$, 中性紅反応 $(+)$, 鉄取込み $(-), 1 \%$ 小 川培地上での発育 $(-)$, 各種薬剂含有培地上での発 育一ニコチンァマイド( (), デオキシコーレート( () , 亜硫酸塩 $(\rightarrow$, 食塩 $(-)$, ピロニン $(+), 10 \mathrm{mcg}$ 窒化ソ 一ダ(+), $20 \mathrm{mcg}$ 窒化ソーダ( $(-), 250 \mathrm{mcg}$ パラニ トロ安息香酸 $(+), 500 \mathrm{mcg}$ パラニトロ安息香酸( $($ ), ヒドロキシルアミン( (), サリチート( $(十)$ 。ナイアシン・テスト( $($ ), 硝酸塩還元 $(-)$, アリ ールサルファテース $(-)$, Tween 水解 $(-)$, 酸性フ オスファテース( $(-), 70^{\circ} \mathrm{C}$ 酸性フォスファテース( (), プトレスシンオキシデース(-), カダベリンオキシ デース( (), プロピレンディアミンオキシデース( () , カタレース (発泡の高さ $<10 \mathrm{~mm}), 68^{\circ} \mathrm{C}$ カタレー ス(-), Bönicke のアミデース・シリーズ中ニコ チンアミデースおよびピラジンアミデース(†)。

2)齐ズミらい菌と既知非光発色性抗酸菌との鑑 別点：結核菌群とはネズミらい菌が $250 \mathrm{mcg}$ パ ラニトロ安息香酸に耐性, $1 \%$ 小川培地上の発育 並びにユリエースが陰性の点において鑑別可能で あった。病原性 III 群非定型抗酸菌とはネズミらい 菌が $\mathrm{R}$ 型で $1 \%$ 小川培地での発育並びに $68^{\circ} \mathrm{C}$ 力 タレースが陰性の点においててとなった。雑菌性 III群非定型抗酸菌とはネズ々らい菌が $\mathrm{R}$ 型で, 1 \%小川培地並びに $250 \mathrm{mcg}$ サリチレート含有卵黄 培地上での発育, Tween 水解, 酸性フォスファ テース, $70^{\circ} \mathrm{C}$ 酸性フォスファテース, アリールサ ルファテースのいずれも陰性の点において鑑別可 能であった。

3)ネズ之らい菌と既知遅育抗酸菌との近似性： ネズミらい菌は供試いずれの菌種との間の近似性も 低く,最もその高かった M.tuberculosis とでさえ $65 \%$ の Similarity value を示したにすぎなかった。

如上の成績より北里研究所小川博士によって培 養されたネズこらい菌は末だ記載をみない独立した分 類学的位置を占める 1 抗酸菌と思われる。 


\section{$A-1-7$}

新菌属Kitasatoaにつんての研究

松前昭広 豊田小夜子 高橋真知子 星野寿雄 吉福幸治 木村 明

(北 研)

目的：新菌属 Kitasatoa は 1968 年松前と 秦により命名され本学会総会上で発表した。 4 菌種 K.purpurea，K.diplospora，K.kauaiensis と K.nagasakiensis を含み Bergy's Mannual, 8ed K Actinomycetes , Actinoplanaceae 属しGenus 10 亿記載された。 その諸培地上の生育諸性状は Streptomycetaceae，Streptomyces 飞極めて類似するが、 本菌属はクラブ状の Sporangiaを有し水中で 遊泳する diplococcus like Cylindrical $\sim \operatorname{rod}$ 状の極在性一本鞭毛のzoospore を有 する。本菌属に属する 4 菌種は全てクロラム フェニコールを生産する。

Actinomycetes の分類はその細胞壁組成中 ๑ meso-, L-DAP, Glycine, Arabinose, Galactose, $X_{y}$ lose, Madurose の存在に基づいて分 類される。しかるにKitasatoaについては未 だ報告を行っていない。今回は本菌属に属す る菌株の全菌体と細胞壁区分の構成了ミノ酸 と糖についてペーパークロマトグラフィおよ び薄層クロマトグラフィで得られた結果と、 ガスクロマトグラフィで得られた結果とを比 較し併せて脂肪酸についても述べる予定であ る。又新たに見出した本菌属に属する新菌種 についてその諸性状を報告する。

実験方法: 振盪培盖 72 時間の培養液 $0.1 \mathrm{ml}$

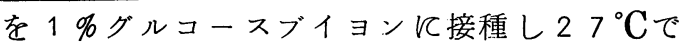
振盪培養した。菌接種後 24 時間後から 168 時間充での菌体を一定時間毎に集菌し水で洗 浄後更にEtoHで洗浄し、EtoHV24 48 時間浸漬した。乙れを乾燥して全菌体とした。 全菌体を水に再浮遊し細胞破砕器( ブラウン ( M SK type) 社製)で菌体を破壊し3000 rpm 5 分遠心して得られた沈査に pepsine， trypsine,pronase, DNase および RNase を $37^{\circ} \mathrm{C}$ で作用させ洗浄後凍結乾燥して細胞壁区分
とした。電顕下では細胞壁が主成分であった。

菌体中のアミノ酸とアミノ糖の検出は細胞 壁区分之全菌体を $6 \mathrm{~N} \mathrm{HCl}$ で $100^{\circ} \mathrm{C} 18$ 時間 加水分解後塩酸を除いて試料とした。展開は $\mathrm{MeOH}: \mathrm{H}_{2} \mathrm{O}: 10 \mathrm{~N} \mathrm{HCl}:$ Pyridine(80:17.5: $2.5: 10)$ を用い、0.4\% Ninhydrine液で現像 した。構成糖は $2 \mathrm{~N} \mathrm{H}_{2} \mathrm{SO}_{4}$ で $100^{\circ} \mathrm{C} 2$ 時 間加水分解後 $\mathrm{Ba}(\mathrm{OH})_{2}$ でPH $5.0-5.5$ とした 後乾燥し水に再溶解して試料とした。溶媒は 前同様とし anilineacid phtholate 液で現像 した。ガスクロマトグラフィには 3 \% HCl $\mathrm{MeOH}$ で $100^{\circ} \mathrm{C} 3$ 時間 Methanolysis 後石 油エーテルで抽出した。MeOH層をガスクロ マトグラフィにかけた。石油エーテル層をガス クロマトグラフィにかけ脂肪酸をしらべた。又 アミノ酸の場合はペーパークロマトグラフィに用い た試料を用い Norleucineを標準として検出した。 新菌種の同定はActniomycetes の鑑別法に従った。 結果及び考察：Kitasatoaの構成了ミノ酸は Asparatic acid, Threonine, Serine, Glutamic acid, Proline, Alycine, Alanine,Valine, Methionine, Isoleucine, Leucine, Tyrocine, Phenylalanine , $\mathrm{NH}_{\mathbf{3}}$, Ornithin,Lysine, Histidine, Arginine, L-DAPおよび mesoーDAPなどであった。糖 としてはGlucose，Mannose，Ribose を有し Galactose を欠除し Arabinose は不明であっ た。XyloseとRhamnoseは含有していない。 集めた zoosporeを同様に処置して調べたとてろ 両DAPとる欠除すると考えられる結果を得た。 4 菌株および新菌種を含む5 菌株の中で K.kauaiensis のみ他他 4 菌株と構成糖が異 なり Galactose の存在が認められたので再 検討中である。 


\section{江田 亨, $\bigcirc$ 神田弥生, 中田和江，木村貞夫（帝京大・医・細菌）}

\section{目 的}

L- form の微細構造についてはすでに報告し たが今回はその増殖過程を明らかにする目的でメ ンブレンフィルターによる沪過実験とあわせてさ らにその微細構造を検討した。

\section{材料と方法}

用いた菌株は演者らが分離したA 群溶レン菌 $\mathrm{L}$ 一 form $124 \mathrm{~L}$ 株, 大腸菌 L-form EcL 株で ある。培養は $\mathrm{L}-$ form 液体培地（ B H I， 4 \% $\mathrm{NaCl}, 10 \%$ 馬血清， $0.5 \%$ 酵母エキス)を用い

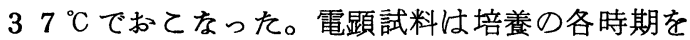
経時的に samplingし,グルタールアルデハイド, オスミック酸の二重固定後, エタノール・アセ卜 ン脱水，エポキシ樹脂に包埋した。沪過実験は一 定時間培養後, ミリポアフィルターの pore size の大きいもの $(5 \mu)$ から順次小さいもの $(0.1 \mu)$ へ通過させ，菌数計算をおこなった。 結 果

1） L - form は培養のいずれの時期においても 大小さをざまの多形性を示し,大型 $(3 \mu \sim 15 \mu)$, 中型 ( $500 \mathrm{~nm} \sim 2 \mu$ ) 細胞では細胞の中心部に D NA fiber 様構造がみられるが小型細胞 ( $25 \mathrm{~nm}$ 〜 $500 \mathrm{~mm}$ ) ではみられない。培養の初期は大型 細胞 ( $5 \mu \sim 10 \mu)$ ) 圵較的多くみられる。培 荃後期の大型細胞は空胞化しているものが多いが 初期のものは ribosome が多くdensi ty が高い。 培養初期の大型細胞ではさわめて複雑な細胞集団 を示す像がみられた。すなわち数 多方向から割面が入り，数個の細胞に分割されて らる。分割された各細胞の大きさは依とんどが 1 $\mu$ 以上の大をさである。また中型細胞では割面が 一ヶ所で， 2 分裂像を示しているものがみられた。 分裂細胞は共に周辺部に ribosome が多く局在し 中心部にはDNA fiber樣構造がみられる。大型細 胞はしばしば空胞様構造を有し，その中には 100 $n m \sim 1 \mu$ の大さの細胞がみられることがある。
また空胞て面して budding 像がみられるととも ある。大型，中型細胞ではいずれの時期でも budding がみられ，その大ささは $100 \mathrm{~nm} ３ 00$ nmのものが多く，ribosome K富んでいる。大型 細胞からは数ヶ所の budding がみられた。

2）沪過実験をおてなった結果，2株に共通にみ とめられたととは，培養の初期には比較的大をな 細胞 ( $5 \mu$ 以上) が多かったが，培養の経過とと 子に中型細胞 $(0.45 \mu \sim 0.65 \mu)$ の比率が多くな った。を培荃の各時期におらて $0.1 \mu$ 以下の細 胞には増殖能がないととが明らかとなった。

\section{考 察}

$\mathrm{L}$ - f orm の増殖機構については多くの見解が あり，なお不明の点が多い。以上の結果から演者 らは L - formの増殖機構として下図のよらな仮 説を考えたい。すなわち，通常は大型・あるいは 中型細胞が分裂あるいは buddingにより増殖する が，一部は細胞内に小型の娘細胞がでを，それが 親細胞の崩壊とともに遊離し，そのうちのでく少 数のみが増殖していく経路も存在する可能性もあ る。

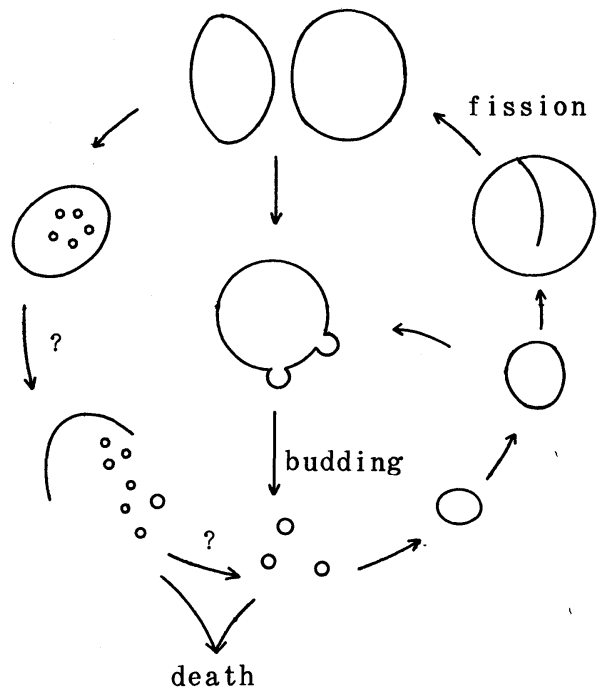


I 超微細構造

\section{○太田房雄・福井公明・吉田長之（徳大 - 医・細菌） \\ 樫山達夫（德大・総研電顕班）}

序論 近年、細胞壁のない菌、Iーformが持続感 染症を説明するものとして注目を浴びるようにな つた（Sharp，1970）。乙の異型菌が、いわゆる “細胞壁抗生物質”に上る治療に反応しない例、 再感染の考えられないしかも成巧治療後の再燃例 ペニシリン抵抗株による感染例に関連があるかも 知れない。淋菌の L-form形成に関しては二・三 の論文が見られる（Roberts，1968，Lawson， 1973)。しかし、これらの論文はその形成方法と 光顕下における形態につんて記載しているにすぎ ない。ての論文では polyvinylpyrrolidone

（PVP）とペニシリン（PC）の存在下に誘導した 淋菌の L-formにつんて、電顕下に観察した超微 細構造につけて報告する。

実験材料と方法 G C 基礎培地に化学補充素を加 えた培地 (CDAC) 飞 16 時間培養した淋菌をDifco の脳、心抽出液飞 $1.5 \%$ 寒天、 $10 \%$ 不活化馬血清 1,000 単位 $/ \mathrm{m} 1$ ペニシリン、 7 \% PVP を加え

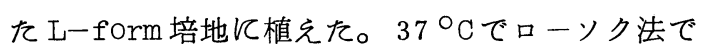
培養後、現われた工集落を $5 \%$ グルタールアルデ ヒドと $1 \%$ オスミウム酸で固定して、アセトンで 脱水後エポン樹脂に包埋して薄切とし、酢睃ウラ ニール、クエン酸鉛で二重染色して電顕で観察し た。比較の為 16 時間 CDAC で培養した正常細胞を 同様に処理して対照とした。

結果と考察正常な淋菌細胞は比較的、形、大さ さが均一で、細胞壁、細胞質膜よりなり、細胞内 には、ミクロソーム、核様体、メソン゙ームが見ら れた。乙れと対し、上細胞は、形、大をさ、構造 が不均一で、通常正常細胞より大をかった。ある 細胞は細胞壁がなく、他のものはその断片が残存 していた。ある細胞は殆んど細胞質がなく、核緎 維で満されていた。またある細胞は正常の細胞と 同様ミクロソーム、核様体も見られた。特に興味 あることは、種々の形、大をさの膜小胞体（MV） が、これらのし細胞の外側、内側に見られた。ま
た小型のし細胞が大きいし細胞中に見られた。あ る小胞体は内部に電子密度の高い中心をもってい た。このMVは蹃膜炎菌の工細胞で見られたEBであ るよらである（Roberts，1968）。このE B はお そらく細胞質膜が切れてでをたものであろら。ま た単位膜よりなる層板が工細胞の外側、内側にも 見られた。乙れら $\mathrm{EB}, \mathrm{L}$ 細胞、その他の構造物と の関連性、また、これらの工細胞がどのよらに再 生するかを知るにはさらに研究を要する。使用菌 株の供与を受けたカナダ国立保健機構疾病コント ロールセンター細菌血清部の B.Diena, F.Ashton 両博士に感謝します。 


\section{。梁川 良・本多英一 (北大・獣医・家畜衛生)}

\section{要 約}

ヒトおよび動物由来の 11 種のCorynebacte rium,すなわちbovis, di phtheriae, equi , hoagi i, kut scher i, mur i sept i cum, pseudod i pht her it icum, pseudot uberculos is, pyogenes, striatum,およびxerosis,は、いずれも線毛を 有しているてとが認められた。その形態はC: renale でさきに報告された線毛とよく似ていた。 したがって、このような線毛が少くともヒトや動 物由来のコリネバクテリウムには普遍的に存在す るととがわかつた。

\section{目的}

さきにCorynebacterium renale の3つの型 がんずれも線毛を有するととを報告した（Yanagawa \& Otsuki,J.Bact.,1970)。ついで線毛の 化学的および免疫学的性状 (Kumazawa \& Yanagawa, Infect . Immun . , 1972 ;J ap.J.Microbi o1.,1973）およびトリプシン処理ヒッジ赤血球 を凝集する能力 (Honda \& Yanagawa, Infect . Immun .,1974)についても報告した。そてでコリ ネバクテリウム属の他の菌種にも類似の線毛があ るのではないかと考えてすず電子顕微鏡的に検討 した。

\section{材料および方法}

用らた菌株はヒトおよび動物由来のコリネバク テリウムで次の如くである。C.bovis ATCC7715, C.diphtheriae ATCC 19409 および杉山株、C . equi ATCC 6939,C.hoagi i ATCC $7005, \mathrm{C} . \mathrm{ku}-$ tscheri ATCC 15677, C.murisept icum ATCC 21374, C.pseudodiphtherit icum ATCC 10700 , C.pseudotuberculos is ATCC 809 ,C.pyogenes ATCC 19411,C.striatum ATCC 6949,C.xero$\mathrm{sis}$ ATCC 373 。

これらの株を普通寒天培地をたはウシ血清寒天 培地に培養したものを蒸留水に浮遊し、メッシュ にのせ、濾紙で余分の液を吸引した後パラジゥム shadowingあるいは 1 \%燐タングステン酸でnegative stain t行い電子顕微鏡で観察した。

結 果

調べられた 11 菌種は多少にかかわらず線毛を 有していた。線毛を比較的多数有していたのは diphtheriae およびkutscheriで数十本ないし 100 本程度を有し、striatumがこれに次ざ、他 の菌種の線毛はより少数であつた。束をなして長 く伸びる線毛は pyogenes, bovis, mur isept icum などに確認された。線毛の長さはかなり幅がある

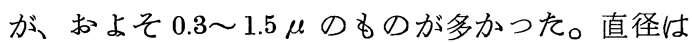
shadowingではおよそ8m odiphtheriticum では幾分短か目であつた。 negative stainでは直径はより短く計測された。 線毛は全体的には柔い感じで、グラム陰性菌線毛 のようにや〉かたい感じではなく、C.renaleの 線毛に似ており、乙れはコリネバクテリウム属に 共通と思われた。但し C.renale II 型菌のように 数百本に及ぶ多数の線毛を有する菌種は認められ なかつた。

考察

ヒトや動物由来のコリネバクテリウムの 11 菌 禈が線毛を有しており、しか子線毛の形状がC. renale で我々がさきに報告したものとかなり似 ていたととは興味梁い。C.renale II 型菌のよう に多数かつ束をなして長く伸びる線毛を持つ菌種 は認められなかつたので、との点からもC.renaleII型菌は独特であると言えよう。このようにコ リネバクテリウム属の菌種に線毛は広く認められ たが、形態以外の諸性状や機能は今後の問題であ ろ5。 


\section{A-I-I I}

Corynebacterium renale の線毛による動物細胞への付着

\section{。本多英一、梁川良（北大・獣医・家畜衛生）}

\section{要 約}

1. 線毛を多く持つC. renale strain 315 (I 型菌）、46 (II 型菌)および 42 (III型菌) は BHK 21 細胞、イヌ珡初代培盖細胞およびウサギ腎初代 培養細胞によく付着するととが顕微鏡下で認めら れた。しかし線毛ををわめてわずかしか持たない ATCC 19412はとれらの細胞にはほとんど付着し なかっ。

2. ホモの抗線毛血清で処理された C.renale strain 115 およびホモの抗全菌血清で処理され たC.renale strain 46 および 42 はHK-21 細 胞にはとんど付着しなかった。このととは、C. renale の細胞への付着は線毛によるととを示し ている。

3. 電子顕微鏡により、線毛を多く持つC.renale は分離された細胞の膜によく付着しその付 着は線毛によることが確認された。

目的

我々はグラム陽性菌で最初に見出されたCory－ nebacterium renale の線毛の機能の解明をめ ざしている。さきとC.renale はトリプシン処理 ヒッジ赤血球を凝集するてと、そしてそれは線毛 によるととを報告した (HONDA \& YANAGAWA

Infect.Immuni ty, 1974)。そこで次にC.renale 線毛は動物細胞にも付着する性質があるので はないかと考え検討した。

材料と方法

用いたC.renale は線毛を多く持つstrain 115 ( I 型菌 )、46 ( II 型菌)、4.2( III 型菌) お上 び線毛ををわめてわずかしか持たないATCC19412 （Ｉ型菌）である。対照としてグラム陽性菌で線 毛を持たないS.aureus を、グラム陰性菌で線毛 を持つK.aerogenes を用いた。

培盖細胞の浮遊液と菌液を混合し $377^{\circ} \mathrm{C} 1$ 時間 後ギムザ染色し顕微鏡（400 倍）下で調べた。ま たShmookler ら (1974)の脱核の方法を応用して
調製した細胞の膜と菌液を混合し $377^{\circ} \mathrm{C} 1$ 時間お レた後電子顕微鏡で調べた。

成 績

C.renale のらち線毛を多く持つstrain 115 46 および 42 は BHK-21 細胞、イ又腎初代培養細 胞およびウサギ腎初代培養細胞にそれぞれよく付 着するととがギムザ染色標本で認められた。しか し線毛をわずかしか持たないATCC 19412はそれ らの細胞に㹸とんど付着しなかった。

C.renale が付着した BHK-21 細胞の数を 100 個以上かぞえたとてろ、線毛を多く持つstrain 115、46 和よび 42 が付着している細胞の数（\%) は平均 $70.5 \pm 1.9 \% 、 69.2 \pm 4.0 \%$ および $70.8 \pm 3.1 \%$ であつた。しかし線毛をわずかしか持たないATC C 19412が付着している細胞の数は 30.8土3.8\% にすを゙なかった。

strain 115 をホモの抗線毛血清で $37^{\circ} \mathrm{C} て ゙$ 処理 すると传とんど細胞に付着しなくなった。また strain 46 小よびstrain 42 をホモ抗全菌血清 で同様に処理した場合にもほとんど細胞に付着し なくなった。

ホモの抗線毛血清で処理されたstrain 115 が 付着している細胞の数は $22.0 \pm 5.6 \%$ 、抗全菌血清 で処理された strain 46 および 42 が付着してい る細胞は $22.3 \pm 2.6 \%$ よび $21.7 \pm 2.1 \%$ であつた。 電子顕微鏡によって、C.renale が線毛を介し て細胞の膜に付着している像が観察された。 考察

以上の実験上り、C.renale の細胞への付着は 線毛によるものと考えられる。乙のととはC.renale の感染における線毛のはたす役割を考える 上で重要であろう。 


\title{
$A-1-12$
}

\author{
緑のう菌線維状フアージpfのエ \\ 一テル感受性につんて。 \\ ○天児和暢 安仲 加公子、(福大、医、紲菌)
}

且的

線維状形態をすつフアージとしては大腸菌を宿主と するfd、M/3、緑の菌を宿主とするpfなどが知られて らる。pfは武谷、天児により見出された緑り菌 K株を 宿主とするフアージで、大腸菌のfdと異り、雄株特異 性がなく、長さもfdの約 2倍の大ささをもつている。 我々はこのフアージの溶菌液を得る際に通常のフア 一ジに用いられているクロロホルムによつて宿主菌を 殺し溶菌させる方法を用いたとてろ、フアージが急速

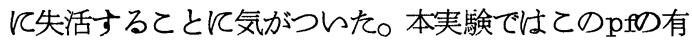
機溶媒に対する感受性を同じ線維状形態をもつfdフア 一ジと比較検討し $\mathrm{pf}$ 構造中でのリピドの在存の有 無を明らか机するととを目的とする。

方法

フアージおよび宿主菌

pfl土大細菌学教室で分離され、凍結乾燥保存され ていたpf一/である。宿主菌は緑の菌K株である。

大腸菌を宿主とする線維状フアージとしてはpfを 用いた。宿主菌はK/2 Hfr Hである。

これらの菌は通常のブロスを用いて培養を行つた。 培養温度は3 $7^{\circ}$ Cである。

フアージの有機容媒に対する感受性は次の上うにし て調べた。

低速遠心（3000回転30分）に上り除菌した フア 一液（/ $0^{\prime \prime} \mathrm{pfu} / \mathrm{m} 1$ 以上）と等量の有機溶媒を試 験管内で混合する（室温）。水と混和しない場合は水 層の部分を、混和する場合は混合液を採りその中のフ アージ量をプラック法で定量した。

\section{フアージの精製 \\ pfおよびfaは次のようにして精製した。}

pf 溶菌液上り20\%の硫安沈澱法で、 $f$ dは2\%の ポリエチレングリコールで沈潎濃縮する。

濃樎したフアージは、分画遠心法（30000 回転 2時間内、10000回転 30分) と csc工の密度 勾配遠心法で精製した。

\section{電顕観察法}

フアージ液と等量のエ一テルを／Ｏ分間室温で混和 し静置後、エ一テル層と水層に分ける。水層を一部採 り、カーボンを張つたマイクログリッド上に置さ、2 \%リンタングステン酸カリを用いネガテイブ染色を行 つた。

結果と考祭

pfおよびfdの有機溶媒に対する感受性は表のごとく である。

fdはクロロホルムでのみ失活するが $\mathrm{pf} は$ は一テル， クロロホルム、アセトン、メタノールでほづ完全に失 活してしまう。

エーテル処理フアージを電顕で観祭すると、フア一 溡有の線維状形態が失なわれ 巾 $300 \mathrm{~A}$ 程度の太く 短構造物之巾 $50 \mathrm{~A}$ 程の細い多数の線維が観察され た。これらの構造物とフアージの本来の線維状構造と の関連についてはまだ明らかでない。

ウイルスのエ一テル感受性は勘物ウイルスではリピ ドの在存を㘥味する性質として広く知られている。フ ア一ジにおいてその構造にリピドの在存が知られてい るものはシュドモナス属の菌を宿主とするPM-2と 中6であり、動物ウイルスにくらベリピドをもつたつ ア一ジは極めて少ない。 pf がエ一テル感受性である ことはその構造にリピドあることを強く示唆するもの である。リピドの分離とその定性を行つていく予定で ある。

\begin{tabular}{lrl}
\hline & pf & \multicolumn{1}{c}{$f d$} \\
\hline 無双理 & $1.3 \times 10^{11}$ & $4.2 \times 10^{11}$ \\
7007ホル4 & $<10^{3}$ & $1.5 \times 10^{9}$ \\
エーテル & $<10^{3}$ & $3.6 \times 10^{11}$ \\
×タール & $<10^{3}$ & $3.2 \times 10^{11}$ \\
Pヒトー & $<10^{3}$ & $3.0 \times 10^{11}$ \\
\hline
\end{tabular}


ロ崆スピロヘータの免投学的研究

とくに歯肉組織に扣ける局在性と

抗体O P C A 活性について

○佐川寛典・梅本淩夫（大阪歯大・細囷）

目的

歯周病の発症ととの症状や释過が、歯肉溝 内に定住する細菌鋠と密接な関連性を有して いると云う竍告は、多くの研究者によって指 摘されている。しかしながら霜周病を病因論 的に検索したとしても、歯肉構内の構成細菌 のいずれによって、その起炎菌として、また 病像の主没を演じているかについては、定説 は見あたらない。厸達は従来、口腔スピロへ 一タが Treponemal antibody 打よびWasserman antibodyを㛢起する抗原性を有してい ることや、これらの抗体が歯周病患者血清中 に認められることを竍告し、雪周病と口腔ス ピロへータとの関連性について示唆して来て。 そこで今回は口腔スピロへータ可溶性抗原と 抗スピロへータ冢兔血清とUP C A 反応打よ びロ些スピロへータの雨周病患者歯肉組織に 扔ける局在性について。蛍光抗体法とを用い て、霜周病に打ける病因を免没学的に解明す ることを目的とした。

方 法

実哙に使用したロ腔スピロへータは、人の 口腔より分晟し、Spirolate broth (BBL) に $15 \%$ の馬血清を加え、ガスパツク法で嫌気 的条件で、3 $7{ }^{\circ} \mathrm{C} 、 5$ 日間培養したものを用 いた。培養後。6 000 r. p. m 20 分间遠 心集囷し、pH7.0 の P B S で5 回洗條、その 沈渣を涷結乾燥して使用した。抗スピロへ一

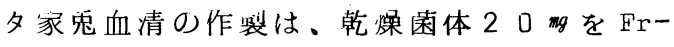
eund's complete adjuvant と共に、家鬼の 皮下に5 日間隔で 5 回接㮔したのち採血し。 血清を分晟した。抗血清中の免収グロブリン の分画は、2.6×100 cm のラムを使用し Sephadex G200 で行つた。分画された口空 スピロヘータ抗体と、对照として、抗スピロ へ一夕家兔血清と免没処埋をしはかつた家鬼
血清の各々 $0.1 \mathrm{~m} \ell$ をルモツト背部皮内に接 梗し、latent timeを打いて、足謶静脈より 口腔スピロへータ可溶性抗原をEvans'blue と共に注射し、P C A 反応を行つた。蛍光抗 体法については。歯周病患者の切除歯肉組織 を抗スピロへータ血清にFluoresecent isocianate conjugateしたもりで染色した。

恄 果

抗スピロヘータ血清より。IgG, I g M の 2 分画を得、P C A 反㐫を行つた結果、抗スピ ロへ一タ冢兔血清と。そのIgG画分には強い P C A 反応を認め。IgM画分と、対照血清に 扣いては、P C A 反応はまつたく諮められな かつそ。荬周病患者の霜肉租織に打ける口悾 スピロヘータ抗原り局在性については、20 例中、17例に誌められた。

考 察

近年、歯周病り病像が。雪肉局所に打ける 免没反応を背景としている傾向が強いが、今 回私達が行った実跧成績によっても、腔 ピロへータ抗原と、IgG抗体とり間には。強 いP C A 反応が認められ、また、口崆スピロ へ一夕抗原が歯周病患者歯肉に対して高染に その局在性があることが雄認出来たことから 考えて、歯周病の発症について、ロ控スピ口 ヘータが、兔没学的レベルで何らかの関与を している可能性を見出し、病因の解明に示唆 をあたえたものと思われる。 
歯苔の免疫学的活性

（5）歯苔微生物叢の免疫学的活性物質

○片山有夫, 北野繁雄, 玉監敬一, 足利 照,

堀 良隆, 宮川政子(城西歯大・微生物)

目的われわれは,さきに, 歯苔による抗体 と感作リンパ球に依存する免疫応答につらて 報告を行い, また，昨年の本学会では，歯苔 による抗体産生反応が歯苔構成素材のうち， その嫌気性微生物群て顕著であるととを報告 した。なお，乙の嫌気性微生物群は $10^{7}$ cells の接種でモルモットに実験ワンサン.感 染を発症させる。

今回は, 歯苔嫌気性微生物群の免疫活性物 質の初歩的な分画を試みたのち，乙れらの分 画について, 主として遅延型皮内反応を指標 とする免疫学的活性を検討した。

方法 歯苔嫌気性微生物群—30名の被検 者加成熟歯苔を採取し, 直ちにガス噴射法 のるとでEugon broth中に接種, $37^{\circ} \mathrm{C}$, 5 日間嫌気培盖を行つたのち, 遠心沈殿で集 菌し, 滅菌生理食塩水で三回洗條したのち, 以下の実験に供試した。

抗原の抽出および分画—菌体をSonication とFrench press で破壊抽出し, 遠心 沈殿を行い, 上清を歯苔嫌気性微生物群可溶 性抗原とした。この可溶性抗原液は塩酸で $\mathrm{pH} 4.0$ とし, 沈殿する画分 (粗蛋白画分, $\mathrm{F}$-P) と上清に分けた。上清はさらに NaOH で中和（ pH サ.O）し，濃縮したのちEthanol 5 倍量で沈殿する画分 ( 粗多糖体画分, $\mathrm{F}-\mathrm{S})$ を得た。

免疫学的性状 i）皮内反応：採取した 成熟歯苔 $1 \mathrm{mg}$ を腹腔内に接種したモルモッ 卜を用い, 反応用抗原として, 粗蛋白画分 $0.1 \mathrm{mg} \mathrm{N}$ と粗多糖体画分 $20 \mu \mathrm{g}$ を また対 照には歯苔無細胞抽出液 $0.1 \mathrm{mg} \mathrm{N}$ を用いて 感作モルモツト皮内に注射し，24時間後に square method で測定し, 各抗原の活性は対 照の歯苔抗原との ratioで表わした。ii）沈
降反応：通法の double diffusion 法飞従つ て行つた。

粗蛋白画分の蛋白分解酵素による消化一 papain, pronase, pepsin, trypsin, chymotryps in を用い，基質の $1 / 100$ 量の 酵素で $37^{\circ} \mathrm{C}, 15$ 時間, 各酵素の至適 $\mathrm{pH}$ 下で作用させた。

粗抗原の精製——i) 粗蛋白画分は Sephadex G-200による gel filtration $V$ より分画を行い，G-1とG-2の画分を得た 。ii）粗多糖体画分は sevag 法で除蛋白の 後, DEAE-cellulos $\theta$ column 亿加け, $\mathrm{H}_{2} \mathrm{O}$ で溶出したのち NaClの gradient elution を行いDーIの画分を得た。

結果および考察 歯苔嫌気性微生物群菌体抽 出液から $\mathrm{pH}$ 4.0 で分画した蛋白性抗原の皮 内反応活性は papain などの proteaseにより 減弱したが，なお本活性は相当残留し，また この抗原分画および多糖体性画分を精製して ゆくと皮内反応活性は多糖体画分では増強す るが，蛋白性画分ではその傾向が微弱であつ た。従つて今回の実験内容では一定の結論を 与えるととはできないが, 現在の段階では皮 内反応活性を中心とする歯苔免疫活性因子と しての多糖体にわれわれは注目している。 
B-I-3 ヒト梅毒に応用したマクロフォージ遊走阻止試験（M． I. T. ）

$\mathrm{o}$ 田中忍・富樫博之・鈴木貴和・沼田岳二 ( 北里大・衛生・免疫 )

小野田洋一（都立台東病）

上野陽・河島敏夫（都立大久保病）

目的

梅毒の治療指針の検査化を目的とし、家鬼並び にモルモットの実験梅毒を用いて、本疾患と細胞 性免疫との関連性を追求してをた。それ等の成績 については第 30 回及び 31 回の本学会関東支部 総会の席上で報告したが、Treponema Pallidum （以下 T。P.と略す）を培養抗原に用いたM.I.T. が実験梅毒に応用可能であるといら示峻を得た為、 今回は本反応をとト梅毒に応用した結果を報告す る。

方法

患者検体は主として都立大久保・台東両病院よ り提供を受けた。M.I。T.は直接法を使用し、ED TA 添加により採血した末梢血から Conray-Fic 011法を用いてリンパ球を分離した。マクロフォ 一ジは正常モルモットの腹腔内細胞を用い、両者 の混合比は細胞数にして（ $1: 2)$ と定めた。培 養時の抗原としては、約 6.00 条数 /視野の T.P。 抗原液を超音波処理したものと、補体結合反応用 のカルシシオライピン抗原液との 2 種を用いた。同 時に血清反応につ々てもVDRL 法、THHA 法、T PIA法を実施した。乙れ等三血清反応が共に陰性 である 38 例について実施したM。I。T.の結果か ら $95 \%$ の危険率における下限許容限界值 $(\mathrm{P}=0$. 95 )を算出し、T.P.抗原を用いた M I . T。の陽 性判定限界值は $75 \%$ と定めた。

結果および考察

これまでのとてろ 47 例の患者について実施し た。血清反応ではVDRL 法に於て 10 例が原液に て陰性であり、TPIA 法では 1 例が陰性であった が、TPHA 法では全例が陽性であった。一方 T。P 。 抗原を用いたM。I.T.の結果は、3例を除いた全 検体が陰性値を示した。血清反応に於て梅毒陽性 と判定される质とんど全ての検体に和らてM。 I . T。 が陰性であったととから、ヒト梅毒に本反応を応 用する意義は認められないとも言えるようである
が、第一に既に発表した如く、実験梅毒における 成績から、感染早期に本反応が陽性結果を示した こと、第二に今回実施した検体の㴗とんどが、長 期治療中のものであるとと等を考えあわせ、今後 は早期梅毒の、しかも出来るならば未治療の患者 について応用を試みたいと現在検体依頼中である。 また陽性結果を示した 3 例については経過を追う 予定であり、同時に全ての検体につんて臨床面で の経過を確認中である。

なお、との研究はワクスマン財団研究助成金を を受けたものであります。 
S. derby およびS. oranienburg のフラジェリンイみられる heterogeneity

○土肥 義)背, 天野 恒久（阪大，医，細菌）

新家. 荘平, 小松 俊憲（阪大微研, 免疫化学)

要約

1・サルモネラ属の鞭毛蛋白質フラジエリンは、 $8 \mathrm{M}$ 尿素の存在下では均一な蛋白質であるが、 尿素の非存在下では、周囲のイオン環境により 互に移行しうる少なくとも6種の比較的安定な モノマー状態准移し得るととを明らかにした。

2.それらは、免度化学的纪異なる二つの群に分 けられるととから、とのフラジェリンの状態の 推移は、加なり大をな立体構告変化を含んでい るととを明らかでた。

且的

フラジェリンのイオン交換クロマトグラフイーの 場合、再クロマトに際して、フラジェリンは、多 峰性の溶出曲線をもつてクロマトされる。ての理 由を追求する間て、フラジェリンが低イオン強度 溶液中で、数種の状態に変化している事走見出し たので、それぞれの状態てついて、物理化学的、 免疫化学的検諳を加える事を目的とした。

材料之方法

1。菌株：S. derby NCTC1729 株 $(4,5,12: \mathrm{fg} ;-)$

と S. oranienburg NCTC5743株 $(6,7: \mathrm{mt} ;-)$ を主 化用いた。

2。フラジェリンの調製: 鞭毛を塩酸によつて脱 重合、超遠沈 $100,000 x g 、 90$ 分飞よる酸不溶物 の除去、苛性ソーダによる中和、Sephadex G150 によるゲル濾過、限外濾渦濃縮後、DEAE cellulose クロマトにより精製純化した。

成績と考察

1。フラジェリン (Fi)は、8 M尿素の存在下で、 polyacrylamidegeldisc 電気泳動(PAG)を $\mathrm{pH} 8.6$

对 $\mathrm{pH} 2.7$ で行つても均一な易動度を示し、生 食水交溶媒として超路汾分析すると単一の波形で その $\mathrm{S}_{20}$ は 2.8 であるので、上記 $\mathrm{Fi}$ 封、純粋 で安定なモノマーである。

2。Fi 溶液を、例えば、トリスのグリシン緩衝 液に透析しためのは、尿素の非存在下で PAG（pH
8.6)を行うと、鋭い4本の染色带を示し DEAE cellulose 『よる再クロマトでは、主に4 つのビ 一クを持つパターンがみられる。しかし、超遠沈 分析を行らと単一の波形であり、 $8 \mathrm{M}$ 尿素存在下 での PAG は一本の染色带を示し、更に SDS を 用いた PAG 於ても一本の染色帯を示すととか ら、上記緩衝液中でば、Fi が少なくとも4 種の モノマー状態をとつている事が示唆され、会合や 分解をおこしているのではない?

3. 各状態の $\mathrm{fg}$ フラジェリンを抽出して検索す るため、デイスク電気泳動法の原理を使用した cellulose acetate 膜デイスク雲気泳動沠を工夫 して泳動を行うと、4本の鋭い濃い染色带の他、 2 本の淡い染色带 (易動度の大きいるのより順に I〜VI とする) 加潅察された。上記 PAG と同様 結果と考えられたので、6本の染色带位置より蛋 白を、泳動に用いたトリス塩酸緩衝液で溶出して その安定性を検討した結果、少なくと数日間以 上に亘り安定であつた。

4.それぞれのFr.虫疫化学的飞検討した。抗 fg フラジェリン血清（主视V含む Fi で免疫） を用いて、三重拡散法を行うと、I〜VIいずれる 一本の沈降線を形成し、IとIIIII とIVとVとVI のそれは、それぞれ互に fuse するが、正(又はIV，

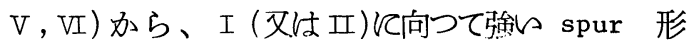
成がみられ、これらて群の間《は、かなり大をな 立体構造上の差異のある事加明ら汃ななた。 5. Fi は「鞢毛表在吽の serotype 沉対応する 抗原決定群」と鞭毛のフラジェリン分子間の接 触面と内面に対応する決定群」とを有している(第 2 回、免疫学会絰会、1972 年)。前若、即ち serotype 因子抗原の内 $\mathrm{f}$ と践は、I〜VIい ずれの状態にも存在する事㗞認された $\left(8_{4}\right.$ 亿つ いては検詩中)ので、上記2群の差異は、後者の 決定群の変化による事が示唆されるが、この面に ついて、目下、更に詳しく検討中である。 


\section{B-I-5}

ボッリヌス菌の表在性抗原に関する研究

第 3 報 巴型菌のグリコペプチド抗原の分離とその性状

宅見賢二。永尾重喜.川田十三夫（德大。医。栄責衛生）

要約

ボソリヌスヌ型菌の精製細胞壁標品よりホルムアミド抽 出により蛋白非分解性ボソリヌス菌に共通な抗原を分離 したっとの抗原は還元糖、アミノ糖、アミノ酸拉よび 燐酸を含むグリコペプチドより構成され、リビトールお お よどグリセロールは含なない。

未精製細胞壁標品のD O O 抽出物から 2 種の抗原物 質を分離した。これらの抗原を免疫化学的に比較検討 した。

且的

ボツリヌス $\mathrm{E}$ 型菌 Saroma 株の精製細胞壁からホルム アミド 抽出により表在性抗原が得られるととてついて はすでに報告した（日細誌 $29 ； 165 ， 1974$ )。今 回はこの抗原の免疫化学的性状の検索まよび $\mathrm{E}$ 型菌以 外のボツリヌス菌間における同抗原の分布を検討した。 また細胞壁の精製過程で得られる抗原物質について分 離と精製を行ら免疫電気泳動的に荷電の異る2 種の抗 原画分を得を。以上 3 種の抗原の相互関係を検討する。 材料と方法

菌株と抗血清：主に巴型Saroma 株およびIwanai 株の定常発育菌より細胞壁を調製した。抗血清は Saroma 加熱死菌ウサギ免疫血清と、ホルムアミド処理 細胞壁 (Saroma 株) を音波処理で可溶化後Freund の不完全アジニン゙ントと共にウサギ皮下接種して得を抗 血清を用いた。抗原の分離と精製：10\%ホルマリン 固定菌を Bühler ホモジナイザーで破壊し繰返し分別遠 沈して得を細胞壁を出発材料とした。 $1 \%$ デオキシコー ル酸ナトリウム（ＤＯＯ）飞上記細胞壁を $10 \mathrm{mg} / \mathrm{m} \ell$ （ary weight）に浮遊させ $37^{\circ} \mathrm{C} て ゙ 15$ 時間振とう 処理後遠沈し上清は流水、ついで精製水に透析し凍結 乾燥した（ＤＯＣ抽出物）。細胞壁沈椬は繰返し水洗し た後 1400 のホルムアミドで抽出し抽出液に 10 倍量 の冷アセトンを加え生じる沈澱物を水に唀析し不溶物を 除いた上清を凍結乾燥した（ホルムアミド抽出物）。各 抽出物はDEAEーセルローズカラム（０.01Mトリス埕酸楥 衝液 pH H.2 ) V办け、緩衝液で溶出後更にNacl の濃
度勾配 ( O 0.5 M)で溶出し、各フラクション中の溶出物 は2 $254 \mathrm{~nm}$ よど還元糖発色(硫酸 フエノール法)で モニターし抗原活性は重層法により確㑊した。得られ た抗原画分はSephadex G-75 を通して精製標品と した。抗原性状の検討は常法て従った。

\section{実験成績と考察}

D O C 抽出物はそのまつではゲル内沈降反応 (オク テロニー 法)で2本の沈降線を示したがこれら 2種の 抗原は DEAEーセルローズカラムで互いに単離された。 免疫電気泳動では移動方向が逆である。陽極側にむ办 ら抗原画分（DOC-1）は $254 \mathrm{~nm}$ 吸収と還元糖の 発色を示したが陰極側にむから抗原画分（ＤＯ－2） はいずれる陰性であつた。ホルムアミド抽出物を上記力 ラムに加けると食塩濃度が $0.1 \mathrm{M}$ 附近の溶出液に抗原 活性が認められた。乙の抗原 ( F S 抗原) (Sephadex G-75カラム $(1.8 \times 85 \mathrm{~cm})$ 亿办け $0.1 \%$ 酢酸で溶出す ると inbibed volume 亿単一ピークとして現われた。 F S 抗原の化学組成は $\operatorname{lucos} \theta$, galactos $\theta$, glucosamine, galactosamine, alanine, histidineおよび燐を主成分とする。 $2 \mathrm{~N}$ 塩酸、 $1000 、 3$ 時間の加水分解物ではリビトール、グリセロ ルともに検出されなかつた。免疫電気泳動では中央原 点を動かない1本の沈降線を示した。定量沈降反応 （抗血清 $0.1 \mathrm{~m} \ell$ ）で添加抗原量 $5 \mu \mathrm{g}$ 《最大沈降蛋白 量を示し、その反応は $50 \mu$ モルのmethyl $\beta-D-$ gluc oside の存在下では后ら゙90\%阻害された。ま たhistidine $25 \mu$ モル添加で約 $50 \%$ 阻害された。 蛋白非分解性ボソリヌス菌 (B. F型) 加ら同様にして 得られた各菌株のF S 抗原は用いた $\mathrm{E}$ 型全菌抗血清に 対して完全に融合する1本の肬降線を示した。 ボツリヌス菌田型の表在性抗原の一つは燐を含むグリ コペプチドで糖アルコールを含をないてとから通常のタイ コイン酸とも異るようである。 
梁沢義村, ○加賀谷けん子, 西川朱実, 篠田孝子 (明治薬大・微生物)

目的：われわれは，ゼラチン化脂質粒子が新 鮮血清の存在下で補体の関与なしに種々の動 物組織に粘着するととを見出し，乙の現象を 正常粘着反応 (Normal adherence reaction) とよび，乙の反応に関与する血清成分を粘着 促進因子 (Adherence promoting factor-APF と略す）と名づけ，正常食作用における付着 現象 (attachment)の一部はこのカテゴリース 入るるのと考えた。われわれはすでにAPF は 易熱性の19S 血清成分であり, ガン, 肝硬変 および自己免疫疾患などの患者においては著 名な低下がみられるととを報告したが，乙の 度はさらにAPFを分離精製し, その免疫化学 的性状を明らかにするとともに, その生理学 的意義を追求するととを試みた。

方法: 粘着反応はゼラチン化脂質乳剂一ラッ 卜肝組織片の系を用いて行なった。すなわち, ポリエチレン製小試験管飞検体 $1 \mathrm{ml}$, ラット 肝組織片 $100 \mathrm{mg},{ }^{125} \mathrm{I} て ゙$ 標識したゼラチン化脂 質乳剤 $0.1 \mathrm{ml}$, ヘパリン25単位を入れ, $37^{\circ} \mathrm{C} て ゙$ 30分間振と5する方法を用的た。反応後遠心 により上清を除を, 組織片をKrebs-Ringer buffer(KRB) で洗浄後, $\boldsymbol{r}$ ーシンチレーシ ョンカウンターで組織片に粘着した乳剤の量 を測定した。対照としてKRB $1 \mathrm{~m} \ell を$ 用いて同 様の操作を行なった。

APFの精製のため飞は, 正常ヒト血清を 0.008M EDTA, pH 5.4 で透析し euglobulin 分画老得灰。DEAE-Cellulose column chromatography は, 0.02M Phosphate buffer, $\mathrm{pH} 8.0$ を出発緩衝液とし, $\mathrm{NaCl}$ の濃度勾配 により溶出させた。Sephadex G-200による ゲル濾過は0.01M PBS，pH7.2を用いて行な った。ブロック電気泳動はペビコンC-370を 支持体として, Veronal buffer, pH8.6, $\mu=$ 0.05 を用いて行なった。ゼラチンのSepharose
への結合は, CNBrで活性化された Sepharose 4 B を $\mathrm{pH} 8.6$ でゼランと反応させて行なった。 結果: 1. ヒト正常血清を用いた吸収試験の結 果, APFは S. typhimuriumおよび $\mathrm{S}$. aureus の加 熱菌, マウスの肝組織片, ゼラチンを結合さ せたSepharoseゲルにより吸収されたが，若。 albicansの加熱菌, ウシ血清アルブミンおよ びウシの $イ$ ーグロブリンの aggregate では吸収 されなかった。2.ヒ卜正常血清の e uglobulin 分画をDEAE-Celluloserょり分画すると, $\mathrm{APF}$ 活性は $\mathrm{NaCl}$ 濃度 $0.1-0.2 \mathrm{M}$ で溶出される ピークに存在し，乙の分画をSephadex G-200 でゲル濾過を行ならと, APF活性は19S分画 に存在した。またブロック電気泳動飞ょり $\mathrm{APF}$ 活性は最も陽極側のピークに存在するこ とがわかった。この精製 $\mathrm{APF}$ は免疫電気泳動 にょり抗ヒト血清と 1 本の沈降線を形成した が, 抗ヒトIgM血清, 抗ヒト $\alpha_{2}-\mathrm{Macrog} 1 \mathrm{ob}-$ ulin血清とは沈降線を形成しなかった。3.患 者血清のAPF 值を粘着反応飞より調べた結果, ガン患者の約 $80 \%$ が低下を示し, 肝硬変, SLE では検査したすべての血清がAPF 值が低下し ていた。考察：以上の結果ょり, $\mathrm{APF}$ は IgM和よび $\alpha_{2}-$ Macroglobul in 以外の $19 \mathrm{~S}$ 成 分であり, 動物組織や微生物細胞の表層飞存 在するゼラチン様の構造をもつタンパク質に 親和性をもつてとがわかった。オプンニンと して正常食作用を増強するととが知られてい る自然抗体和よびプロパジンが補体を必要と するのに対してAPF は補体を必要とせず，限 られた構造のタンパク質を認識する防御機構 の一つと考えられる。正常粘着反応の機序と APF の本態を解明するととは異種識別と排除 の機構を明らかにするらえに重要であり，ま そAPF 值の変動梳生理的飞子病理的飞もをわ めて重要な意義をもつととが示唆された。 
日本細菌学雑誌 $30(1), 1975$

\section{B-I-7}

実験コレラにおける抗菌免疫

○氏家淳雄、

且的抗菌抗体はコレラ菌に吸着すること によつて感染防御効果を示すが、その機序 を明らかにするため次のことを検討した。

1)溶菌素が菌に吸着したとき、どのよう にして防御と関連するのか。

2)抗菌抗体を吸着させたコレラ菌で経口 感染したときの正確なる腸管内消長は ぞうなのか。

\section{方法}

1)コレラ菌の加熱死菌で免疫して得たマ ウス抗血清を適当にうすめてコレラ菌液と 混合し、余分の抗体を遠心操作で除いた菌 液を型の如くICR 系の乳のみマウスに経 感染し、一定時間毎に腸管をとり、コレラ 菌を算定した。溶菌素吸着コレラ菌は補体 処理により溶菌するので、直接に算定する 方法がない。従つて補体処理をしても溶菌 しない菌を算定して、間接的に溶菌素吸着 コレラ菌の消長を推定した。結果的には感 染後短時間内に補体処理で溶菌しないで集 落を形成する菌数が増加してくる現象が認 められた。同様の実驗をinvitroで検討 したが、即ち溶菌素吸着菌液をheart infusion brothに接種し、一定時間毎に サンプルをとつて検討したが、同柆なる現 象が認められた。

かかる現䔨は溶菌菜が菌から解離するた めなのか、菌に吸着している状態で補体依 存性溶菌活性がなくなるためかを解明する ため、接種後溶菌率の著明に減少した時点 で再び同じ抗血清を作用させ、その中に含 まれる溶菌素がかかるコレラ菌に吸着する か否かを飧討した。なお実験を通じて、 ストレプトマイシン耐性菌を用い、ストレ プトマイシン（SM）含有培地で算定した。

2)腸管内のコレラ菌を算定するのに通常 TCBS培地平板を用いているが、感染実験で 高度希䣋菌液を算定する必要のあるときは TCBSは極めて不正確である。従つてSM高度 耐性菌及びクロラムフエニコール（CM）耐 性菌を用いて感染し、SM $200 \mathrm{mcg} / \mathrm{ml}$ 又は $\mathrm{CM} 6 \mathrm{mcg} / \mathrm{ml}$ を それれに含む普通寒天培 地平板を用いて感染コレラ苜の算定をした 。かかる培地を用いることによつて、腸管 内フローラの増殖を㧤さ正確なる算定为 できたと思う。
(山梨衛研)

結果および考察

1) 溶菌素を吸着したコレラ菌は感染 又は培養後短時間内で補体処理による溶 菌を示さなくなる。invitroでは約 4 〜 $\mathrm{hr}$ で完全になくなるが、この時点で は腸管噌殖は認められず又感染防御効 果の認められる以前である。かかる菌液 に再度、同じ抗血清を作用させても新し く吸着しないことを考えると、溶菌素吸 着コレラ薄が補体処的しても溶菌しない ことは菌に吸着した溶菌素が菌から解離 するためではなく、菌に吸着した状態で 不活化したと考えられる。しかもその時 点を考えると感染防御に関与するのは溶 菌素の有する溶菌活性とは関係なく、そ れが単に吸着するた如生ずる何かに依 るものと考元易い。

2) 耐性苚を用いて感染儿耐性培地 で算定した腸内におけるコレラ莀の消長 は抗血清を混合しない菌液で感染した場 合、感染後 10〜 $15 \mathrm{hr}$ も経つてから感染 菌の増殖が認められる。このことは感染 菌の全部が腸管内増殖するのではなく、 限られた少数の菌のみが適当な場所で増 殖し、10〜15 hr 後に感染菌数より多く なり増殖として認められるようになるも のと思われる。適当なる増殖部位はぜこ かというとまだはつきり言えないが、上 皮に接した粘液層を考えている。抗血清 を混合して感染したときは即ち抗体吸着 コレラ菌で感染すると、感染後 10〜 15 $\mathrm{hr}$ ごにみられる増殖が抑制される。こ のことより抗体吸着菌は粘膜を通つて増 殖部位に達するのが障害されるのか、増 殖部位に達してからそこに遊走している 食細胞に食菌され易くなるためかわから ないが増殖部位で増殖に関与する菌数が 制限されるためと考えている。

とにかく乳のみマウスを用いた実験コ レラに関する実験を通してコレラに対す る抗菌免疫を論じたい。 


\section{B-I-8}

免疫殺菌反応と one-hit theory

。井上公蔵, 木下 タロウ, 秋山曜子, 岡田真理子,

北条史子, 茶園 正至, 東 雍, 天野恒久(阪大,医,細菌)

目的：Mayer の提唱したimmune cytolysis 称けるone hit theoryは、彼および彼の門 下によつて免疫溶血系で解析され、特にBorsos らによるC2 反応段階の解析等によつて確 立された。免疫殺菌反応飞未いてもての説 の成立が考えられながらも、その方法論的困 難さから末だ確立されていない。本研究の 目的は、単一成分飞よるhit 加ら、補体系飞 みられるが如を、多成分の連鎖反応の結果と しての hit を含めての理論的解析を確立し、 それを用いて免疫殺菌反応がsingle hit 江よ るか multiple hits 飞よる加を確立するにあ る。

材料及び方法：免疫殺菌系として、E． coli B/SM、それ対するウサギ抗血清及びモルモ ツト補体血清を用いた。抗血清及び補体血 清は bentonite 処理により1ysozymeを除去し たすのを用いた。対照系には560、60分加 熱非㗢化補体を用いた。Streptolysin 0 は 日水㹕薬の子のを、⒈ perfringens $の \theta$ toxin としては、当教室で PB 6 K 株より分離せる toxin 非産生株の培養濾液を用い、ヒツジ赤 血球の溶血でしらべた。

数学的解析：一定反応容量中で一定量の補 体を用い、感作菌数を変量して加える系を考 えると、r hitsを受けた菌の比率は、Poisson の分布式办ら $P_{r}=\frac{\mathbf{z}^{\mathbf{r}}}{\mathbf{r}} \mathrm{e}^{-\mathbf{z}}$ で与えられる。

もし n hits以上を受けた菌のみが殺されると すると、、 $\begin{aligned} \sum_{r=0}^{n-1} \operatorname{Pr} & =\sum_{l=0}^{n-1} \frac{z^{r}}{r !} e^{-z}=\sum_{r=0}^{n-1} \frac{\left(\frac{N}{x}\right)^{r}}{r !} e^{-\frac{N}{x}} \\ & =1-\frac{y}{x}\end{aligned}$

ここで $\mathrm{y}:$ 殺された菌の数

$\mathrm{x}:$ 加えた感作菌の総数

$\mathrm{N}$ : 補体成分の effective sets の総数 $z=\frac{N}{x}: 1$ 感作菌当りのhits 0 平均数

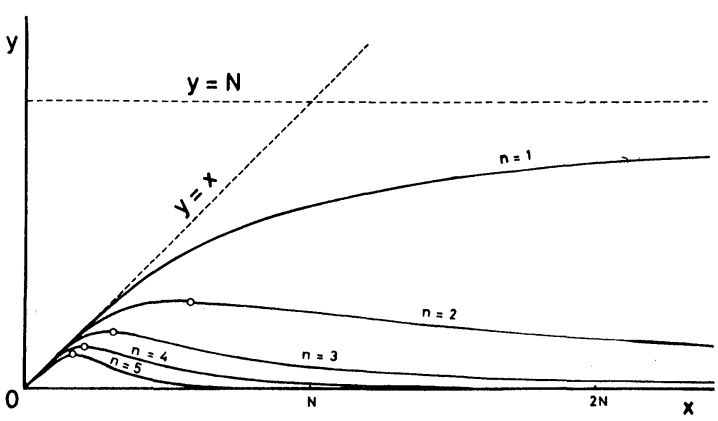

である。

式を整理して、

$$
y=x-\sum_{r=0}^{n-1} \frac{N^{r}}{r !} x^{-(r-1)} e^{-\frac{N}{x}}
$$

$\mathrm{n}=1$ の場合、

$$
y=x\left(1-e^{-\frac{N}{x}}\right)
$$

式(1)を追跡すると、原点で傾斜 $=1\left(45^{\circ}\right)$ で立上り、 $\mathrm{x} \rightarrow \infty$ で水平 (傾斜 $=0$ ) となり、 $\mathrm{n}=1$ では $\mathrm{y} \rightarrow \mathrm{N}$ であるが、その㑃の場合 $(n \geqq 2)$ ではいずれる $\mathrm{y} \rightarrow 0$ となる。 その間、

$$
\left(\frac{N}{x}+1\right) e^{-\frac{N}{x}}+\sum_{T=0}^{n-1} \frac{N^{x}}{x !}\left(\frac{N}{x}-x+1\right) x^{-x^{-}} e^{-\frac{N}{x}}=1
$$

なる関係が成立する $\mathrm{x}$ 值の所で $\mathrm{y}$ は極大值に 達する。乙の式(3)は簡単に壮解けないので、 阪大工学部の手塚慶一教授及び海尻賢二氏の で好意で computerで計算して戴いた。そ れらを用いて得られた理論曲線は困の如くな る。

結果及び考察：免疫殺菌系で得られた結果 は、 $\mathrm{n}=1$ の場命とよく一致し、免疫殺菌反応 子 one-hit theory『従うととを示した。

Streptolysin 0および $\theta$ toxin 仁よる溶血 曲線は多重 hit 曲線を示し、前者ではn=4及 至 5 、後者では 2 及至 3 の場合とよく一致した。

この点関しては他の方法でも確办められ た。更に hit 形成でてれら2毒素が相補的 に働を得るととも確かめられた。 
コレラ菌及び大腸菌の細胞壁外膜とヒト及びモルモット正常血清との反応

○久恒和仁. 近藤誠一。川田十三夫 (德大.医. 栄盖衛生)

目的

グラム陰性細菌の細胞譬は、細胞壁外膜と Rigid 層の 2 つつ層上り構成されている。我々は先きに、コ レラ菌細胞壁よりとれら 2 層とリポ多糖体 ( L P S )を それぞれ分離、精製し、その形態学的、化学的、免疫 学的性状を明らかてして来た。今回、コレラ菌と大腸 菌の細胞壁外膜と、コレラ菌細胞壁ＬＰＳとを用い、 両菌の免疫溶菌現象を形態学的、免疫学的に追究する 目的で本研究を始めた。先づ最初に両菌に対する特異 抗体が存在しない柔におけるコレラ菌と大腸菌の細胞 壁外膜、及びしＰＳとヒト及びモルモツト正常血清と の反応を検討した。

\section{材料と.方法}

コレラ菌N A G 4715 及び大腸菌Benzer 秼の 菌体破壊後、分画して得られる粗細胞壁加ら前回の報 告同様、トリプシン、リゾチーム、 E D T A を用いる 処理により細胞壁外膜を調製した。 I P S はコレラ菌 N A G 4715 株の細胞壁加らエノール・水抽出 法により分離し、超遠心、及びRNase 処理に上り高 度に精製した。抗ヒト０３ Proactivater 血清（ウ サギ)はBehringwerke 社の製品を用いた。

結果および考察

1 ) 細胞膜外膜上の “孔状損傷 "の形成：細胞壁外 膜、又は L P S $3 \mathrm{mg} / \mathrm{m} \ell$ の濃度に生理食塩水に懸 濁し、同量のヒトまたはモルモツト正常血清を加えて $37 \circ \mathrm{C} 、 90$ 分間反応させ、遠心洗浟した後、リン・ タングステン酸を用いるネガティブ染色法により電顕 観察を行つた。両正常血清との反応の結果、細胞壁外 膜に径 80-100 n m の孔状損傷が生ずるととが観察 された。両菌ともその径は同じであったが、ヒト正常 血清によりモルモット正常血清よりはや〉径の大をな 損甥を生ずるととが示された。この孔状損傷の形成は、 血清へのEDTAの添加によって完全に阻止されたが、 EGTA (Ethylene glycol tetra acetate)の添 加によつては影響を受けなかつた。

2 ) LPS のリボン状構峼の破壊：ヒト又はモルモ
ツト正常血清によって」ＰＳのリボン状構造が完全に 破壊されるととが電影的に観察された。しか子、加熱 非衝化 ( $56^{\circ} \mathrm{C} 、 30$ 分) した血清、东をは $\mathrm{EGTA}$ のみならずEDTA を添加した血清によっても同様の L P S の形熊学的構造の破壊が起とることが認められ たっとの成績は、ヒト又はモルモツト正常向清の補体 以外の血清成分、或は補体の作用なしと血清成分の夕 によってエ P S のリボン状構造が完全に破壊されるこ とを示した。

3 ) 補体 O 3 Alternate pathway の活性化: 細 胞壁外膜、及び士 P S をヒト正常血清と上記の条件飞 て反応後、反応液上清を抗ヒト C 3 Proactivater 血清に対して免疫電気泳動を試みた。その結果、反応 前の血清に只一つ検出された C 3 Proactivater ( GBG:Glycine rich $\beta$-glycoprotein) V対 する特異的讴降線が反応後、完全に消失し、代って

o 3 Activater(GGG: glycine rich $r$-glycoprotein) 亿対する新な特異的肬降線が出 現するととが観祭された。このC 3 Proactivater ( $G B G)$ の 3 Activater(GGG)への転換は、EDT A の存在によって完全に阻止されるが $E G T A$ の存在に 上っては阻止されないてとが判った。以上の成績と

2 ) 飞おける正常血清による細胞壁外膜の孔状摃傷形 成及びＰＳのリボン状構造破壊に対するEDTA及 びEGTA の影響に関する成績は、ヒト又はモルモツ ト正常血清に上る細胞壁外膜の孔状摃傷形成と L P S の形態学的樌造破壊は、補体のいわゆる C 3

Alternate pathway の活性化を伴うことを証明し てらるのと考えられる。 


\section{C-I- I}

Protein A の化学的修飾によるFe portionへの

結合性の変化。

埼玉医大 細菌 ${ }^{0}$ 新井義夫, 守屋修, 市川洋一。

目的

ブドウ球菌細胞壁由来Protein Aのヒト Ig G。 Fe portion に対する結合性については。Fe portionの生物学的機能の解析、免疫グロブリン の phylogenetic な機構の解明について注目すべ き成績が示されている。

Protein A の結合性と生物学的反応性発現の 様相について。皮内反応、Schultz-Dale 反応に ついて検討し、抗体の持つ本来の抗原抗体反応に は影響を及ぼさない事を既に報告した。

今回は主としてProtein A に種々の化学的修 飾または変化を加えて、Fe portionへの結合性 の変化ならびに修飾Protein A の免疫現象につ いて検討した。

方法と材料

Protein A の抽出及び精製操作についてはす でに報告しているが、タンク培養により得られた 黄色ブドウ球菌 Cowan-I型株をセル、ホモジナィ ザー（Braun)により破壊処理後、Jensen の法に 準じて粗Protein A を抽出した。DEAE-

Sephadex, Sephadex G-100 を担体としたカラ ム・クロマトグラフィーによる活性分画の採取後、 Affinity-chromatography, 或は Ampholine によるIsoelectrofocusing 処埋により、

Protein A を得た。

使用したProtein A ルアミド電気泳動により単一像を示しているが、 その立体構造は、円偏光二色法により確認した。

Protein A の処埋に使用した薬剤はEDTA, EDTA-Na,SDS, Triton-X100,2ME(メルカ プトエタノール)等のキレート剤、表面活性剤等 を用い、アミノ酸残基に対する反応修飾鼡、なら びに蛋白分解酵素を使用し、修飾を与えた。

結合活性の測定は、ゲル内沈降反応、塩化クロ 一ム処理感作血球凝集反応を利用した。また in

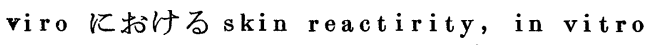

に抢ける Schultz-Dale 現象、ならびに細胞親和 性について実験した。

結果ならびに考察

精製操作としてAffinity chromatography の 使用は最終的に結合活性を問題とする場合は効果 的であった。各種キレート剤、表面活性剤の処置 はProtein A と Fe portin との結合抑制作用が いずれも認められるが、薬剂種により抑制度は相 違し、 $2 \mathrm{M} \mathrm{E}$ の抑制作用が強力であった。

chymotrypsin 処埋では比較的短時間で結合性 を失ならが、trypsin 処理では結合性はほとん ど変化しない。アミノ酸残基に対する修飾 Protein Aの生物活性の変化は in viroと in vitroとの 間に相関性については、処置法、ならびにその程 度により各々に特殊な現象として認められた。

Protein Aの Fe portion との結合性の検討 には、免疫グロブリンの機能を主体とした解明と 共に、Protein A についても種々の処理による 結合性の変化について検討することが必要な手段 であることを知った。 
$\mathrm{A}$ 群化膿レンサ球菌細胞壁より nat i veな $\mathrm{M}$ タンパク質を 分離する試み

。難波和之 (阪大・歯・口外) 加藤慶二郎，小谷台三 (阪大・歯・細菌)

且的

A 群化膿レンサ球菌細胞壁を Streptomyces globisporus が産生する endo-N-acetylmuramidase(mut anolysin; Yokogawa 5 : Ant imicrob.Ag. Chemother . 6 (2):156-165,1974)により溶解し, 型特異の抗食菌性感染防御抗原である Mタンパク 質をnativeな状態で分離する事を試みた。 方法

1)細胞壁標品： マウスを継代通過した 6 型， S43/100株のTODD-HEW I TT ブロース培養菌をBraunの 装置で破壊し，分画遠心して粗細胞壁を分離した。 2) Mutanolysin：横川博士より分与された粗酵素 を C M ルロースカラムでクロマトし, 溶解活性 当りのプロテアーゼ活性が粗酵素の約 $1 / 30$ の部 分精製標品を得た。3)抗 $M$ タンパク質ウサギ免疫 血清： $\mathrm{S} 43 / 100$ の加熱死菌 2.5 5.0 mg (湿量) ず つ的計 24 回, ウサギに静脈注射して作った。乙 の扰血清は抗 $\mathrm{C}$ 多糖体抗体を含まなかった。足立 氏（大阪市立烑山病院）秥よびMyoda 博士(Du PONT 社，USA）ょり恵与された抗 6 型おょび 12 型血清 をる用いた。4)間接殺菌テスト：Lancefield （1957）の方法に従い，へパリン加ウサギ全血液 $0.3 \mathrm{~m} \ell$ K，抗血清（対照では正常血清） $0.05 \mathrm{~m} \ell$, Trypticase SOY BROTH培盖菌を $10^{5} \sim 10^{6}$ 倍飞希釈し たすの $0.1 \mathrm{ml}$, テスト物質溶液（あるいは $0.01 \mathrm{M} \mathrm{P}-$ Buffer，pH 7.0 ) $0.05 \mathrm{~m} \ell$ を加え（全量 $0.5 \mathrm{ml}$ ) , 37 C で 3 時間， $10 \mathrm{r} . \mathrm{p} . \mathrm{m}$.で回転した。0.2 ml 篮液 寒天に混积盖して集落数数えた。

結果

1)粗細胞壁の mutanolys in 反よる浴解物 (出発細 胞壁の約 $2 / 3$ ) は抗 6 型血清とのゲル内沈降反応で 3 本の沈降線を与元，関与する抗原は結晶トリプシ ン消化で反応原性を失った。一方 Triton X-100 で処理した粗細胞壁画分の mutanolysin 溶解物 は，抗 6 型血清と 2 本の㶩降線（トリプシン処理 した溶解物では消失)を生じ，かつ両溶解物が与
える抗原則上り 2 番目の沈降線は，常法に上る酸 抽出物が与える 4 本の沈降線（いずれる関与する 抗原はトリプシン感受性)のらち，抗原側D 2 番 目のもの（Triton未処理 mutanolysin 溶解物と 酸抽出物との間では 4 番目のものも）と fuse し た。細胞壁のTriton 抽出物が示す 2 本の沈降線 は上述つ沈降線のいずれとも fuseせず，また卜 リプシン消化で反応原性を失わなかった。

粗細胞壁の mutanolysin 溶解物が抗 6 型血清の opsonin作用を中和するととが示された。一例を 挙げると，次の結果が得られた。正常血清を加え た対照沈いて，反応中に生菌数（反応系の 0.2 $m \ell$ 当り) が 41 から 1084 亿増加する条件で，抗 6 型血清を加えた系では反応後の生菌数が 59 で あった。抗 6 型血清をopsoninとして含む系に， 6 型菌粗細胞壁の mut anolys in 只る溶解物，あ るいは酸抽出物を加えた場合，反応後の生菌数は それぞれ674と605であった。すなわち粗細胞壁 をmutanolysinで処理するととにより抗"opsonin" 活性を持つ物質が可溶化でをた。

考察

細胞壁溶解酵素を使いM·タンパク質を温和な条 件で抽出する試みは，Krause(1958)，および Kantor とCole(1960) Kょり phage-associated 1ysinを用いて行なわれた。また Schmidt(1965) は，Streptomyces albus酵素のプロテアーゼ活 性をDFPによりおさえたすのを用いて、Mタンパク 質存可溶化している。しかしFoxの指摘のように これらの抽出物には核酸やC多糖体が含まれてお り，nativeな $M$ タンパク質を純化する目的は達成 されていない。今後粗細胞壁を核酸分解酵素処理 後, Tritonで抽出し, 細胞質膜由来の成分を除い たものを出発材料とし，mutanolysinによる細胞壁 溶解物か $5 \mathrm{M}$ タンパク質の純化を行ない，その化 学的特性ならびに免疫化学的性状を明らかにした no 


$$
\begin{aligned}
& \text { ○下野 勉 (阪大・菌・保存) } \\
& \text { 小谷售三，加藤慶二郎，平地慶行（阪大・柬・細菌） }
\end{aligned}
$$

目的 Yoneda 5 ( $Z$ bl.Bakt.Paras itenk. Abt.A, 218 $: 80,1971)$ の記載に従って均等振燙培養して得 た菌令の揃った B C G 菌体から，その細胞表層構 築成分を「皮を制ぐ」よらに段階的に溶出するて とを試み，加溶出成分の抗原分析を行なった。 方法 B C G , 竹尾株を $1 \%$ Tween 80 一カザ ミノ酸培地飞 6 日間， $37{ }^{\circ} \mathrm{C}$ で均等振燙培養し， 定常期初期に達した菌体から，デターシェントに 上る抽出，機械的菌破壊，分別遠沈等の操作に上 り, 菌体成分特飞表層構築成分の抽出分離を企て た（図1）。得られた各画分についてゲル内沈降 反応に上り抗原分析を行ない，をてミノ酸，ア ミノ糖組成その他の化学性状を調へた。

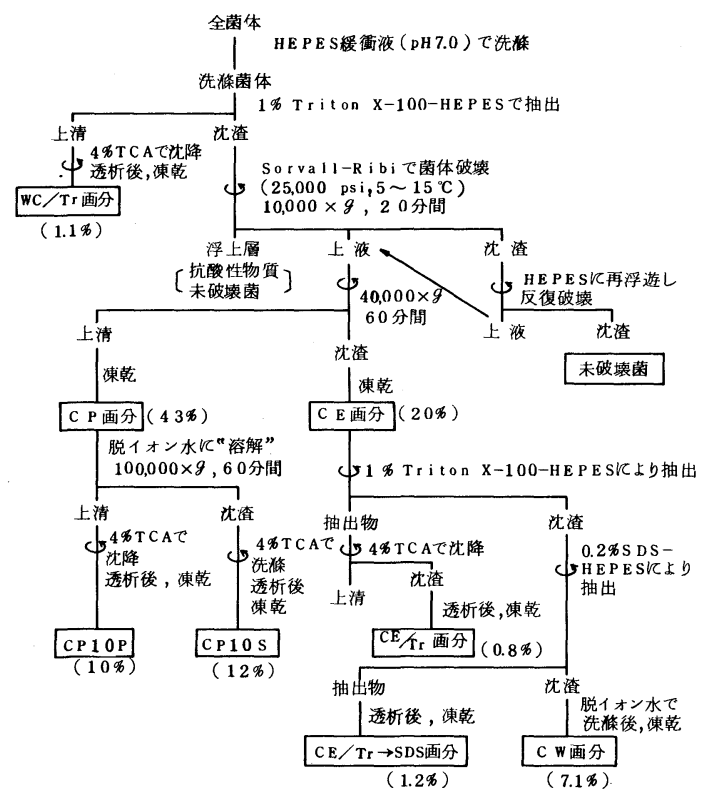

図 1 B C G 全菌体加らの細胞表層構築各成分ならびに細胞質画分 の分離操作

（）内の数字は出発全菌体 (乾燥量) 几対する収量を示す。 特に条件を示していない場合には， $3,000 \sim 5,000 \mathrm{~g}$ $20 \sim 30$ 分間の遠沈を示す。

結果 1. 均等振燙培養した若い細胞表面には 少なくとも 3 種類の抗原が存在し，振濞培養中に
培地中に遊離して行くこと，8〜9 日間以上培養 を続けると菌体内部の抗原が漏出するととが判った。

2. 未吸収抗 BCG血清ならびに全菌あるいは細 胞䇒で吸収した抗血清とのゲル内沈降反応を比べ ，また耐熱性やプロナーゼ消化に対する態度を調 ^, さらに Arabinogalactan(AG) pArabinomannan (AM)の標準品と比較を行った結果（図2），供試 BCGKは少なくとも，細䝭表面（WC/Tr，CULF）に 3 種，細胞壁 $[\mathrm{CW} / \mathrm{Tr}$ ( Son) $]$ 飞一種，細胞質膜 ( CE / $\operatorname{Tr}, \mathrm{CP1} 0 \mathrm{P})$ 画分K2 種, 細胞質 (CP10S) K1 種の それぞれの部分に特異な抗原が分布しているてと が明らかになった。また上述の細胞壁の抗原は AG であり，細胞質膜と細胞質との間で fuseする沈降 線を与えるのは AMであるてと（この沈降線を与え る抗体は AGと交叉反応を示すので, 細胞壁あるい は全菌吸収により血清中から除かれる)が判った。 3. 各画分の化学分析の結果, 破壊菌体を遠沈し て得た細胞表層画分をデタージェント処理により，プ ロテアーゼ処理を行うことなく，細胞壁を分離・

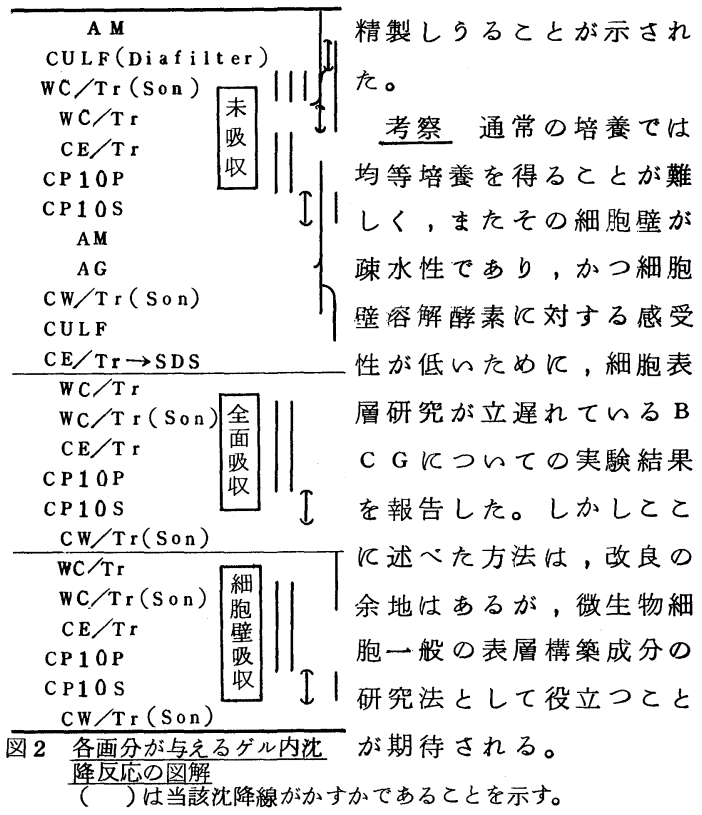


目的

1971 年Hofstad 壮人の歯垢加分離した Catenabacterium saburreum I 44 株の 菌体からトリプシン消化によつて血清学的に活 性のある多糖質抗原を抽出し，乙れの主要な棈 成因子がHeptoseと 0-acetylであるてとを 報告した。吾々は人の歯垢から分離される saburreum は菌体からFormamide-c抽出され る抗原によつて少くとも6つの血清型に分か れることを報告し、さらに，各血清型に属す る菌株からFormamide で抽出される粗抗原 の中性糖を分析した結果, Serotype 1, 2, お上び 3 亿属する菌株社何れすHeptoseを含 有しているが, Serotype 4, 5 および 6亿属 する菌侏からはHeptoseが検出されないこと を示し、C. saburreum は血清学的、Heptose(+)のGroup と Heptose (-) のGroup に大 別でをることを証明した。

そこでての度は,Heptose(+)のGroupに属 する3つの血清型の型特異性が何で決定され ているかを検討したのでその成績を報告する。 方法

$1 \%$ glucose 加 proteose pepton N.3 ブ イョンで 18 特間嫌気培盖した菌体にFormamideを加え $150 \mathrm{C}, 15$ 分加熱して粗抗原を 抽出した。乙の抗原には中性糖 (Phenol一硫 䟝法) の 2 倍加 3 倍量の蛋白(Folin 法) が含まれているので, Pronaseを加え 36 時 間消化した後，透析を行ない，唀析内液を Sephadex G - 100 0カラムでゲルク過を行 々，抗原活性分画をプールして Sepharose 6B のカラムで再度ゲル汇過を行つて精製した。 ゲル沪過で得られる各分画については中性糖 と蛋白の濃度を測定し, 同時にホモの抗血清 儿対する定量现降反応を行つて玾原活性を測 定した。ゲル沪過で得られた精製抗原飞 $1 \mathrm{~N}$
流酸を加え, $100^{\circ} \mathrm{C} 4$ 時間水解した後, Dowex 1 (醋酸型) とDowex50 ( H 型)のカラムを通し て中怗裾画分在得, メタノリシスを行い, 乾固, TMS化してカスクロで中性糖の検出, 定量を行 つた。

\section{結果および考察}

ゲル内沈降反応において抗 1 型血清に対し て反応する株はホモの1型抗原だけであつて 2 型および 3 型の抗原恃全く反応しない。抗 3 型血清は 1 . 型抗原と反応しないが, 2 型抗 原とは反応して明瞙な沈降線を生ずる。しか しこの沈降線はホモの 3 型沉原に上る沈降線 とは交叉する。したがつて Heptose(+)の group 炕属する 3 つの血清型の中， 1 型在 独立した抗原であり，2 型と 3 型壮類似の抗 原組成をもつと考えられた。Formamideで抽 出される粗抗原儿は, どの型の株から6Rha一 mnose,Galactose,GIucose およひHeptoseが検出されたが, Pronase 消化とゲル沪 過で精製した結果, 1 型抗原( FK 株)は. $\mathrm{He}$ ptose, 2 型抗原 ( OF 株) は Heptose の他保 Galactose が検出され, 3 型抗原 ( OS株) も Heptose とGalactose から樥成される ものであるてとが明らかとなつた。

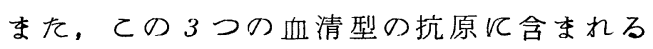
Heptose はレづれカスクロルおけ方保持 時間が问一であり（内部標準として加えたInositol r(対する相対保持時盟が 1.07 ( (相当), しかもGC-Mass のスペクトルも同一である ことから. Heptose の構造の違いがこの $3 つ$ の血清型の型特異性鼠係しているとは考えら れなかつた。なお，3つの血清型に属する精 製抗原には何れも Inositol 亿対する相対 保時間が 0.94 亿相当する不明の糖が微量で はあるが, 含有されていた。 


\section{C-I- 5}

血清学的 group A と groupE飞属するlactobacilliの抗原性状

○下憍博隆, 小平晋士, 住原泰雄 ( ヤクルト研究所)

目的 Lactobacillus helveticus と $\mathrm{L}$ 。

jugurti は血清学的 $\sqrt{ }$ group A V , L. bulgaricus, L。 lactis, L. brevis, L。 buchneriの 4 species group E隹している。 そして, group A 抗原は intracellular membrane 存在し，グリセロールテイコイ ン酸からなり，group E抗原は細胞壁のグ リセロールティコイン酸からなるとされて いる。しかし, groupA 抗原は, membran 抗原のため抽出されてくる抗原量が少なく, 抗原の抽出法を検討した。又, group EV V

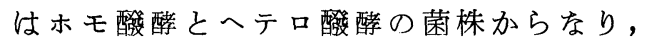
他の抗原の存在も考えられた。

細胞壁のティコイン酸以外の糖組成も検 討した。

方法 group A 抗原の抽出は, 全菌体 又は membrane 分画から $0,05 \mathrm{~N} \mathrm{HCl,} \mathrm{phenol,}$ $10 \%$ 冷トリクロル醋酸（TCA）を用いて行い, 抽出法を比較した。membran日の分画は, 菌 体を破壊した後, 細胞壁を除いたものから $30,000 \mathrm{rpm}, 2$ 時間の遠心で沈澱した沈澱 物を 2 回洗滌して得た。

血清学的 group EV属する菌株からの抗

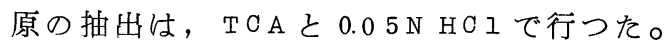

抗血清は, 全菌体を 600,1 時間加熱し て兔耳静脈に注射して作成した。抗原抗体 反応は，寒天ゲルと ring testによる沈降 反応で行つた。

糖組成の分析には, 中性糖はガスクロマト グラフイーを使用し，hexosamineに関しては Elson Morgan 法を用いた。

結果および考察 I. helveticusとL. jugurtiの数株を潠んで, 先ず group A 抗 原の抽出法を検討した。その結果, 全菌体

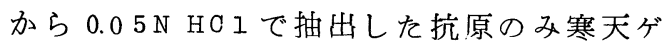
ル内で同一の沈降線を形成して反応した。
しかし, 全菌体から TCA phenol，68c，30分）で抽出したものとは 反応しなかつた。次に, membraneから稀塩 酸と冷 phenolで抽出した抗原は, 寒天ゲル 内では反応しなかつたが ring testでは反応

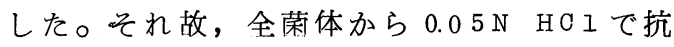
原を抽出し寒天ゲル内沈降反応で抗原性状 を調べたととろ，使用した全株から共通な 抗原が生じた。TCAで抽出したものには。 菌株に特有の抗原のみであつた。細胞壁の 糖組成は, 主に galactose hexosamineで あつた。

L. bulgaricus, L。 lactis, L。brevis;, I. buchneriの全菌体と細胞壁㘦 TOA 稀塩酸で抗原を抽出し寒天ゲル内で抗血清 と反応させた。先ず, TOA 抽出抗原では大 部分の菌株に同一の沈降線を形成して反応 する共通抗原があり，その他に，へテロ醱 醭の L. brevis と L。buchneriの全株とL. Iactisの一部の菌株飞反応し, 残りのさ。 lactisとL。bulgaricus の全株には応し ない抗原があつて, この2つの抗原は細胞壁 からも抽出されたし, 稀塩酸でも抽出された。 次に, 稀塩酸抽出では L.bulgaricusの全株 とTCA 抗原では反応しないL. lactisの菌 株にのみ反応する抗原があり，血清学的 group E は2つの subgroup 仿分けられる 可能性を示唆している。

細胞壁の糖組成は, galactos $\theta$, glucose, hexosamine (glucosamine of くは $\mathrm{N}$-acetyl glucosamine) からなつていたが, L。bul一 garicus にはglucoseが庄とんど含まれてい なかつた。

以上の抗原性状に関しては検討中である。 


\section{篠田 純男 - O岡本敬之介 (岡山大・薬・衛生化学 )} 三輪谷俊夫 (阪大・微研・細菌血清)

目的

腸炎ビブリオは極単毛性鞭毛菌と考えられてき たが，これを寒天平板上で低温培養すると極単毛 性鞭毛を生ずることが最近明らかになった。われ われはこの 2 種の鞭毛の精製を行ない, 両者の構 成単位が分子量は等しいが抗原性の互に異なる単 純タンパクであることを証明し報告した。ごのよ うに極単毛とは異なった周毛がどのような時に生 じ，如何なる役割を果しているかを知るために， 両鞭毛の生成条件を特異抗血清を用いて検討した。

方法

生じた鞭毛量の測定にはゲル内沈降反応を用い た。すなわちVibrio parahaemolyticus WP1 を各種の条件で培養し, 集菌後 $65{ }^{\circ} \mathrm{C}, 10$ 分 間加熱処理を行なう。この処理で鞭毛は f l lage $11 \mathrm{in} に$ 可溶化されるので遠沈して菌体を除き， 上清を用いて single diffusion 法により定量 沈降反応を行った。抗血清は既に報告した方法に より 2 種の flagellinを分離精製し,これを用 いてウサギを免疫して調製した。鞭毛の形態観察 には Le if son 染色による光学顕微鏡観察お よび電子顥微鏡観察を行なった。

\section{結果および考察}

腸炎ビブリオの極単毛性鞭毛は如何なる培養条 件でも観察され, 菌体当りの flagellin 量もほ ぼ一定であった。一方周毛性鞭毛の生成は培養条 件により大きく左右される。寒天平板培地を用い て培養すると多数の周毛が観察され,ゲル内沈降反 応でも周毛性鞭毛の f lagellin が検出されるが， 液体培地を用いた場合には静置培養でも振盪培養 でも周毛が観察されず, ゲル内沈降反応でもごく 微量しか検出されなかった。また培養上清中にも 周毛の f lagellin は証明されなかった。寒天濃 度を $0.5 \%$ 以上にして培養を行なうといずれも多
量の周毛を生成したが, polyacrylamide gel で培養すると周毛の生成量は少ない。したがって 固型培地ならば常に周毛を生成するとは結論でき ない。寒天平板上 $37{ }^{\circ} \mathrm{C}$ で培養を行なって顕微鏡 観察を行なうと培養初期には周毛性鞭毛が観察さ れるが，時間の経過と共に周毛は菌体から脱離し て極単毛性鞭毛のみが残存するようになる。これ をゲル内沈降反応で追跡すると, 培養開如後 9 時 間で増殖度は最高に達するが, 周毛量はその前

( $5 \sim 6$ 時間 )に最高に達し以後減少する。 25 ${ }^{\circ} \mathrm{C}$ で培養した時には増殖度, 周毛量共に $37{ }^{\circ} \mathrm{C}$ の 場合より遅れて増加するが, 対数増殖期に周毛生 成量が最高に達するという傾向は同じであった。 また $25{ }^{\circ} \mathrm{C}$ の場合には長時間培養しても周毛量の 減少は見られなかった。周毛の生成量が最高值を

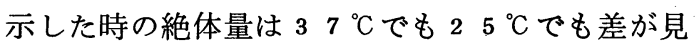
られなかった。したがって $37{ }^{\circ} \mathrm{C} て ゙$ 培養した時顕 微鏡で周毛が観察されにくいのは周毛の生成量が 少ないためではなく, 生成した周毛が容易に菌体 から脱離して代謝分解されるためと考元られる。 寒天平板培地に glucose を添加して $25{ }^{\circ} \mathrm{C} 1$ 夜 培養すると周毛の生成量は glucose 無添加に加 べて非常に少ない。この時培地の $\mathrm{pH}$ を測定する とglucose 添加の場合には代謝により生じた酸の ために $\mathrm{pH}$ 4.7〜4.9 であるが, 無添加培地の $\mathrm{pH}$ は 7.7〜7.9 であった。培養をさらに続けると gluー cose 無添加培地の周毛量は変動しないが, glucose 添加培地の周毛量は次第に増加する傾向 を示した。また培地に Tris (hydroxymethyl) aminomethane を加えて緩衝力を増して培養す ると, glucose添加による $\mathrm{pH}$ の低下が少なく， 周毛生成量も無添加の場合に近い值を示した。し たがって培地の $\mathrm{pH}$ の低下が周毛の生成を抑制す ると考えられる。 
C-I-7

迅速発育性ミコバクテリアのリボリーし構成タンパク分子種の比較分析

○川口久美子. 左司 宏(兵庫医大·細菌). 森 竜男 . 伊藤 利根太郎 (阪大微研)

\section{目的}

タンパク質合成の場としてのリボッーしは bacteria の種によらず一定の大きさと約 60 個 の構成蛋白分子種からなり,多くの cistron に 対応する複合形質としての可能性を光なえてお り，遗伝子 homologyをよく反映しうると考えら れる。我々はミコバクテリアに於ける近緣関係 及び系統発生的関連について更に分子レベルで の知見を得るためにりボッーしの構成蛋白分子 種を種々の菌株について比較することを試みて いる。今回は rapid grower, いわゆる Runyon の第 4 group に属する数種の菌株の構成蛋白分 子種について比較分析を試み, 現在までに得ら れた結果を報告する。

\section{方 法}

リボソーし構成蛋白分子種の比較分析は, 大 鹰らの開発したカルボキシメチルセルローズ ( C M C ) 力ラムクロマトグラフィーによる分 析方法を用いた。referenceとして今回は主に M.smegmatis A T C C 14468 を使用し Sauton 培 地中で振盪培養を行なって ${ }^{14} \mathrm{C}$-Lysineをとり こませ,また比較すべき他のstrainには同様に して ${ }^{3} \mathrm{H}$-Lysineをとりこませた後, 光れ光れの 菌からリボソーしを50 s，30 s 要粒子に分離 調整し, 双方の亜粒子どおしを $6 \mathrm{M}$ urea 中で混 合して C M C カラしに同時に吸着させ, 溶離を 行なういわゆるコクロマトグラフィーを行なっ た。溶出は $0.03 \sim 0.5 \mathrm{M}$ a cetate buffer を用 い約 300 本の tube に分画し, ${ }^{3} \mathrm{H}$ と ${ }^{14} \mathrm{C}$ の力ウン トのパターンを比較して両株のリボッーし構成 蛋白分子種の差異を検討した。

\section{結果及び考察}

比較に用いた菌株はM.smegmatis， 6 株 (A T C C 14468, lacticola, rabinowitchi, jucho, 607 おび butyricum N C T C 333）と M.phlei,

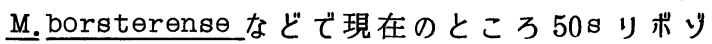

一ムに関しては, ATCC 14468 とlacticola それ に rabinowitchiはほぼ一致した溶出パターンを 示し, 同じ構成蛋白分子種を有していることが わかった。 juchoはこれらの菌と比べて, 溶出 パターンとして識別可能な 19 peaks のうち 2 peaks に差異が認められ，607はこれらのほ かに更に 1 peakの差異を示した。butyricumは ATCC 14468 と比較した場合, jucho 607 とはこ となる 4 つの peakに差異が認められた。お比ら く关れ艺れの peakに相当する構成蛋白分子種の アミノ酸組成のちがいを反映しているものと思 われる。 speciesを異にする $\mathrm{M}$. phleiや

M. borstelense との間には, 対応づけの可能な peak は見出されず, 殆んど共通構成蛋白分子種 淰ないものと判断された。ミコバクテリアに於 ける今回のリボッーム蛋白の分析結果は, きわ めて鋭敏に菌株間の差異を示し，近縁関係を解 析する上に有用である知見を提供しうることを 示している。また上述の結果から導びかれる株 間の近縁関係は, 徳永らによって遺伝的組み換 えが可能な接合の適合性の性質として報告され ている近很関係と極めてよく一致している。さ らにstrain 間, species 間にみられた大幅なち がいは, 大沢らが腸内細菌科に属する strain 間, species 間更にはgenus間にかなりの共通構 成蛋白成分をみとめているのとは全く様相を異 にしており，このことはミコバクテリアに於け る生育環境条件のちがいや独得の遺伝的性質に 由来するこの菌の進化コースに於ける特異性を 反映しているように考えられる。 
C-I-8 ソンネ型赤浰菌100052株の産生するコりシンの精製について

○松口来行、武谷健二（九大、医、微生物） 天胃和暢（福岡大、医、細菌）

且的 ソンネ型赤疮菌100052株は、同種の100033 株なとの発育を阻止するコりシンを应 生する。前回、われわれはこのコンシンを ある程度精製して、をれが形態学的に直径 8nmのリンク状㥏造をもつ粒子てあろろと 報告した。しかしアクリルアミトゲル㫣気 泳助ては単一のハントを作らず、十分には 精慗をれていないことが明らかとなったの て、今回糟製法を検时し、均尓なコリシン 標本を得るために实験をおこなった。

\section{方法}

コリシン産生菌としてンンネ型赤病菌 100052 株と、指示菌には同100033株を用 いた。

増菌培地としてイーストエキス0. $5 \%$

を加えだプトン水を用いた。

対数增殖期の菌液 1しあたり $0.5 \mathrm{mg} の マ イ$ トマイシンCを加えて锈発をかけ、をらに 5時間培賸を綂けたのち、ク口ロホルムを 滴下し低速速心上清をとってこれを精製 の材料とした。

精製は以下の順序ておこなった。硫酸 アンモニアによる分画䜖析、超速心分離、 木ス木セルロースカラムクロマトグラフ イー、壏化セシウム密度こう配超逞心分 踓。

活性の定是は的 $3 \times 10^{8}$ 個の指示圈を軟

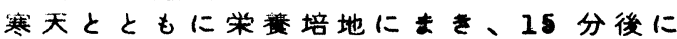
コリシン液を1滴スポットして37C 3 時 间塔症ののち、增殖を阻止した最大希釈 漉度て決定した。

\section{結果および考祭}

水冷した粗上清に、硫酸アンモニアの 乾燥粉末を徐々に加えてかくはんし、30 $\% 、 60 \% 、 75 \% 、 100 \%$ ステップて分迪 塭析をおこなった。それぞれの遠心沈殿 を、 $0.05 \mathrm{M} ト$ 塩酸緩衙液 $\mathrm{pH7} .8$ て スペントして透析すると、大部分の活性 は0ー30\%の画分て回収された。

やた触白色をおひていたこのフラクシ ヨンは、その後 $50,000 \times g 2$ 時閒の超遠 心て沈殿を生じ、コッシン活性部分は上 清に残ってほほ無色透明となった。
この部分をホスホセルロースカラム（ 内徍 $9 \mathrm{~mm}$ 、最さ $5.8 \mathrm{~cm} 、 0.01 \mathrm{M}$ リン酸カリ ウム緩銜液 $\mathrm{pH} 6.5$ ) に道すと、総タンバ 18mgの試料は吸揞される部分は少なく、 活とんと菜通りして出てきた。活性の最 も高い部分の280nmにおける吸光度を测定. したところ、吸収極大は280nm、極小は $255 \mathrm{~nm} 、 260 \mathrm{~nm}$ の吸収に対する280nmの吸収 は1。㢩上て、この橴本は核醌成分の混入 をほとと除外しうるねンハクのフラク ションてあると涍られる。

次にこの試料を塭化セシウム密度こう 配超逶心にかけた。比重1.5-1.3-1.1

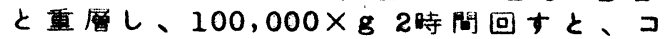
リシン活性は比重1.05から1.250間に あり、他に1.28 付近に薄いハントを生 したが、このハンドは活性はなかった。 粗上清にくらへていなり精製てをたこ のコリシンについて、をらなる精製とコ リシンの存在形態に関する㭘榇をおこな っている。 


\section{C-I-9}

Lactobacillus acidophilus ATCC 4357 の産生するバクテリオシン

\section{松尾吉恭・宇都宮節夫（広大・医・細菌）}

\section{目的}

L. acidophilus ATCC 4357 が数種の乳酸杆菌 中, L. bulgaricus ATCC 11842 に対して活性を示 すバクテリオシンを産生するので，その性状を 検討する。

方法

用いた菌は乳酸杆菌 9 株 (L. casei 4 株， L. plantarum 2 株、L. bulgaricus, L. salivarius, L. acidophilus 各 1 株) とヒト，動物および自然界から 分離された腸球菌 122 株。培地はILS 培地。バク テリオシンの活性は通常, ILS 液体培地 48 時間 培養の培養上清またはその $50 \%$ 硫安飽和分画の透 析内液について測定した。

その物理化学的性状は温度抵抗性 (沸騰水浴上 10 分および高圧滅菌 20 分), 紫外線抵抗性 (東 芝殺菌ランプ GL 15, 距離 $25 \mathrm{~cm}, 2$ 時間), $\mathrm{pH}$ 安 定性 $(2.6 \sim 11.0)$, 有機溶媒処理抵抗性 (エチルエ ーテル, 石油エーテル, アセトン, 四塩化炭素, クロロホルム。各 $37^{\circ} \mathrm{C}, 30$ 分), 尿素抵抗性 $(6$ $\mathrm{M}, 37^{\circ} \mathrm{C}, 20$ 時間), 抗蛋白分解酵素性 (トリプ シンおよびプロナーゼ， $0.2 \mathrm{mg} / \mathrm{ml}, \quad 37^{\circ} \mathrm{C}, \quad 1$ 時 間)，抗核酸分解酵素性 DNase および RNase，同 上）の諸点について検討した。

\section{結果}

L. acidophilus ATCC 4357 の産生するバクテ リオシンは供試乳酸杆菌中 L. bulgaricus ATCC 11842 に対してのみ活性であり, 他方, L. bulgaricus は L. acidophilus のほか L. casei IAM 1043, 同 IAM 1045, 同 S-1 および L. plantarum NCTC 7220 の培養上清または菌体抽出液 （久保田 $200 \mathrm{M}$ 超音波発生装置，200W, 45 分処 理）のいずれか，または双方に対して感受性であ った。

L. acidophilus の対数増殖期の培養液にマイト マイシン $\mathrm{C}$ を $0.1 \mathrm{mcg} / \mathrm{ml}$ の最低濃度から種々の 濃度に加えても, またその洗浄菌に紫外線を 5
120 秒照射したのち培養しても，バクテリオシン の産生は增強されなかった。

L.acidophilus のバクテリオシン活性は菌体の 超音波抽出液中には証明されず, ILS 培養上清中 にあって, 50,000 回転, 90 分の遠心でおちてて ない低分子物質であった。てれは L. bulgaricus に速やかに吸着して，おそくとも20 分までに殺 菌的にはたらくが，位相差鏡検による逐時的観察 ならびに走査電顕所見によると，菌体表層の形態 学的変化は全く認められなかった。

バクテリオシンの物理化学的性状は以下のよう であった。熱, 紫外線, $\mathrm{pH}$ 亿安定で, DNase お よび RNase では活性を失わなかったが，トリプ シンおよびプロナーゼでは不活化された。クロロ ホルムにはかなりの感受性を示したが，供試した その他の薬剤には安定であった。バクテリオシン はエチルアルコール沈溉性であるが，エチルエー テルやアセトン中には移行しなかった。

腸球菌のなかに，てのバクテリオシン感受性の ものが存在し，また腸球菌の産生物質のなかに L. bulgaricusの增殖を阻止するもののあるととが認 められた。

\section{考察}

L. acidophilus ATCC 4357 の産生するバクテ リオシンは Bradley のいう熱に安定でトリプシ ンで失活し，分子量が小さく電子顕微鏡でみえな い群に存するものと考えられる。腸球菌のなかに これに対する感受性菌が存在することはその分類 学的位置から興味深い。 


\section{C-1-10}

Rhodochrous 群の産生するバクテリオシンに関する研究（第 1 報）

齐藤 肇, 清谷克寛 $($ 広大・医・細菌)

且的

末だ分類学的位置の確立されていない, 恐らく はgenus Mycobacterium と genus Nocardia との中間に位する, Rhodochrous 群 (genus Gordona, Tsukamura 1971)の菌株が バクテリオシンを産生するととを見出したので, その性状を明らかにし，またてれによる本菌群の 分類をこてろみる。

方法

バクテリオシンの産生条件およびその性状の検討 には, $0.1 \%$ Tween 80 および $4 \%$ グリセリンを加えた ハートインフュージョン寒天培地 (HIA)の基底層上に, 指示菌として ATCC 14348株の $10^{7} コ の$ 細胞を含む半 流動 HIA を重層し，コルクボーラーで直径 $8 \mathrm{~mm}$ の穴 をあける。乙れに諸条件下での ATCC 4001 株の 4\% グリセリンブイヨン培養液の遠沈上清をクロロホル ム処理したもの, あるいはてれを $60 \%$ 飽和硫安沈 澱および $80 \%$ アルコール沈澱によってえられた沈 渣の $0.1 \mathrm{M}$ 燐酸緩衝液 ( $\mathrm{pH} 7.0$ ) 飞よる $1,000 \mathrm{mcg} / \mathrm{ml}$ 液の $0.05 \mathrm{ml}$ 入れ, $37^{\circ} \mathrm{C}, 18$ 時間培養後にみら れる阻止円の直径を計測する。

バクテリオシン型別は, 束村博士 (国療中部病院) より分与をうけた Rhodochrous 群 (Gordona) の 4 菌種 56 株 - G. bronchialis 19 株, G. terrae 14 株, G. rubropertincta 19 株および G. aurantiaca 4 株一について，指 示菌として Rhodochrous 群菌 54 株, Nocardia 6 菌種 32 株および VI 群非定型抗酸菌 14 菌種 108 株を用 いて武谷らのマイコバクテリオシン 型別法に準じて 検討した。

バクテリオシン精製の 1 つのとてろみとして,ATCC 4001 株を 4\%グリセリン加 ハートインフュージョン ブイヨン (HIB) 中で $37^{\circ} \mathrm{C}, 7$ 日振盪培養し, その低 速遠沈上清より $60 \%$ 飽和硫安によって沈渣をとり, DEAE-cellulose, Ecteola-cellulose および Sephadex G-100 各カラムクロマトグラフィー の組合せによるカ法を おてなった。

結果および考察
ATCC 4001 株のHIB 中でのバクテリオシンの産生 はTween 80 非含有培養液中で振盪培養した場合が

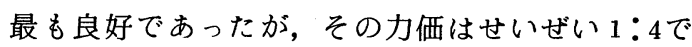
あり, 現在より高い力価の標本をうる方法につい て検討中であるる。本物質は Nutrient broth (Difco) では 産生がみられず, ブレイン HIB での産生は HIB に おけるそれよりも多少とも優っているようであっ たが，乙れら両者の力価には差はみられなかった。 粗標本についての検討では, 本物質は水溶性, 醋酸エチールおよびブタノールに不溶性, pH 2-8 で安定, $60^{\circ} \mathrm{C}, 30$ 分わよび $100^{\circ} \mathrm{C}, 5$ 分の加熱に は $\mathrm{pH} 2$ で不安定, $\mathrm{pH} 4 \sim 8$ で安定, 活性炭に被吸 着性, 非透析性, 50〜60\%硫安および $80 \%$ アルコ ールで沈澱, クロロホルム処理に安定, $\operatorname{trypsin}(1.25$ $\mathrm{mg} / \mathrm{ml})$, papain $(1.25 \mathrm{mg} / \mathrm{ml})$, pepsin $(2.5 \mathrm{mg} / \mathrm{ml})$, および $\alpha$-chymotrypsin $(2.5 \mathrm{mg} / \mathrm{ml})$ の 30 分処理で失活, DNase $(0.2 \mathrm{mg} / \mathrm{ml})$ および RNase $(0.2 \mathrm{mg} / \mathrm{ml})$ の 1 時間処理に 安定,であり蛋白性のものであるととが示唆された。

Gordona 94 菌種の鑑別乃至同定上多少とも参考 とはなりうるが，てれを clear-cut になしうる満足す べき指示菌は Gordona および Nocardia の菌株のなか には末だ見出されていない。他方，IN群抗酸菌中 Mycobacterium fortuitum, M. smegnatis および M. phlei の数菌株は G. aurantiaca の産生するバクテリオシン に高い感受性を示し, なかんずくM. phlei Wa-366 又 は M. vaccae ATCC 15483 を指示菌とするととにより G. aurantiaca を G. bronchialis, G. terrae, および 'G. rubropertincta から明確に鑑別できたが，後 3 者間のそれ は不能であった。如上の成績は Gordona の産生する バクテリオシンに感受性を示す宿主の極めて少ない ととを示唆しているものと思われる。

ATCC 4001 株の産生したバクテリオシンは上記の方法 である程度精製された標本をうるてとがでさたが，末 だその収量は少なく且紫外線吸収と活性との完全 な一致がみられておらず，本物質の精製法につい てはなお今後の課題である。 
D-I- I

黄色ブドウ球菌及び肺炎桿菌の砒素耐性について

慈恵医大、医、第二細菌

○石川友章、中原英臣、近藤勇

\section{(I) 目 的}

臨床分離の黄色ブドウ球菌（以下黄色ブ菌と略 す）の多くは多剂耐性と同時飞重金属耐性をも つことが知られている。この耐性の多くは 細胞 質内に存在するplasmid により支配されているこ とは衆知の事実である。一方、腸内細菌の $\mathrm{R}$ 因 子についても 薬剤ばかりでなく $\mathrm{Hg}, \mathrm{Co}, \mathrm{Ni}$ な どの金属イオン耐性が存在することが報告されて いる。

われわれは 第 30,32 回本学会関東支部総会で 黄色ブ菌、大腸菌、肺炎桿菌、緑膿菌に扣ける重 金属耐性分布について報告した。この中で黄色ブ 菌及び肺炎桿菌の砒素に対する耐性菌は各々 46. $5 \% 、 80.2 \%$ の頻度であり、肺炎桿菌飞も高頻度 で砒素耐性が存在することを明らかにした。

今回は黄色ブ菌のplasmid 支配による砒素耐性 機構と肺炎桿菌の砒素耐性機構とを比較検討し、 若干の知見を得たのでここに報告する。

(II) 材料及び方法

菌株：黄色ブ菌は 教室保存株 248 系 $\beta \mathrm{H}$. Pcase plasmid 保有株及び非保有株 (以下 $\mathrm{Pc}^{\mathrm{R}} \mathrm{Pc}^{\mathrm{S}}$ 株と略す）を用いた。肺炎桿菌については、JK76 株（以下 $\mathrm{As}^{\mathrm{R}}$ ) 及びこれから Acridine orange 処理によって得られた砒素感受性 (以下 $\mathrm{As}^{\mathrm{s}}$ )の 2 株を用いた。重金属耐性試験は平板寒天による 稀釈法を用い砒酸塩及び亜砒酸塩について行った。 (iii) 結 果

1) 砒酸塩、亜砒酸塩飞対しての黄色ブ菌及び

\begin{tabular}{c|c|c|c}
\hline Species & Strain & $\mathrm{Na}_{2} \mathrm{HAs}_{4}$ & $\mathrm{NaAsO}_{2}$ \\
\hline \multirow{2}{*}{ Staph. } & $\mathrm{PC}^{\mathrm{R}}$ & 800 & 100 \\
\cline { 2 - 4 } & $\mathrm{PC}^{\mathrm{S}}$ & 100 & 10 \\
\hline \multirow{2}{*}{ Kleb. } & $\mathrm{As}^{\mathrm{R}}$ & 1600 & 500 \\
\cline { 2 - 4 } & $\mathrm{As}^{\mathrm{S}}$ & 100 & 10 \\
\hline \multicolumn{3}{|c}{$(\mathrm{mcg} / \mathrm{ml})$}
\end{tabular}

肺炎桿菌の耐性值は、2 4 時間で下表の如くである。

2) 両菌種共飞、塩添加培地中に打ける増殖曲 線は 黄色ブ菌の $\mathrm{HgCl}_{2}$ 加培地でみられる特有の $\mathrm{V}$ 字型パターンは示さなかった。

3）両菌種に対する砒素の毒性は 致死効果と しては 即時的に発現しないことも、黄色ブ菌の $\mathrm{Hg}$ 耐性機構のカテゴリーに属さない様に考えら れる。

4) $4{ }^{\circ} \mathrm{C}$ の低温下での砒素イオン添加培地中に 扣ける両菌種共に生菌数の減少はほとんどみられ なかった。これは、黄色ブ菌の $\mathrm{Cd}$ 耐性機構のカ テゴリーに近似するものと考えられる。

5）塩添加培地飞 g lucose を共存させると黄色 ブ菌 $\mathrm{Pc}^{\mathrm{R}}$ 株及び肺炎桿菌 $\mathrm{As}^{\mathrm{R}}$ 株では 耐性の表現 飞顕著な差を生ずるが、これがどの様な機構上の 差異により生ずるかは、現在な扔検討中である。

(IV) 考 察

現在、砒酸、亜碓酸両塩飞対する耐性に関して は、黄色ブ菌のPcase plasmid亿ついてNovick らの報告があるが、肺炎桿菌については、未だそ の報告をみない。肺炎桿菌に関してこの砒素耐 性はR 因子と別個飞存在するらしく、cell contact飞よってその耐性の伝達は得られていな い。アクリジン系色素で、その耐性が脱落するこ とから、恐らく plasmid like のものであらうと 考えているが現在検討中である。又、これら 2 菌 種にみられる砒素耐性の機構が、黄色ブ菌で示し た2つのカテゴリー（J.Bact。1974）のどちら に入るかは、砒素の菌体内取りの有無を検べるこ とにより判定が可能であるので、現在検討中であ る。

黄色ブ菌と肺炎桿菌の耐性の発現に関して glucose の存在により全く異なった動能を示すこ とは大変興味深いことである。 
栗山義明, $\bigcirc$ 大屋 哲, 山本光世, 菅原真一 (三共中研 - 細菌 )

目的

我々はペニシリン ( PC), セファロスポリン $(\mathrm{CS})$ 耐性の種々のProteus 属臨床分離株の $\beta-l a c t a-$ mase について, 酵素学的, 蛋白化学的, 血清学 的方法で,その性状を明らかにし, 相互に比較検 討を進めている。Proteus morganii 1510の $\beta$-lactamase の精製, 若干の性質についてはす でに報告した。（生化学年，413(1974））この 酵素は PC 類及び C S 類の両方を基質とし得るが C S 類に対する活性の方がより強い酵素であった。 今回は $\mathrm{PC}-\mathrm{G}, \mathrm{AB}-\mathrm{PC}$ を殆んど水解しない明ら かにセフォロスポリナーゼ ( C S ase) 型の $\beta$ lactamase をProteus rettgeri 1602より分離 精製して，その性質について検討したので，先の 酵素で得られた結果と比較し報告する。

\section{方法}

酵素活性は, PC 類を基質にした場合はPerret のヨード法で， CS 類を基質にした場合は紫外部 吸光度の変化から求めた。 PC, CS 高度耐性の臨 床分離株P.rettgeri 1602 をハート・インヒュ 一ジョン・ブィョン培地で培養し, 培養開始後1.5 時間と 25 時間目にインデューサーとして $6-\mathrm{APA}$ を加え（各々 $25 \gamma / m \ell ）$,さらに1.5時間培養して集 菌した。

酵素の精製は得られた囷体の超音波破砕液の遠 心上清を DEAE一セルロース, CM-セファデッ クス, ハイドロキシルアパタイト, セファデック ス G-75 のカラムクロマトグラフィーを用いて行 い, ディスク電気泳動で単一バンドとなる標品を 得た。この方法により超音波破砕液に比べ比活性 が 200 倍以上に上昇した。

\footnotetext{
結果と考察

P. rettgeri 1602 株の $\beta$-lactama $s e$ はペニシリナーゼ活性の非常に弱いCSase 型
}

の酵素であるが，酵素の誘導には 7-ACA， CET よりも 6-APA, PC-GなどのPC類の方がより 有効であった。

精製酵素の至適 $\mathrm{pH}$ は 8.0 , 至適温度は約 $50{ }^{\circ} \mathrm{C}$, 分子量はセファデックス G-100 カラムクロマト グラフィー及び S D Sーポリアクリルアミドゲル電 気泳動で 40,000 であった。これらの性質について は先に報告したP. morganii の酵素とよく似てい る。しかしこの酵素の等電点は $\mathrm{pH} 8.7$ で塩基性の 蚠白であること, 基質特異性に関して PC類に対 する活性が非常に低いことなどが先に報告した P. morganii の酵素と異なり, さらにP. morganiiの $\beta$-lactamase に対して作ったウサギの抗血 清はこの酵素と反応しない。酵素の性質のこのよ うな異同がどのような分子的な機作によるかとい つた点については今後検討していく予定である。 な打 CSの 7 位がメトキシル化された誘導体は一 般に $\beta$-lactamase に抵抗性があることが知られ ているが，その一誘導体であるセフォキシチン ( CFX) はこの酵素に対しても強い抵抗性を示し さらにCER P CETのこの酵素による水解に対し て強い拮抗阻害刘になることがわかった。 ( $\mathrm{CER}$ に対する $\mathrm{Km}=7.2 \times 1 \overline{0}^{4} \mathrm{M}, \mathrm{CFX} \mathrm{Ki}=$ $5.7 \times 10^{-7} \mathrm{M}$ ) 
緑膿菌の生産する penicillinaseについて

○田井賢、沢田 洋介、伊予部志津子、三橋 進 （群大医・微生物）

\section{目的}

Ps. aeruginosa感染症飞有効な penicillin 系薬荗としては、主にcarbenicillin(OPC)が用 いられてきた。従つて、今日OPOK対して高度 耐性の株が高頻度で分離されている。このような 耐性の機構としては、主にßーlactamaseによる ○一lactam環の開裂が考えられる。そこで、われ われはこれら C P O 耐性株の $\beta$ - lactamaseの性 質について検討した。

材料と方法

病巣由来のPs.aeruginosaを用いた。酵素は普 通ブイヨンで振盪培養して得られた菌体を、超音 波破砕して調製した。酵素活性は、Perret のヨ 一ド滴定法により測定した。

結果

病巣由来 Ps.aeruginosa 5 ち $400 \mathrm{mcg} / \mathrm{m} \ell$ 以 上の C P O 耐性を示す28株について、その及一 lactamase活性を調べたところ、いずれも活性が 検出された。これらの队一lactamaseは、その基 質特異性を調べた結果、いずれもpenicillinase の性質を持ち、次の 3 種類に分類された。

すなわち. C P C と P C Gを同程度加水分解す るもの17株（グループ1）、ＣＰＣをＰＣの約 $\frac{1}{\Gamma}$ しか加水分解しないもの8株（グループ2）、 C P C を P C G の約 2.5 倍加水分解する の 3 株 (グループろ)であつた。これらろ種のß一 lactamaseの酵素的性質を調べるために、O P O 耐性の伝達可能な株をそれぞれ一株づつ選び代表 株とし、同一の宿主菌に伝達し。今-lactamase をDEAE Sephadex OM Sephadex によるイオン交 換、Sephadex G75によるゲルろ過、及びElectrofocusing によつて約 300〜800倍に精製した。精 製した $\beta$ - Iactamaseについて、至適 $\mathrm{pH}$ 、至適 温度、阻害剤による影響を調へ、分子量を測定し た。その結果、これらの性質に扣いて、 3 種の队 一 lactamaseは異つており、特にグループ 3 のß
ー lactamase は他の 2 種と非常に異つていた。 考察

Ps. a eruginosaの C P C 耐性株のß-Iactamase はその基質特異性及び、酵素的性質によつて3種 類に分類された。この内、グループ 2 のー lactamaseは、Sawaietal(1969)の報告した、 FinterobacteriaceaeのI型令- lactamase、及 び Sykes and Richmond(1970)の報告した、Ps. aeruginosa RP1の $\beta$-lactamaseとその基質特 異性が非常に似ているので、同じ種類の酵素であ ると思われる。一方、他の 2 種は、今まで報告の ない新しい型の及一lactamaseであると思われる。 


\section{$D-1-4$}

コレラ菌から得られた $\mathrm{R}$ 因子の遺伝学的性質と耐性形質の適応的発現

○横田 健, 萩原純子(順天堂大・医・細菌)

桑原章吾, ( 東邦大・医・微生物)

目的

桑原らは1 1962 年 $\mathrm{R}$ 因子が赤痢菌, 大腸菌か らコレラ菌に伝達し得るととを見出し,つぶいて 患者分離の耐性コレラ菌からR因子を得た。しか しコレラ菌におけるR因子の研究は実験手技が簡 単でないため，追試が容易でなく，1９７７０年頃 にはコレラ菌の多剤耐性の原因としてのR因子の 存在に疑いを抱く研究者もでている。演者らは 1969 年大腸菌からコレラ菌へのR 因子伝達を 再確認するとともに温度感受性RtsI 因子が例外 的に低温でコレラ菌内に安定に保持されるととを 見出した。的 1974 年患者分離の耐性コレラ 菌から温度感受性R因子，VRT を見つけるととが でをた。本研究の目的はてのVRI因子と，RtsI 因子の遺伝的類縁関係をしらべるとともに。VRI 因子の Chloramphenicol (CM) 耐性形質の発現が 適応的であるととを発見したので，そのCM不活 化酵素の産生調節機構を他の $\mathrm{R}$ 因子のそれと比較 研究するととにある。

方法

VRI因子の fi型はこのR 因子をもつ E.coli， Hfr, RI/VRI 染色体供与菌とした時の染色体組 み換え頻度と， $\mathrm{F}$ 線毛吸着ファージに対する感受 性から検討した。またDattaらによる相互排除試 験 (compatibility test)からVRI因子がRtsI 因子と同一のグループに属するものかどらかしら ベた。

VRI因子の C M 耐性形質の適応性は E.coli $\mathrm{CSH} 2$ (naI)/VRI , AB 1 157/VRI, RI/VRI等を So dium lactateを糖源としたM 9 最小液体培地で 培養したのち，乙れに最小発育阻止濃度 (MIC) 以下の種々の濃度の C M $5 \sim 120$ 分接触させ て C M 耐性上昇の度合を液体培地稀釈法でしらべ た。さらにこのR因子をサイクリック A M P 欠落 変異菌であるE.coli GPI(cya), CA7902(cya), Salmonella typhimurium GP8 (cya) に入れた

時の耐性度の変化, C M 不活化酵素産生量の変動 などから， R因子の適応的耐性形質発現とサイク リック A M P の関係を追及する実験も計画してん る。

\section{結果および考察}

V R I 因子はすでに報告した通りその伝達性は 温度感受性であるがRts1 やYR5因子と異なり， 高温 $(42 \mathrm{C}$ ) でも安定にコレラ菌や大腸菌中に存 在し得る。そのfi型はRtsI 因子同様陰性である。 Dattaの群別標準株との重感染時における伝達率 低下と相互排除は下表に示した通りで,VRI 因子

\begin{tabular}{|c|c|c|c|}
\hline $\mathrm{R}$ 因子 & 群 & 伝達率低下 & 相互排除 \\
\hline R386 & FI & + & - \\
\hline R16 & 0 & + & - \\
\hline R 124 & FN & + & - \\
\hline R 391 & $\mathrm{~J}$ & - & + \\
\hline Rtsl & $\mathrm{T}$ & + & - \\
\hline R4466 & $\mathrm{M}$ & + & \pm \\
\hline R 144 & $I \alpha$ & - & - \\
\hline R621a & Ir & + & - \\
\hline $\mathrm{N} 3$ & $\mathrm{~N}$ & + & \pm \\
\hline R 217 & $\mathrm{H}$ & - & \pm \\
\hline R4 $0 a$ & $\mathrm{C}$ & - & - \\
\hline RP 4 & $P$ & - & - \\
\hline RA 1 & A & 二 & - \\
\hline R471a & $\mathrm{L}$ & - & \pm \\
\hline R387 & $\mathrm{K}$ & 未 検 & 未 検 \\
\hline R 478 & $S$ & 11 & II \\
\hline $\mathrm{R}_{1}$ & FII & 11 & "I \\
\hline$s-a$ & $\mathrm{~W}$ & "I & "I \\
\hline
\end{tabular}

\pm ：一方のみ低頻度に脱落

ると考えられた。

VRI因子飞よって支配されるC M 耐性形質は MICの 50 分の 1 の微量のC M と接触させるとと にょり, その $\mathrm{C} M$ 耐性度は 120 分以内に $2 \sim 4$ 倍 上昇した。現在この場合のCM - acetyltransferase 産生量の変化を基質量およびサイクリック A M P との関連飞おいて研究中である。 
目的

メノマイシンは西独へキスト社で開発された燐 を含んだ糖脂質からなる抗生物質で、グラム陽性 菌に優れた抗菌力をるつ。われわれはすでに、乙 れが腸内細菌で R因子などのプラスミドをるつ菌 に強い抗菌力を示すととを見いだし、メノマイシ ン感受性がプラスミドの伝達機能と関係するてと を示した。今報では、伝達機能に関与する遺伝子 の解折が十分なされている F因子を用いて、伝達 機能とメノマイシン感受性の関係を再検討した結 果を報告し、メノマイシン感受性の物質的本体を 考察した。

材料和よび方法

大脂菌 K-12株の亜株: JC3272 株で、伝達遺 伝子に欠損をるつ変異 $\mathrm{F}^{\prime}$ 因子: $\mathrm{F}_{42}-\mathrm{lac}$ をつる のを用いた。乙れらの株は西独マックスプランク 研究社 Actman 博士より分与を受けた。乙れらの 株のメノマイシン感受性は、濃度の異なるメノマ イシンを含むB T B 孚糖加普通寒天平板に、各菌 株の対数增殖期細胞、約 1000 個をプレートム $37^{\circ}$ $\mathrm{C}$ 一夜培盖后の出現集落数による生残曲線によっ て検討した。なお、変異 $\mathrm{F}^{\prime}$ 因子の存在は、使用直 前に、乳糖分解性および各種特異性フォージ感受 性によって碓認した。下にWilletts \& Actman よるF因子の伝達遺伝子の地図を示す。

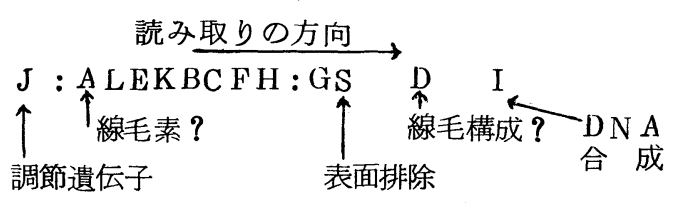

ここで、J 遺伝子の産物が $\mathrm{A} \rightarrow \mathrm{I}$ への遺伝子の $\mathrm{m}$-RNA への転写の調節をするレプレッサーであ るとと、S 遺伝子の産物が表面排除に関与するて とがWilletts \&Actman によって示されている。 また I 遺伝子欠損株が $\mathrm{F}^{+}$アージの增殖をゆるす ととから、との遺伝子は伝達に関与するD N A 合 成機能と考えられている。さらと、Brintonは、
Actman の株を用いて、線毛素を ${ }^{20} I$ でラベルし、 そのトリプシン消化後クロマトグラフにより、A 遺伝子の変異が、線毛素のアミノ酸の変化である ことを示した。この結果は、A 遺伝子が線毛素の 構造遺伝子であるととを強く示唆する。また $\mathrm{D}$ 遺 伝子についてす、ての変異株でR17フォージの感 受性が低く、高濃度の $\mathrm{Ca}^{++}$要求するととを示し た。従って、D遺伝子も線毛の構造または機能に 関与する遺伝子と考えられている。

\section{結 果}

各種の変異 $F^{\prime}$ 因子をもつ株のメノマイシンに対 する生残線を図に示した。

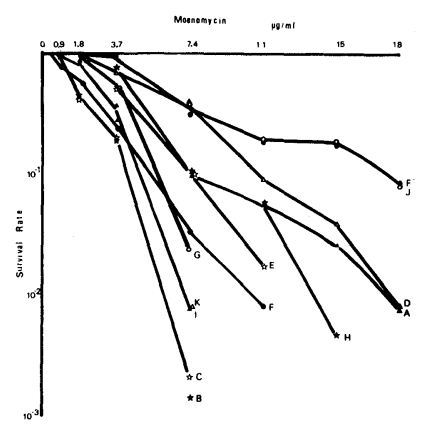

\section{考 察}

Willet tsらの伝達遺伝子の機能からわれわれの 成績を解釈すると、J遺伝子が欠損すると伝達遺 伝子の産物は全て作られなく、従ってメノマイシ ン感受性は現われないととは理解される。線毛素 の構造遺伝子Aの欠損および線毛機能に関与する $\mathrm{D}$ 遺伝子の欠損でメノマイシン感受性化が低らこ とは、線毛素の構造がメノマイシン感受性を決定 しているてとを示唆している。またB.C.I.K. 遺伝子の産物は仼とんどメノマイシン感受性化に 関与しないことが示された。以上の結果は、従来 より考えられていたメノマイシン感受性が、線毛 の構造蛋白によるメノマイシンの細胞内人の取り てみによるとする作業仮説を強く支持する。 


\section{○檀原宏文・吉川昌之介 ( 東大・医科研 )}

\section{目的:}

Rプラスミッドによる多剤耐性菌の増加は実地 化学療法上の大をな障害となり, 抗耐性菌剤の開 発が望をれている。既存の抗生物質の化学修飾に よる耐性菌対策の例としては deoxyk an amyc inがあ り, 臨床的にも著しい効果が認められている。他 方, R プラスミッド保有菌に対して撰択的に殺菌 効果をもつ楽剤の検索も続けられ, At abrine, Macarbanyc in, Moenomyc in, S.D.S., Acridine dyes が報告されている。われわれは Kasugamycin(Ksg) がRをたは F プラスミッド保有菌に対して撰択的 殺菌効果をもつてとを既に報告した（第31 回本学 会関東支部総会）。そてで今回はKsgの R プラス ミッド保有菌に対する増殖阻害効果を詳しく検討 し, Ksgの抗 $\mathrm{R}$ プラスミッド剤としての実地医学 面での有用性を論じたい。

\section{方法:}

菌株は大腸菌 $\mathrm{K}-12$ 由来 $\mathrm{CS} \mathrm{H} 2, \mathrm{CR} 34, \mathrm{~J} \mathrm{E}$ 346 および W 4573 を使用した。 Rプラスミッド は R 100， R 100-1， F プラスミッドは F 8 gal を使用した。Ks gは微化研, 梅沢先生より分与を 受けた。Rおよび F プラスミッドの“除去”はそれ ぞれ penicillin screening 法および f2 Phage selection 法によった。感受性試験は各濃度の Ksg を含む 5 mlの PAB $\sqrt{ }$ C, O D $600 \mathrm{~nm}: 0.7$ の菌液 $0.05 \mathrm{ml}$ を加え $37^{\circ}$ 静置培養し経時的 $\mathrm{COD} 600 \mathrm{~nm}$ を測定した。耐性分布試験は Ksg $\mathrm{O} \mu \mathrm{g} / \mathrm{m} \ell$ から $320 \mu \mathrm{g} / \mathrm{ml}$ までの倍数濃度を含む EMB 寒天培地 に上記菌液を適宜希釈して塗抹した。また感受性 試験と併行して, 生菌数とレプリカ法による $\mathrm{R}$ 菌 の出現頻度を求めた。

結果および考察：

I. $\mathrm{R}^{+}$菌, $\mathrm{F}^{+}$菌の Ksg 高感受性 (Epistat ic Sensitivity )

CSH 2, CSH 2（l $100 ）$ およびJE 346, JE 346 ( F 8 gal )を Ksg 存在下で培盖すると
$160 \mu \mathrm{g} / \mathrm{m} \ell$ 以上では $\mathrm{R}^{+}$菌の増殖は $\mathrm{R}^{-}$菌に比し著し く抑えられ， $640 \mu \mathrm{g} / \mathrm{m \ell} て ゙ は \mathrm{R}^{+}$菌は 40時間培養して も OD 值は増加しなかった。 $\mathrm{F}^{+}$菌も $\mathrm{F}^{-}$菌に比し Ks g 存在下で增殖が著しく阻害された。次に R 100 およびF 8 galをそれぞれJE 346およびW 4573 に 再伝達して $\mathrm{R}^{+}$菌および $\mathrm{F}^{+}$菌をえた。乙れら $\mathrm{R}^{+}$菌, $\mathrm{F}^{+}$菌は共に Ksg 感受性であった。更に CS H 2

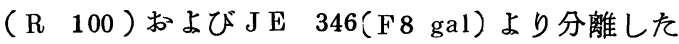
$\mathrm{R}^{-}$菌, $\mathrm{F}^{-}$菌は $\mathrm{Ksg}$ 感受性でなかった。

以上の結果は $\mathrm{R}^{+}$菌, $\mathrm{F}^{+}$菌の $\mathrm{Ksg}$ 感受性化は $\mathrm{R}$, Fプラスミッドにより賦与されたととを示するの である。

II. $\mathrm{R}^{+}$菌の Ksg resistance determinant

$\mathrm{R}^{+}$菌をKsg $160 \mu \mathrm{g} / \mathrm{m} \ell$ 存在下で長時間培養し その対数期増殖より $\mathrm{Ksg}$ 耐性菌を分離した。乙の $\mathrm{Ksg}$ 耐性 $\mathrm{R}^{+}$菌はもとの $\mathrm{R}^{+}$原株より $\mathrm{Ksg}$ 存在下で 増殖が早ん。また $\mathrm{Ksg}$ 耐性 $\mathrm{R}^{+}$菌のもつ $\mathrm{R}$ プラスミ ッドの伝達, “除去” 実験により乙の Ksg 耐性変 異菌の Ksg 耐性は染色体の変異によるものである ことが明らかとなった。

III. $\mathrm{R}^{+}$菌の Ksg耐性変異菌出現頻度

$\mathrm{R}^{+}$菌の $\mathrm{Ksg}$ 存在下での Growth kinetics, $\mathrm{R}^{-} \mathrm{se}^{-}$ gregant の出現および耐性分布試験により次の事 が考えられる。すなわち $\mathrm{R}^{+}$菌は少くとも三つのタ イプ 1) $\mathrm{R}^{-}$菌に比しKsg 感受性を示すタイプ （ $\mathrm{R}^{+}$菌の大部分を占める） 2） $\mathrm{R}^{-}$菌程度にKsg 感受性を示す $\mathrm{R}^{-}$segregant および 3) $\mathrm{R}^{-}$菌に比 しKsg耐性を示すタイプにより成り立っている。

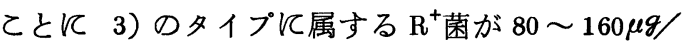
$m \ell \mathrm{Ksg}$ 含有寒天平板培地上で $\mathrm{R}^{-}$菌より高頻度で出 現することはこの種の薬㓮の実地医学上での一つ の問題点であろう。現在, R 100-1 以外の Rプラスミ ッド保有菌に対するKsgの増殖阻害効果の有無につ いて検討中である。また，R 100-1の欠失変異株を分 離中であり, ての変異株を使用するてとにより R 100$1 の$ Epistatic sensitivity gene(s)の解明が期侍される。 
私どもはカスガマイシンの作用機構を研究 した結果、カスガマイシンは細菌のリボゾー ムの $30 \mathrm{~S}$ サブュニットに作用し、30S initiation complex 形成を阻害するてとにより、 タンパク合成の開始機構に選択的に作用する ことを明かにした。大腸菌のカスガマイシン 耐性に関しては、16S rRNAの非メチル化に よる耐性 $\mathrm{ksg} \mathrm{A}$ （耐性の遺伝子座位 1 分付近）、 細胞膜の透過性の変化による耐性 $\mathrm{ksg}$ B （遺 伝子座位 25-39分の間) が報告されている。 私どもは最近、これらと異なる新しい型のカ スガマイシン耐性を見出し、 $\mathrm{ksg}$ C $と$ 命名し たので報告する。

大腸菌 K1 2 AB 312 (Hfr, lac, thr, leu, thi, $\underline{\operatorname{str} A}, \underline{\text { fus }) を=ト ロ ソ ク ゙ ア ニ シ ゙ ン ~(N ~}$ $T G)$ 処理するてとにより、カスガマイシン耐 性菌を得、タンパク合成系の再構成と、リボ ゾーム・タンパクの二次元ポリアクリルアミ ド電気泳動法によつてカスガマイシン耐性を 解析した。無細胞タンバク合成采において poly UGを mRNAとして valine のとりてみ をしらべると、カスガマイシン耐性は S 100 分画ではなく、リボゾームに存在するととを 認めた。70S initiation complex 形成につ レて、カスガマイシン耐性は initiation

factors ではなく、washed $70 \mathrm{~S}$ ribosomes に存在するととが判明した。 valineのとり こみを指標としたリボゾームの30S サブユニ ットの再構成実験では、カスガマイシン耐性

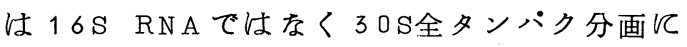
存在するてとが認められた。さらに、二次元 ポリアクリルアミド・ゲル電気泳動法によりカス ガマイシン感性株と耐性株の30Sリボゾーム・ タンバクを比較した所、カスガマイシン 耐性株 においてS 2 タンパクのspotが消失し、その付 近に新しいspotが認められた。
A B 312 (ksg C) 㤌カスガマイシン耐性になる と同時に、 $\overline{\mathrm{Lac}}^{-}$力ら $\mathrm{Lac}^{+}$に変異しているて とが認められた。このととは $\mathrm{ksg} \mathrm{C}$ 遺伝子座 位が年空座位の付近にある可能性を示唆する ものと考えられる。AB312（ $\mathrm{ksg} \mathrm{C)}$ は Hfr としての能力を失つており、ての株から P 1

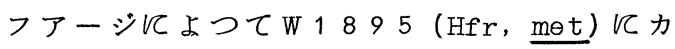
スガマイシン耐性を導入した菌株は耐性度は 低下しているが、てれについて、前記の方法 でしらべた所、S 2 タンパクが同様に変化して いるととを認めた。

前記のよ5 亿、 $\mathrm{ksg} \mathrm{C}$ 座位は $\mathrm{lac}$ 座位の付 近に存在する可能性が考えられるので、1 の近くにいろいろな markerをるつ $\mathrm{F}^{-}$菌 J $\mathrm{E}$ 346 を用い、これとW1895 ( 接合させ、遺伝子組換え実験を行い、 lac, pur E, ara, mt1 などについて選択した結果 、 $\mathrm{ksgC}$ U $\mathrm{pur} \mathrm{E}$ (1 2 分)の付近飞存在するて とが推定された。さらに、P1フアージによる 形質導入によつて、 pur-と. $\mathrm{ksg}$ 耐性とは 90 \% 以上 co-transduction を行 5 とが観察さ れた。この結果、 $\mathrm{ksg} \mathrm{C} は$ pur Eの付近（約 0.13 分の範囲) 飞存在するるのと考えられる。

カスガマイシンはリボゾームの30S サブュ ニットへのfMet-tRNA により、タンバク合成の開始機構を選択的に 阻害する。また、カスガマイシンはょ2フアージ RNA $\oslash$ cistron-specific initiation $\nwarrow$ differential な阻害を示す。てのてとと前 述の結果から、S 2 タンパクはfMetーtRNAF の30Sサブユニットへの結合、さらに cistronspecific initiation $\oslash$ regulation $\nwarrow$ 関係 する initiation-specific proteinの一つで あると考えられる。

大腸菌 K. 12 ではリボゾーム・タンバク（抗生物 質耐性）の遺伝子座位は str A (64 分付近) 飞 cluster をなして存在するが、S 2 (カスカ マイシン耐性)がこれに離れて、1 2 分付近に存在する ことは興味あることである。 


\section{Streptococcus.のChloramphenicol耐性機序に関する研究}

\section{○仁田原義之 落合宏 宮村定男（新潟大・医。細菌）}

\section{且的}

薬剤耐性のStreptococcus の検出率は従来少 いものであったが, 最近 Tetracycline (TC)

Macrolide, Chloramphenicol(CP)等飞耐 性の菌株が分離されるようになってきた。CP 耐性 の機序が，その不活化酵素に関係することを，私 共は, 1960 年以来, グラム陰性桿菌及びブドウ球 菌等について報告しているので，本菌の耐性機序 についても関心をもっていたが，今回臨床材料由 来の $\beta$ 溶血を示すStreptococcus 52 株より $\mathrm{cP}$ 耐性株を 1 株見出し，この菌株がCP不活化作用の あることを認めた。よって, この菌株を用いて耐 性と不活化作用の関係及び不活化作用の機序関 する研究を行った。

方 法

耐性菌のスク!ーニングは $\mathrm{CP} 10 \mathrm{mc} / \mathrm{m} \ell$ 含有血液 平板で行い, 最少発育阻止濃度はHeart Infusion（HI）Brothを用いた試験管希釈法で行っ た。判定は $37^{\circ} \mathrm{C} 18$ 時間培養後行った。CP不活化 作用はBacillus subtilis ATCC6633を検定菌とする かック法で検するBioassay法により残存力価を測定する ことで判定した。CP分解産物の性状は供試菌培養 液と一定時間反忘後, ブタノールで抽出し蒸発粉 末とした試料について赤外線分光分析を行うこと によって検討した。不活化作用の温度, 時間, 誘 導性, 温度抵抗性の検討は HI Broth 18 時間培養 液を用いた。又同培養液を遠心して得られた菌体 の0.1M phosphate buffer ( $\mathrm{pH} 7.8)$ 浮遊液 及び遠心上清滤液を用いて不活化作用の有無及び 活性化物質を検討した。不活化酵素の精製は超音 波処理による菌体破壊液より, 硫酸アンモニウム 塩析法及びSephadex G-100亿よるゲル瀘過法 によった。

\section{結 果}

臨床分離 52 株のうち 1 株がCPV耐性であった。 この菌は猩紅熱患者より分離され $\mathrm{A}$ 群, 12 型々属 した。その耐性パターンはpenicillin $0.9 \mathrm{u} / \mathrm{ml}$, $\mathrm{CP} 15.6 \mathrm{mcg} / \mathrm{ml}, \mathrm{TC} 15.6 \mathrm{mcg} / \mathrm{m} \ell$, Streptomycin $7.8 \mathrm{mcg} / m \ell$ Kanamycin $1.95 \mathrm{mc} / \mathrm{ml}$, Erythromycin $3.9 \mathrm{mc} g / m \ell$ であり,CP及びTCの 2 㓮耐性菌 であった。1 8 時間HI Broth培養液を用いた実 験では不活化作用はCPと接触後 1 時間後からみら れ, 3 時間後で最高に達し, 作用温度は $42^{\circ} \mathrm{C}$ が 最適であった。又CP $1 \mathrm{mc} / / m \ell$ 含有HI Broth培 養液で不活化作用は高まり, 誘導効果がみられた。 培養濾液には不活化作用は全く認められず，菌体 の 0.1M phosphate buffer (pH 7.8) 洗涤 浮遊液ではATP及び Coenzyme Aを添加するこ とにより不活化作用を呈した。CP分解産物の赤外 分光分析の結果, acetyl基の存在がみられ, こ の不活化作用は, acetyl-transferas'e亿よる 分解であることが推定された。

\section{考 察}

私共が分離したStreptococcusはTC及びCPの 2 剂而性株であったが，今回の実験によりでに関 しては, acetyl-transfera;s' 亿よる不活化機 構がその耐性の原因であると考えられた。

Streptococcusの耐性化は今後の化学療法上 大さな問題であるが，それにブドウ球菌の場合と 同様CP-acetyl-transferaseの存在が推定され たことはこの菌の耐性に R 因子が関与するものと して興味あることで, 不活化䤃素の性状を更に追 求すると共に, 遺伝学的解析を加えて, この菌の 耐性機構を検討したい。 
口腔 Fusobacterium の抗生物質による形態変化

北野繁雄, 玉置敬一，○山岡義明，宮川政子

片山有夫

目的

その培養術式の煩雑さ故に手のつけられて いない部分の多い嫌気性菌のうちで,グラム 陰性菌である口腔 Fusobacterium（以下 Fuso。) 飞対する経口合成 Cephalosporin C 系抗生物質のうち, Cephalexin (以下 CEX) の抗菌作用を, 各種濃度で発育曲線に及清す 影響を検討し，さらに発育曲線にあらわれた 異常を形態的な立場から電子顕微鏡レベルで 追求した。

方法

口腔由来の Fuso. 4 株（F9株，T4株， Y 7 株, Y 9 株) を供試し, VL変法培地 （pH 7.0）を用い， $\mathrm{CO}_{2}$ ガス噴射法による 嫌気培養法を応用して以下の実験を行つた。

1) 口腔 Fuso.4 株飞対する CEXのMIC 値を, VL変法液体培地を用いて, 液体稀釈 法で検討した。

2) Fuso。4 株のうち，とくに F9 株を供 試し, Bio scanner（生長培養自動記録装 置) をるらい，VL変法液体培地飞 C EXの各 種濃度を添加し，その発育曲線に及至す影響 を検討した。

3)さらに対数増殖期における CEXの影響 を, 経時的に形態変化を電顕レベルで検討し た。その試料作製法は次の通りである。

(a) 超薄切片試料として，4\%グルタール アルデヒドKellenberger 溶液を培地内に等 量加えて前固定を龵どてし，さらにっ％ $\mathrm{OSO}_{4}$-Kellenberger 溶液で後固定し, 通法 に従つて, Epon·812で包埋, 切片作製後, 酢酸ウラニルとクエン酸鉛液で 2 重染色し観 祭を行つた。

(b) 走査電顕試料としては，7.5\% 蔗糖含 有 $0.1 \mathrm{M}$ リン酸緩衝液をべースに，5\%グル
（城西歯大・微生物）

タールアルデヒドと1\% O $\mathrm{OSO}_{4}$ 溶液で二重固 定後, 液体炭酸に置換し, 臨界点法により試 料を乾燥後, カーボンと金で二重蒸着し観祭 を行つた。

結果及び考察

1) Fuso.のCEx 亿対する感受性，すなわ ち MICは, F9株 I.25 $\mathrm{\mu g} / \mathrm{mI}, \mathrm{T} 4$ 株

$3.13 \mu \mathrm{g} / \mathrm{ml}$, Y 7 株 $1.5 \mu \mathrm{g} / \mathrm{ml}$, Y9 株 I. $5 \mu \mathrm{g} / \mathrm{m}$ であり, 株によつて感受性に差 異があつた。

2) OEXが F9 株の発育曲線に及任す影響 はその添加量により異なり，それはMI0値 で，上昇率の低下ををたし，高濃度（10 $\mu \mathrm{g} / \mathrm{ml}, 20 \mu \mathrm{g} / \mathrm{ml})$ では, 添加後, 80〜 100 分で発育曲線の下降を示した。

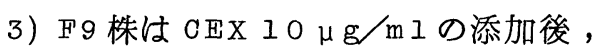
$80 \sim 100$ 分で分裂阻害を, 6 時間後には細 胞壁の形態異常を,さらにコ＼cjkstart時間後に細胞 破壊ををたした。

以上の結果加ら CEXは, 口腔 Fusobacterium飞対して抗菌性を示し，それはMIO值 以下では Bacteriostatic 作用し, 高濃度 $(10 \mu \mathrm{g} / \mathrm{ml}, 20 \mu \mathrm{g} / \mathrm{ml})$ においては Bactericidal 作用するととを, 発育曲線 と復元培養および電子顕微鏡像とで確認した。 


\section{目的}

近年緑膿菌による難治珄感染症に対する化学療法 剤として, Gentami cin, Dibekacin, Amikacin， Tobramycin などのアミノ配糖体抗生物質が使用 されているが，これらの抗性物質の作用機作につ いては, 生化学的に薬剤が 30 S リボゾームと結合 して蛋白合成を阻害する事が知られているが，一 方では菌体表層部と結合する事も報告されている。 今回私どもは，緑膿菌のアミノ配糖体抗生物質に感 受性株および耐性株について，その細胞表層に対 する変化を明らかにする目的で, 走査型電子顕微 鏡 (SEM) および透過型電子䫒微鏡 (TEM)を用い て研究を行った。

方法

使用菌株：薬剤感受性株として，Ps.aeruginosa No. 12 ，No. 21，Nc-5 を，耐性株として， Ps.aeruginosa GM-R No. 4 , No. 6 , PI - 67 を用いた。

使用薬剂: Gentam ic in (GM), D ibekac in (DKB) Amikac in (AM), Tobramyc in (TOB)

緑膿菌をTryptosoya brothで 18時間前培養し, こ の菌液をHeart Infusion broth に $5 \%$ 接種菌量と なる様に移植し，37ㄷ゙約 3 時間振とう培養を行 い，対数期途上に薬剤を作用させ薬剤添加後，1， 3,6 時間目にGlutaraldehyde で前固定後, 遠心集 菌しこれをRyter \& Kellenberger 法により $1 \%$ $\mathrm{OsO}_{4}$ で 18 時間本固定し，アルコール系列で脱水 を行った。TE M 試料作製の場合は, 脱水後 E poxy 樹脂に包埋し，LKB ultramicrotomeを用いて超薄 切片を作製し, 酢酸ウラニル, クェン酸鉛で二重 染色を行って，Akashi S-500を用いて観察した。 S E M 試料作製の場合には, 脱水後試料を酢酸イ ソアミルで置換, 臨界点乾燥法によって乾燥を行い, $\mathrm{Au}-\mathrm{Pd}$ を蒸着してJSM 35 を用いて観察した。

\section{結果}

T E M よる観察では, 薬剤感受性の緑膿菌 3 株
に, GM, DKB , AM, TOB を MIC 及び $10 \mathrm{MIC}$ 作用させ ると, 細胞質内の变化があまり見られない時点で,細胞 壁が各所で切断されたり，核物質が流出したり，ある いは細胞全体が丸くなる像が観察された。 3,6 時間 後になると細胞壁とともに細胞質膜も切断されて， 菌体内容物が流出して細胞質内が希薄になってい る像が観察された。

一方 G M 単剂耐性緑膿菌(Ps.aeruginosa PI-67)に $\mathrm{GM} 40 \mu \mathrm{g} / \mathrm{ml}$ を作用させても細胞壁の切断や細胞全 体が丸くなる現象は観察されないが, DKB $6.25 \mu \mathrm{g} / \mathrm{ml}$ TOB $1.56 \mu \mathrm{g} / \mathrm{ml}$ を作用させると，細胞壁が特異的に 切断され細胞内容物が流出している像が観察された。 さらに GM, DKB , TOBの 3 斉耐性緑膿菌 (Pa.aeruginosa GM - R No. 4 ) に GM, DKB をいずれも $40 \mu q . / \mathrm{ml}$ 作用させても細胞壁の切断は見られないが AM 12.5 从チ゚'in̂作用させると細胞壁の切断が見られた。ま た他の耐性緑膿菌を用いても同様交差耐性が観察され た。SEMによる観察でも薬剤感受性緑膿菌の場合は， 菌体内容物の流出や細胞全体の丸くなる像が多数観察 された。

\section{考察}

Davis らはStreptomycin の大腸菌に対する細胞質膜障 害について報告しており,その中で膜に障害を与える結果， 早期に K'の流出や Nucleotides の漏出が見られると述べ ている。今回,私共は緑膿菌にアミノ配糖体抗生物質を作用 させた場合,特異的に細胞表層が切断されることが判り， しかもその切断された表層より, Nucleotide 様のものが 漏出している像を認めることができた。また GM 耐性緑膿 菌に GMを作用させても細胞表層は切断されず, DKB な どの感受性薬剤では切断が見られた。従ってアミノ配糖 体抗生物質を作用させた時に,私共が今回観察した細胞 表層の障害は本物質の正しい抗菌像の様に思われる。 またアミノ配糖体抗生物質に対する緑膿菌の耐性化の 一因として細胞表層における透過性障害が考えられて いるが，果してこの様な細胞表層の障害と関連がある かどうかさらに検討中である。 
合成ぺニシリンにより伸長化した

緑膿菌の諸性状について

○尾花芳樹 黒田浩之 中沢昭三 京都薬大・微生物

目的

合成ペニシリンSulbenicillin(SB-PC)により 増殖を抑制されフィラメント状に伸長化した緑膿 菌に対し，食細胞がこれを容易に捕促・貪食する 知見を得たので，この本態を解明する目的で本実 験を行なった。

材料および方法

被検菌としてPs.aeruginosa NO. 12 およびNC－ 5 (強毒株) の 2 株を用い, 合成ペニシリンとし ては，SB-PC抢よび Carbenicil1 in ( CB-PC) を使用した。なお，伸長化菌は対数途上の菌に 終濃度が $25 \mu \mathrm{g} / \mathrm{ml}$ になるように SB-PCを加兄 2 時間振とう培養したものを用いた。

(1)形態観察：Nikon 位相差顕微鏡, J S M - 3 5 走 査型電子顕微鏡, Akashi S - 500 透過型電子顕微 鏡を用いて観察した。

(2)物理的条件に対する抵抗性：耐熱性試験は $60^{\circ} \mathrm{C}$, $100^{\circ} \mathrm{C}$ 行ない, 加熱処理菌を後培養にて判定した。 超音波に対する抵抗性は, 処理液を過塩素酸で除 蛋白し, 遊離核酸を $260 \mathrm{~nm}$ で測定した。又,石炭酸 に対する抵抗性は石炭酸係数測定法に準じて行なった。 (3)化学的条件に対する抵抗性：Lysozyme（エー ザイK.K.ノイチーム) に対する感受性は，菌体を M/15-PBSに懸濁させ，各濃度のLysozymeを 添加し，O.D. $550 \mathrm{~nm}$ の濁度変化で測定した。 Gentamicin (GM) の取り込みと殺菌能は， Bioassay 法と生菌数測定によって検討した。

(4)病原性：Ps . aeruginosa NO. $12, \mathrm{NC}-5$ の菌液 と $4 \%$ ムチンを等量混合し, ddYSマウス(子16士 $1 g)$ の腹腔内に接種し，生死を7日間観察した。 (5)菌体内毒素の毒性：フェノールー水抽出より得 られた内毒素の発熱性を, 日局八法に準じて行な った。カブトガ二血球溶解液を用いた limulus test た。マウスに対する毒性は, 内毒素を尾静脈に接 種し，7 日間生死および体重変化を観察した。
モルモット( $3300 g)$ 腹腔内マクロファージに対する毒 性は，Trypan-blue 染色による生存率で測定した。

成績

(1)形態観察：SB－PCにより菌体が著しく伸長化する が，それ以外目立った形態変化はない。

(2)物理的条件に対する抵抗性：熱に対して 伸長化菌 は正常菌に比べ弱い傾向にある。超音波に対しても 伸長化菌は正常菌に比べ抵抗性が低く, 遊離核酸量 が早く平衡值に達する。又, 石炭酸に対しでも伸長化 菌の方が抵抗性が低い。

(3)化学的条件に対する抵抗性：Lysozymeに対する感受 性は,正常菌では 濁度の低下は見られないが, 伸長化菌 では 作用後 1 時間頃から濁度の低下が始まる。GMの 取り込みでは, SB-PC, CB - PCで伸長化した菌は, 正常 菌に比べ 1.5 1.8倍の GMを菌体へ取り込み, 生菌数測 定でも, 伸長化菌は GMの殺菌作用が増強されている。 (4)病原性：マウスに対し, Ps.aeruginosa NO. 12 の伸 長化菌は正常菌に比べて 著しく毒性が低く, NC - 5 では 両細胞にほとんど差はなかった。

(5)菌体内毒素の毒性: 発熱性は, 正常菌の発熱活性は伸 長化菌の 2.3 5.5 倍高く, limulus testに於いても正常 菌のゲル化活性は 5〜10 倍高い値を示している。マクロファ ージに対して 伸長化菌内毒素は 毒性がないのに対して, 正常菌内毒素は 強い毒性を持つ。又, マウスに対して 致 死量は両者とも $1.2 \mathrm{mg} / \mathrm{mouse}$ であり, $0.8 \mathrm{mg} /$ mouse を接 種後 体重の変化をみると, 3 日後までは ほぼ同じくらいの 体重減少があるが,その後の回復は伸長化菌の方が良好で あった。

考察

以上の成績より考察すると,合成ペニシリンにより増殖を抑制 され伸長化した緑膿菌は, 正常菌に比べ多くの性状に違いが 認められ, 病原性や毒性も低下していた。このことは, 化学 療法に於いてこれらの抗生剂が単に直接的な殺菌作用を示 すだけでなく,増殖を抑制し二次的な効果を有していること を示している。この様な性状の変化は, 宿主感染防御に とって 甚だ好都合な現象と考えられ，さらに免疫学 的な検討を加えている。 


\section{目的}

Fosfomycin(FOM)はPenicillin(PC) 系や Cephalosporin (CEP)系抗生物質之同様に細菌の細胞壁合成 阻害抗生物質である。しかしながらその化学構造はこ れらと異なり，天然物ではまれな $\mathrm{C}-\mathrm{P}$ 結合をもった抗 生物質である。今回この FOMに関する細菌学的評価 を行ったので報告する。

方法

(1)抗菌スペクトラムは日本化学療法学会標準法を用い て実施した。なお接種菌は普通ブイョンに 18〜24 時 間培養した菌液を隇菌生理食塩水で 1,000 培希釈した ものを用いた。

(2)抗菌作用型式については Bi ophotome ter(JASCO Bi o L Log II)を用いてその増殖曲線を観察した。なお Stap.aureus 209-PJCの場合には同時に生菌数測定を併せて実施した。 (3)大腸菌 E. coli NIHJC-2に対する抗菌像については位 相差顕微鏡 ( Nicon)を用いて観察した。なお透過型， 走査型電顕による観察も行った。

(4)耐性菌の出現頻度については 18〜24時間前培養菌と 10 倍 濃度の薬剤を各 $1 \mathrm{ml}$ づつ加え, 更に普通寒天培地を $8 \mathrm{ml}$ 加光; 48時間後に出現してくるコロニーを数えた。E.coli NIH JC -2 の耐性菌の性状についてはガス産生能, 乳糖分解能はT.S. I. 培地(栄研)を用い増殖速度は比濁によって観察し, 毒力は ddYSマウス体重 $15 \pm 19$ を1群5匹とし,尾静脈に接種して行った。 (5)他剂との併用効果についてはBOX法を用いて検討 した。なお Lysozyme との併用については生菌数測定も 併せて行った。

(6) F O M投与による大腸菌感染マウスの血中, 葴器内 菌数の消長と血中, 腎藏内薬剤濃度の測定は dd Y S ? ウス”体重 $16 \pm 1 g$ を用い, 経時的に臓器を摘出して ホモジネートし常法の混釈平板法により生菌数を測定し 一方薬剤濃度測定の場合は B.subtilis PCI 219 を試 験菌としてカップ法でBioassay した。

成績

(1)抗菌スペクトラム

F O M はグラム陽性球菌, 桿菌, グラム陰性桿菌に有
○斉藤正人 中沢昭三 京都薬大・微生物

効である。

(2)作用型式

Stap.aureus 209-PJCについてはM I C 濃度以上では Dose responseが見られず 8 MICにおいてもMIC と その菌数は同じであった。

(3) E.coli NIHJC-2に対する抗菌像

Penicillin系や Cephalosporin系抗生物質と異なり フィラメント状の伸張化は見られずそのまま溶菌する 像が観察された。

(4)耐性菌の出現頻度と諸性状

E.coliについては約 $10^{-6}$ というかなりの高頻度で酎性菌 の出現が見られた。E.coli NIH JC-2 の耐性菌諸性状に ついては感受性菌と差異は認められなかった。

(5)他剂との併用効果

E.coli NIH JC-2については併用効果が認められなかっ たが Stap.aureus 209-P JCについてはPericillin G， Cephalexin,Ly sozyme との間に協力効果が認められた。

(6) F O Mの動物実験

$100 \%$ 生存させ得るF OMを投与して検討した。6時間後の 測定では F O Mを血中, 各藏器より検出できなかったが, 菌 数については $10^{5} \sim 10^{6} \mathrm{cells} / \mathrm{g}(\mathrm{ml})$ 検出された。

\section{考察}

Fosfomycin はグラム陽性球菌, 桿菌, グラム陰性桿菌 など広い抗菌スペクトラムを有する抗生物質であり， 生化学的に Cell Wall 合成の最初の段階を阻害すると言 われている。形態学的に抗菌像を観察するとPC系, CEP 系抗生剂とは異なりフィラメント状に伸張化せずにその まま溶菌し,この点でも同じ細胞壁合成阻害の PC系, CEP系 とは異った態度を示し生化学的知見を反映している如 くである。次に本物質の欠点としては耐性菌の出現頻度が 高いことである。そしてこの耐性菌の性状は感受性菌 のそれと大差が認められなかった。次にこの欠点を補 う意味で他剂との併用効果を試みるとブドウ球菌の場 合，PC, CEP系の抗生剂やリゾチームとの間に明瞭な 協力作用がみられたことは興味深い。 
務台噭。（ヤクルト研）

目的

消化管内における常在菌の “住み分け "の機構 の解明

\section{方法}

涌常ラットから分踓した紫内纽菌老色々な組み 合わせで整获ラットル投与し，その時の消化管各 部方菌業の構成を调らべ, 通常ラットの常在菌 丵の構成と比輍するととにより消化管内のそれぞ れの部位における湖々の荣の動熊をとらえた。 実絤虭物群

I。 GB 5. . E. $\underline{\operatorname{col} i} \mathrm{~N}-1$, S. $\theta$ pidermidis $N-1$, S. $f a \theta c a l i s$ var. Iiquefaciens $\bar{Y}-\overline{5}$, B. fragilis GAM-8 Fusiform bacteria $E G-1$ の 5 侏投与

II. G B 6 。 5 株斗 L a c t b a cillus $\mathrm{spp}$.

III. $G B 5+A n a e r o b e s$

IV. $\mathrm{GB} 6+\mathrm{An} a \theta \mathrm{r} \circ \mathrm{bes}$

V. Conventionalized

Vl. Conventional

\section{結果叔び考祭}

胃の菌丵——ー lactobacilliのい

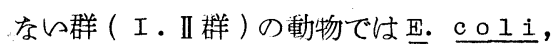
streptococciが最優势で, その藏枚は lactobacilliのbる䡃物比べ高かつた。 lactobacilliのいる䡃物では, 非腺胃部の 㑇質化細胞への乙の菌の特異的な付着がみられた。 しかし, Iactobacil】斺ない動物では S. $\theta$ pidermidis $N-1 の$ 再質化紬物, $の$ 付着が覞祭され, これはlactobacilliの投 与佀つて排除された。ての特のIｏctobacilli によるs t a phylococ cus の排除は非腺胃 部の壁だけに限られたものであつた。 小腸の菌叢-D- - 特飞 I。II 群の動物の小腸 上部における菌の。ver g r o w th がみられた。
てのような動物にさらに偏性嫌気性菌群を投与す ると（IIIIV群）, この部位の菌叢は正常に近く なつを。小腸の下部では些。里i，strepto一 c ○ c c i の菌数は工群で有意仁高い。II。II群で はエ群よりも低いがIV.V，VIよりも高い。すなわ

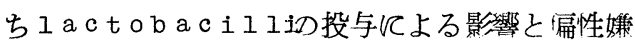
気性菌群の作用が観祭できる。

盲腸の菌丵ーDー一盲腸では上。coli, streptococciの菌数はI。正群で有意に 高く，IIIIV群では I。II群と V。V群の中間の 值をとる。】 a c tob a ci工的菌数は II 群では, V、V群よりも有意に高い。IV群においても高い 傾向くある。

腸内細菌叢の变化はし代しば病的状熊にともな つてみられ, あるいは菌叢の変化が病気の原因と なるとともある。常在菌叢と病原菌との拮抗作用 はよく知られているが，乙の㙨粠は基本的には常 在菌の"住み分け”を調整している機構と同じもの であると考えられている。そてで"住み分け"と いう点て注目して，消化管のそれぞれの部位にお ける個々の菌の動熊をとらえてみた。“住み分け” の機粠の解明にはさらに異なつた視点からの研 究が必要であるが，垷在までに得られた結果は 次のように要約される。

1.それぞれの部位における最優勢の菌がその 部位における䔉㨍棈成の調整に働いているこ $\varepsilon_{0}$

2.大腸に住む嫌気性菌は消化管運動を亢准さ せ，間接的に小腸菌築の構成の調整にも働い ているとと。

3. 常在菌の消化管上皮細胞次対する付着能力 は菌叢の構成を規定する一因であるとと。 
○辯野義己 難波希三子 鈴木邦夫 光岡知足 (理化研)

\section{目 的}

近年，人の大便内梳，Bacteroidaceae， Eubacterium, Bif idobacterium, Peptostreptococcus など偏性嫌気性菌が最優 勢菌叢を構成し, その数は好気性菌の $10^{3} \sim 10^{4}$ 倍にも達することが明らかにされるとともに，こ れらの菌の宿主に科る役割が，発ガン，老化， 栄盖，嫌気性菌感染症などとの関連が重要視され ている。

一方，乙れら偏性嫌気性囷の分類・同定にはな お多くの問題が残され，したがって大便内細菌叢 の菌種 (Species) レベルにおける構成について は，殆んど研究されていない。

演者らは, 腸内優勢嫌気性菌叢の菌種レベルに おける菌種の同定及びその出現菌数について検索 したので報告する。

\section{材料と方法}

材料は，すべて健康成人の大便を用いた。大便

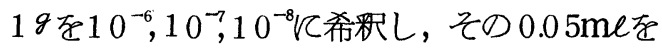
EG agar,BL agar, M10agar 飞塗抹し, 嫌気 性スチールウールジャー法, Plate-in-bottle 法を用いて 48 時間から 72 時間培養を行った。

培養後, 各対応する培地飞釣菌し, 純粋分離し た後，好気性菌を除外し，集落性状は, BL agar， EG agar を用々，菌形態は，BL agar,EG agar を 48 時間嫌気性培養後検査した。

増菌培地及び性状検査の基礎培地は，EG-

Fildes broth 飞用々，増菌培地にはさらにGlucose 1\%, Soluble Starch 0.5\%を加えて用い た。性状検査は, ガス産生能, Bi le 凡よる発育 促進性, $\mathrm{H}_{2} \mathrm{~S}$ 産生能, 運動性, ビタミンK要求性, 抗生物質抵抗性, 糖分解能 ( 29 種類) を検査し, 10 日間培養を行った。

アルコール，揮発性脂肪酸及び不揮発性脂肪酸 の定性定量分析は，ガスクロマトグラフィーによ つて行った。
結果及び考察

健康成人 9 例の大便を検索したとてろ，出現頻 度，出現菌数ともにきわめて高い菌種は， Bacteroides (以下B.) fragilis ss. vulgatus, B. fragilis ss. thetaiotaomicron, Eubacterium(以下E.) aerofaciens,Bif idobacterium (以下Bif.) longum, Bif.adolescent is Type a, B.oral is (または B. ruminicola ) などであった。出現頻度，出現 菌数ともに高々菌種は，Bmult iacidus, Megasphaera elsdeni i, Bif. adolescent is Type c, B.fragilis ss.fragilis, B.fragilis ss.distasonis, B.fragilis otherなどで あった。出現頻度は低々が，出現菌数がきわめて 高々菌種は，Bif.bifidum, Bif 。adolescent is Type d, B.fragil is ss oovatus, E.contortum, Clostridium( 以下C1. ) ramosumなど であった。

出現頻度は低く，出現菌数がそれ程高くない菌 種は, E.lentum, Fusobacterium russi i, Veillonel la parvula, Peptostreptococcus asaccharolyt icus, E.cyl indroides, B. hypermegas, $\mathrm{Cl}$. perfringens, などであった。 以上の成績とMOORE \& HOLDEMAN （1974）の日系八ワイ人を対象にした検索成績 と比較すれば，演者らの成績では，F，prausnitzi i, E。 el igens, E. rectale, Peptococcus productus, が検出されにくく，逆に，Bif。 bifidum, B.fragilis ss. fragilis, B. hypermegas, Bif.longum がより多く出現し， さらにMOORE \& HOLDEMAN で殆んど検 出されていない B.oralis またはB.ruminicola), B.mult iacidus, Megasphaera elsdeni i゙高率に出現した。 
甲畑俊郎, 今村博務, 望月泉, 渡辺邦友, 三和敏夫, 二宮敬宇, 上 野一恵, 鈴木祥一郎 ( 岐皁大. 医 ·微生物)

天野和雄, 高井輝雄, 高橋善彌太 (岐阜大・医・第一内科)

目的

嫌気性菌群が人体各部において最優位構成 菌群である事は周知である。これらの菌群が 人体に対して何らかの役割を生理学的にも, 病理学的にももつていると思われる。その意 味で，演者らは本菌群が多く存在する腸管を 対象に選び, 現在まで健康成人霬便内嫌気性 菌泼，化学療法剂投与によるその細菌裻の変 動などについて検討を加えてきた．今回，あ る病態下における本菌群の検索の為, 肝硬変 患者の糞便内嫌気性菌を対象とした。その理 由には, 肝性昏睡予防に Neomycin が用いら れている事である。本剤使用の理論的根拠に はアンモニア産生の腸管内細菌群の除去, あ るいは発育抑制が一つに挙げられている。し かしながら，本剤に対し腸管に多く存在する 嫌気性菌は感受性をもたない。不本菌群には アンモニアを産生する菌が多い。この事から。 肝硬変患者の腸管内嫌気性菌银の検索は細菌 学的にも臨床的にも大きな意義をもつと思わ れ，演者らの目的はここにある。

方法

岐皁大附属病院第 1 内科比入院加療中の肝 硬変患者 9 名, 激症肝炎 1 名, 䏣の5癌 1 名, 胃潰痬1名の計12名を対象とした。

自然排泄便を試料とし, 便採取直後, $0_{2}$ free $\mathrm{CO}_{2}$ 工 $00 \%$ の容器に収め, 科量する. 希釈液を $0_{2}$ free C $0_{2}$ ガス噴射下でその】0 倍量加え, 隇菌ビーズ玉を入れ，よく混和す る。同液より10倍段階希釈法による段階希 粎をくりかえし，」 $0^{-9}$ まで希釈する。予 じめ作製した各種の培地にそれぞれ目的とし た段階希釈の $0.1 \mathrm{~m}$ 〕を塗抹した。

使用培地には, GAM 寒天培地, $5 \%$ 血液 加 PEA 培地, Bacteroides 培地, 変法 FM培 地，SL培地， CW 寒天培地を用いた.
48 ７2 時間嫌気培養後, 菌数の質定, 釣 菌した。継代用培地には GAM 半流動培地を 用いた。

嫌気性菌の同定は主としてVPImanuaIに 準じた。な招好気性菌は菌数の質定にとどめ た。

結果および考察

Bacteroides は全例に分離され，その菌数 は $7 \times 10^{3} \sim \eta \times 1010$ 個であつた。

経時的にその変動を調べた中で Neomycin 投与例では好気性菌総数は1010 個オーダを 維持し, Bacteroidesは1010 $\rightarrow 109 \rightarrow 1010$ であり, Fusobacterium $10^{10} \rightarrow 10^{8} \rightarrow 10^{9}$

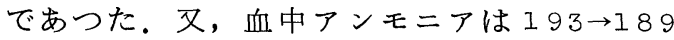
$\rightarrow 120$ であつた。

Clindamycin は in vitroで嫌気性菌に強 い抗菌力を示めすと言われているが，本剤投 与例では, 好気性菌総数は1010オーダを維持 し, Bacteroides など秝気性菌は106 個以

下に減少した。血中アンモニアは313 157 と減少した。

lactulose 投与例では総じて菌数の変動は 少なかつた。

Bacteroides, Fusobacteriumなど菌種レ ベルでは, 現在のところ1例について検索し たにすぎないが, B. fragilis ss, distasonis B. fragilis ss. fragilis, B. fragilis ss. vulgatasが109個オーダー, 又, F。 russiiが10 $0^{10}$ 個，F.variumが109 個に 分離された。

肝硬変患者 9 名の検索では, 加療前におい て嫌気性菌総数 $5 \times 10^{9} \sim 6 \times 10^{10}$ 個, 好気 性菌数 $8 \times 10^{8} \sim 12 \times 10^{10}$ 個がそれぞれ分離 された。健康人に比し, 好気性菌総数が多い 印象をもつた。 


\title{
$E-1-4$
}

\author{
ヒト腸内細菌叢に対するジハイド䓃文チル \\ フラトリジン（パンフラン $\mathrm{S}$ ) の影響
}

中谷林太郎、寺脇良郎 (東京医歯大・医・微生物)

犬上洋子 (公衛院)

目的

ニトロフラン系薬剤のらちジハイド砉岁チル フラトリシン（パンフラン S , P F S ）は赤痢菌 やサルモネラなどグラム陰性桿菌に強い抗菌力を 示す。 P F S 耐性菌壮少なく、をた P F S 耐性を 組込んだ $\mathrm{R}$ 因子はをわめてまれである。われわれ はP F S が培養細胞内の赤痢菌や病原大腸菌に対 し強い増殖抑制作用があり、細胞自体に対する毒 作用が微弱であることを報告した(第 46 回総会)。 今回は P F S を経口投与した際に、成人の腸内 フローラが如何なる変動を示すかについて検討した。 方法

泌尿器疾患の術前または術後に化学療法剤投 与の必要性を生じた成人 20 例 (男 17 例、女 3 例) の新鮮排出便中の各種細菌を定量培養し、14菌群 飞分類した。検体は同一例より P F S 投与前日と 投与終了翌日に 2 回採取した。P F S は 1 回 250 mg寺なは $500 \mathrm{mg} 1$ 日 4 回、3 日連続投与した。 11 例は P F S 単剂投与 ( A 群) 、6 例は $\mathrm{ABPC}$ と 併用 ( B 群)、 3 例で T C と併用 ( C 群) 群であ った。P F S 投与前後の排便回数、副作用の有無 を観察した。菌の培養は前法と同じく、光岡の方 法により13種の非選択・選択培地を用い、嫌気的

・好気的に行なった。

結果と考察

1. 全例に和ける P F S 投与前後の比較

(1) 菌数：P E S 投与後、次の菌群の菌数は著明 にまたはかなり減少した。総菌数、Bacteroidaceae, Catenabacteria Bifidobacteria, Clostridia。次の菌 群の菌数にはほとんど変動が認められなかった。 Peptostreptococci, Lactobacil1i, Streptococci,Enterobacteriaceae, Vei 1 lone 11 ae, Staphylococci, Yea$\mathrm{s}$ ts, Corynebacteria。

(2) 菌検出率：P F S 投与後、次の菌群の検出例 数は著明に減少した。Catenabacteria,Lactobaci$11 \mathrm{i}, \mathrm{Clostridia,Staphylococci。}$ 逆に Corynebacte- riaの検出率は増加した。その他の菌群では著明 な減少は認められなかった。

2. .A 群における P F S 投与前後の比較

(1) 菌数：P F S 投与後、次の菌群の菌数は著明 に減少した。Catenabacteria,Bifidobacteria,Peptostreptocicci,Clostridia,Staphylococci。次の菌 群の菌数もかなり減少した。総菌数、Bacteroidaceae,Veillonellae。以上の の減少は A 群に特徽的であった。

（2）菌検出率：P F S 投与後、次の菌群の検出率 は著明に減少した。Catenabacteria,Lactobacil1i, Clostridia,Staphylococci。次の菌群では検出率が かなり減少した。Bacteroidaceae,Peptostreptococ ci, Veillonellae。逆に Corynebacteria の検出率は 著明に増加した。

\section{B , C 群に打村万変動}

（1）菌数：A 群に比べて、緿菌数の減少は著明で あった。その他 Streptococci,Enterobacteriaceae の減少が特徴的であった。またCatenabacteriaで はあまり著明でなかった。

（2）菌検出率：A 群と大差なかった。

4. 排便回数の㙕加と副作用

P F S 投与開始後から中止 2 日後までの排便回 数は約 2 倍に増加したが、とくに認むべを副作用 はなく、全20例中に胃部不快感を訴えたもの2 例、 軟便 3 例、下痢 1 例であった。

5. 化学療法剤投与と腸内フローラ変動の 意義化学療法剂投与によりフローラが変動す るととは予期されるととであるが、嫌気性菌を含 めた変動を広乾に調べた報告は少ない。われわれ はスモン患者のフローラが異常を呈するととを発見 し、キノホルム服用と関連を有するととを裏付け た。各種化学療法剤のフローラ変動の特異性を調 ベるととは、菌交代症や副作用の発現に関連して 重要であると思われる。

(共同研究者) 山崎恵子、西村幸司、河村 毅 
サルモネラ感染と宿主反応一特に醳素組織化学的立場から

小沢 敦、大西信彦、沢村貞昭 渡辺慶一東海大。医。病理
東海大. 医。微生物

後藤甚作、国立東京第二病
且的 常在細菌叢と宿主との複雑なかかわり合を 多角的視点から解析してゆくととが、感染現象を 正確に把握する上に重要な問題であるので、サル モネラ感染とその宿主反応性を醭素組織化学的立 場を中心として解析するととにょりそのいとぐち の抽出を企図する。

方法（工）嫌気的条件下に和壮る連続流動培養装 置を用い Liver infusion brothを用いて Bacteroides fragilis または E. coli が S. typhimurium にたんして如何なる拮抗作用 を示すかを検討すると同時に、経時的に還元電位

（Eh）とpHの測定を併用しておてなつた。

（2） I CR 采無菌マウスを用いて経口感染実験が 企てられた。S。typhimurium の単感染におん て、腸管内堷殖パターン、菌侵入像および醅素組 織化学的反応性を経時的に追跡した。をた無菌、 ウススE. coliあるいはBacteroides fragilis をそれぞれ経口的に単感染し工週後に S. typhimurium を重感染した場合质、S. typhimurium の感染像が如何なる修飾をうけるかを細菌学的、 組織学的、酵素組織化学的立場より動態的に追跡 した。組織学的検索にはへマトキシリンエオジン、 パスおよびアルシャンブル一染色を併用し、酵素 組織化学的検索としてライソゾーム酵素 $(\beta-$ glucuronidasa $\beta$-N-acetylglucosaminidase) およびアルカリフオスフアターゼの組織 局在の動熊を追求した。

結果 嫌気的条件下に和㚈連続流動培養装置を 用々た実験て和々て、E。coliはS. typhimurium にたいして部分的阻止効果を示したが、Bacteroides fragilis Kよるs. typhimuriumk たいする阻止効果は原とんどみとめられなかつた。 またE.coliによるS.typhimuriumにたいする 阻止効果壮、Bacteroides fragilis の共存 により減弱される傾向がみられた。無菌、ウスを 用いた実験淤いて、Bacteroides fragilis
が先住定着しS. typhimuriumが重感染した場合、 Bacteroides fragi工i か腸管加急速に排除 される傾向がみられた。無菌マウスに s. typhimurium が単感染された場合にお々ては、小腸粘膜 に欮ける著明な浮腫の形成，goblet細胞の減少が みとめられ、乙のような傾向は Bacteroides fragilisが先住定着されたのちs. typhimurium が重感染された場合に和てるみとめられだ。か し、E. c01iが先住定着され S. typhimuriumが重 感染された場合に和々ては、浮腫の形成、goblet 細胞の減少という所見は厓とんどみとめられなかつ た。一方酵素組織化学的追跡におらて、無菌マウス においては小腸粘膜上皮表層およびゴルジ体域にお いて著明なアルカリフォスフアターゼ活性がみとめ られたが、腸粘膜および訮においては原とんど活 性がみとめられなかつた。しかん無菌マウスに

S. typhimuriumを単感染した場合に科ては、小 腸粘膜上皮表層にお壮るアルカリフォスフアターゼ 活性の著明な減少がみられ、それと逆比例的飞大腸 粘膜固有層域にお壮るマクロフアージ型反応に呼応 してアルカリフォスフアターゼ活性の増強がみられ た。そしてはた肝においても肺細胞とクッペル星細 胞との間のDisse's spaceに叔けアルカリフオ スフアターゼ活性の増強がみとめられた。また Bacteroides fragilis の先住定着後 S. typhimurium を重感染した場合におんては、アルカリ フォスフアターゼ活性の増減の程度はやや弱いが S. typhimurium単感染の場合とほぼ同じ傾向がみ られた。しかしE. coli之S. typhimuriumとの共 存の烫合には、小腸粘膜上皮表層に欮壮るアルカリ フオスフアターゼ活性の減少著明でなく、を肝

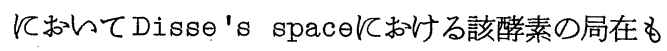
著明でなかつた。

考察 宿主反応性を酵素組織化学的立場から動態的 に追跡した結果を基盤として、常在菌叢と宿主との 間の複雑な相関性の中で感染現象を解析し考察する。 


\section{E-I-6}

\section{Yersinia enterocolitica 3 株の血清学的交叉性について}

猪野 茂、佐久間文久、○宇寿山満（福島衛研）

要約

Yersinia enterocolitica O抗原 3、5、9 型 3 株の $100^{\circ} \mathrm{C} 、 1$ 時間加熱菌及びアセトン乾燥 菌体より温フェノールー水で抽出して得られた多 桾体について 3 者間の血清学的交叉性を検討した 結果、加熱菌では3者間で交叉反応することが認 められた。又、多糖体に於いては，抗原 $3 \rightleftarrows 0$ 抗 原 $5 \leftarrow$ O抗原9の交叉性を確認することが出来た。 目的

我々は、Yersinia enterocolitica group の血清学的相関関係の解明を目的として検索を進 めてきたが、今回は０抗原 $3 、 5$ 及び9型の3株 について加熱菌及び多糖体間の交叉反応性につい て検討を加え、2、3の知見を得たのでここに報 告する。

\section{材料と方法}

供試菌株：Yersinia enterocolitica O抗原 3、5、9型 3 株

加熱菌体：B H I Agar $237^{\circ} \mathrm{C} 、 48$ 時間培養 して得た菌体を100 C、1 時間加熱し、菌体は更 に生理食塩水で2回洗浄した。

多糖体：上記と同一方法で培養して得た菌体を 0. $5 \%$ ホルマリン加生食水に浮遊し、4 C そて 48 時間放置後、菌体を分離し、アセトンにて乾燥後、 温フェノールー水にて抽出を行ない、得られた水 層は流水透析、減圧濃縮後、アルコールにて沈澱 乾燥した。

・フェリチン抗体法：硫安分画法で得られた 一ー グロブリンとフェリチンを結合させ、菌体と反応 させたのち、陰性染色を施こし観察した。

凝集価の測定：血清希釈法で行なった。

寒天ゲル内沈降反応：オクタロニーの方法に準 じて行なった。

定量沈降反応: 抗血清 $100 \mu$ 、抗原（多糖体量

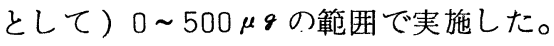

結果

100 C、1 時間加熱処理した菌体を用い、試験 管法で交叉反応性を検討した結果、3株間に明ら かな交叉性を示すことが確認された。又、フェリ チン抗体法を施こした菌体を観察した結果、菌体 表層にはェンベロープ様物質が認められ、フェり チン抗体の付着しているのが認められた。

多糖体については、試験管法、定量沈降実験、 寒天ゲル内反応を用いて検討した結果、O抗原了、 5 型間では弱いながら相互に交叉し合い、又、O 抗原 9 型は 0 抗原 5 型抗血清と交叉するが、O抗 原 5 型は 0 抗原 9 型抗血清とは全く交攴しないこ とが確認できた。

考察

菌体及び多糖体間の血清学的交叉性について㭘 討を加えた結果、前者では3者間でいずれも交叉 が認められるが、後者では 2 者間のみ交叉性が確 認された。又、フェリチン抗体法で抗原局在部位 を検索したところ、エンベロープ様物質の存在が 認められるところから、3者間の交叉反応に関与 している物質はＯ抗原多糖体及びェンベロープ様 物質に存在する可能性が推定される。なお、本菌 種間の抗原分類法によれば本実験に使用した 3 株 の○抗原は全く交叉しないとされているが、演者 らは、寒天ゲル内沈降反応飞於いて、弱い交叉性 が存在することを認めたので、エンベロープ様物 質と共に再検討の必要があるものと考えられる。 
Yersinia enterocolitica の病原性に関する研究：

Y.pseudotuberculosis との比較

○采克, 長田恭明, 小河秀正 ( 第一製楽研究所)

目的

先飞, Y.enterocolitica(Ye) の病原性に ついて in vitroでの上皮性細胞およびmacrophage と本菌との交渉, また, ウサギ感染実験像 からその解析を試みてきたが(第 46，47 回本学 会総会), 今回は, これらの観点から Ye と近縁 の菌として知られ，Ye 感染症と類似症状を惹起 するとされているY.pseudotuberculosis(Yp) と比較検討した。

\section{方法}

菌株は, 患者由来の Yp, TP- I 株 ( type V ), TPー2 株（III）および PSTー III 株（III）を用い，対照 として, 過去に報告した中で最も高い培養細胞感 染性を有し, ウサギに強い起病性を示す $\mathrm{Ye}, \mathrm{Te}$ 591 株を用いた。これらのPenassay agar(Difco)，2 $7 \mathrm{C}$ ，一夜培養菌苔を，それぞれ Eagle's $\mathrm{MEM}$ 培地および滅菌 PBSに平等浮遊し, 前者を 培養細胞感染系 $\left(10^{6} / m \ell\right)$ の, 後者をウサギ十二 指腸内感染系 $\left(10^{8}, \mathrm{~m} \ell\right)$ の接種衾夜とした。

培養細胞感染系は, host cell V HeLa S 3 細 胞を用い, $37 \mathrm{C}, 5 \% \quad \mathrm{CO}_{2}$ 下で 2 時關感染後。 緗胞外末感染菌を洗滌除去し, さらにKM $50 \mu \mathrm{g}$ $/ m \ell$ 含有培地で 5 時閒培養後, 紕胞感染率を求め た。

ウサギ十二指腸内感染系は, 白色短毛在来種の 幼若雄 (体重 $1.2 \sim 1.5 \mathrm{Kg}$ ) 在用い, 麻酔下で十二 指腸内に前記菌液の $10 \mathrm{ml}$ を直接接種した。

\section{成綪および考察}

1. 培金 HeLa 細胞との交渉：Yp壮各菌株と も強い細胞感染性を示し, その感染率は $35 \sim 45$ \%で, Ye,Te 591 絑 $(4.1 \%$ ）とほડ゙同等の 紐湖感染性を示した。紐胞内感染藏は原形質に形 成された小胞内にしばしば認められ，この点でも Ye の場合と類似していた。しかしypのらち外 毒素を産生すると言われている type III の PSTIII株和よびTP-2株感染時に, 細胞の変性, 剝離
がより著明であった。

2. ウサギ十二指腸内感染： いずれの Y p 接 種群に和いても, 感染後 1 週間以内に全例が死亡 したが, Y e 接種群は $2 / 3$ 例が生存した。

菌の藏器内分布： いずれの菌株接種群でも 肝, 脾末よび腸間膜りンパ節から多量の接種菌が 分陮されたが, その程度は, 総じて, Yp 接種群 がYe 接種群より大であり, とくに腸間膜りンパ 節からは, Yp 群では $10^{7} \sim 10^{8} / g$, Ye 群では $10^{4} \sim 10^{5} / g$ の接種菌が分離された。

病理学的検索：いずれの菌株接種群でも, 病変注小腸下部, とくに虫垂, 回盲部に著明で, 大縢はintactであった。肉眼的には, 漿膜面か ら白斑がみられ，とくに、Yp 群では粘膜面にし ばしば点状出血を認めた。組䋘学的には, 固有層 に菌塊の形成とともに微小潰瘍化した粘膜表在性 の病巣と同時に, 深部リンパ組織に肉芽腫性炎が みられたが, その程度はYp 群が大で, 加えて Yp, type III T P-2 株およびPST一 III株群では, 小腸下部全域にカタール性炎がみられた。とくに P ST一III 株にこの傾向が強い。晹以外では, いず れの菌株群においても, 総じて, 肝, 脾, 腸間膜 リンパ節に肉芽形成がみられたが, その程度は Yp 群が大であった。また, PST一III株の肝では, 肉芽腫と言うよりも，その壊死化病巣がみられた。 要約

Yp, Ye はともに培養細胞に汪ら゙同等の感染性 を示し、李た，ウサギに対し共通してリンパ組織 に肉芽腫性炎を惹起したが, その程度はYpの方 が大であった。また, Ypのうち, 外毒素を産生 するとされている type III の TP - 2 株, PST一II 株は培養細胞飞対する毒性が強く, リンパ組織肉 芽腫性炎に加え, 小腸下部のカタール性炎を,さ らにPST一吕株は, 肝に壞死病巣を惹起した。こ れらの点は, さらに菌株を増やして検討する必要 があると思う。 
$E-1-8$

表面感染の拡がり方に関する実験的研究

II. 粘漠スキャン法による接種菌の追跡

○松山東平（大阪市大・医・細菌）

要 約

1。クロマトスキャンナーを利用して、培養 粘膜での ${ }^{32} \mathrm{P}$ 標識接㮔菌の分布を、粘膜の 長軸にそって定量的に描出可能とした。

2 。 ${ }^{32} \mathrm{P}$ 標識の菌では、生きている湿潤な粘 膜のままでもスキャン出来るので、培養途 中の粘膜を経時的に調べられる。

3。 U V 照射して線毛運動を停止させた粘膜 を未処理の粘膜と比較スキャンすると、前 者は接㮔点に、后者は粘膜喉頭側端に $\mathrm{cpm}$ のピーク形成がみられ、mucociliary systemの健在を直接示す所見を得た。

目的

気道粘膜での表面感染成立拡大過程、宿主 による感染防禦機構の実態、接種菌と宿主組 織との特異的な関係等を調べるべく、培養粘 膜に㮔々の菌を点接㮔して実験を進めている が、今回、接種后の菌の動熊を定量的に調べ る手法として粘膜スキャン法を考案したので これを検討した。

方法

粘膜培養は前回 ( 73 年度) の発表通り家鬼 気管を使用し、点接㮔は、ca $0.05 \mu$ 工菌花 を微小白金耳で、粘膜の䐅頭側端と気管支側 端を結ぶ中点に行った。接㮔菌はStaphylococcus aureus.Staphylococcus epidermidis. Proteus vulgaris.Escherichia coli.Bordetella pertussis I 相、III 相菌、夫々を $\mathrm{KH}_{2} \mathrm{PO}_{4}$ を $1.0 \mathrm{mCi} / \mathrm{ml}$ 含む培地で成育させ、 后、洗净したもの（2１0 cpm/cfu）を使 用した。接㮔一定時間后、explantを Absorbent Pad(Millipore 社製)にのせ、Aloka Thin-Layer Chromatogram Scanner(Slit 巾 $1.5 \mathrm{~mm})$ に、かけた。経時的にスキャンする 場合は、Absorbent Pad 上の寒天に気管片を 半埋沈させたもので行った。線毛運動停止の explantは、接種直前に $10 \mathrm{~W}$ 殺菌灯で $9 \mathrm{~cm}$ の距離より 5 分間照射して得られるものを使 用した。

結 果

$100 \mathrm{efu}$ 前后の微量の菌接㮔でも、粘膜上 の分布動態を、気管長軸にそっての c pm の高 さの曲線として記録出来ることが明らかにな った。分解能は、アルミホイル上での 2 点識 別試験より $3 \sim 4 \mathrm{~mm}$ と推定される。

線毛運動が活発に認められる培養粘膜に点 接㮔した場合、直后に接種点にみられた cpmの ピークが、1 時間后には、堠頭側端へ移行し ている。この堠頭側端でのピーク形成は、い ずれの菌㮔でも認められた。線毛運動を停止 した粘漠の場合、喉頭側端での c pmは、気管 支側端と同じ低值を示し、ピークは接種点に とどまったままである。

考察

前回報告した細線白金コイルのスタンプに よる菌の分布記録法は、経時的に粘膜上の各 点での生菌の有無を調べることが出来たが、 各点での菌量に関しては、情報が得られなか った。粘膜スキャン法では、接種后の早い時 期に限られるとは云え、定量的に菌の分布を 追跡することが可能となり、より精密な実験 が出来ると思われる。運動性のある菌とない 菌、百日峐 I 相菌と $\mathbb{I I}$ 相菌の分布様式の違い は、目下、検討中である。又、生菌数の経時 的な変動分布に関して、マイクロホモジェナ イザー（ $0.2 \mathrm{ml})$ で区分粘膜の菌数計測を行 い上記の分布曲線と対比検討を進めている。 


\section{$E-I-9$}

ネズミコリネ菌のマウス経口感染

II . 菌の体内動態と潜在感染の顕性化

\section{○横井山繁行（東洋䁔造・研究所），藤原公策（東大・医科研）}

目的：さをに私達はネズミコリネ菌 Corynebacterium Kutscheri (以下 C 菌) 潜 在感染の発病病理に関連して、絶食とコーチン゙ ン投与の組合せにより、経口接種によつてマウ スを発病させることがでを、菌接種後/4日の コーチゾン投与によつてる一部のマウスが死亡 することをみた。今回は、rifampicin (以下 RFP ）耐性のマーカーを付与したマウス由来 $\mathrm{CK}$ エーRFPr 株を用んて、経口投与 C 菌の体内 動態と潜在感染およびコーチゾン誘発の機作に ついて若干検討した成績を報告する。

材料と方法： ICR-SLC, 4 W 令, 今マウス を24時間絶食させたのち，CK エーRFPr株の heart infusion agar (以下HI agar) 24 時間培養菌をゾンデを用いて胃内に投与した。 菌投与当日から90日後をで肺, 肝, 脾, 腎, 腸間膜リンパ節, 胃, 小腸各部, 盲腸, 大腸, 新鮮蕒便を RFP および amphotericin Bを含む HI agarr培養, 菌分離・計数を行ならととも r、病変, 血清凝集抗体の検索を行なつた。一 部のマウスにつんては、菌投与後種々の時期に コーチゾン $2.5 \mathrm{mg} / / \mathrm{O}$ g を皮下に/回注射し て発病の有無をしらべた。.

結果と考察： 絶食とコーチゾン投与を組合 せたICRマウスの CK ューRFPr株接種において わ、先に報告したddY マウスの実験と同様の経 過で肝の膿瘍形成を主徵とする致死的な感染が 成立した。コーチゾン非投与マウスでは菌投与 6 時間後の蕒便中に約 / O \% gのC菌がみと められ、投与菌の汪とんどが投与当日䔬便中に 排泄された。その後一部のマウスでは90日後

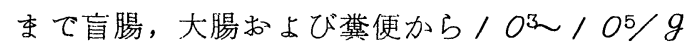
程度のC菌が検出されたが、胃, 小腸からの菌 分離陽性例数䏡上び菌数は盲腸に比べて著しく 少なかつた。したがつて投与菌の一部は盲腸を 中心とする消化管系に定着し、大腸, 顀便から
の分離菌は盲腸での増殖に由来するものと考え られた。このょうに、消化管, 霬便からの菌分 離陽性マウスでは、初期から腸間膜リンパ節に 菌が証明されたが、その他の藏器は菌陰性で、 病変, 抗体も検出されなかつた。

上述の保菌マウスは菌投与90日後でるコー チゾン投与に上り一部が発症死亡し、生残マウ スでも、肺, 肝, 腎の膿痬, 乾酪化病巣, 脾の 腫大などをしめし、菌分離, 抗体検索も流とん どが陽性であつた。てれに反して、䔬便からの 菌分離が陰性のマウスの多くは、コーチゾン投 与に上つても発症せず、病変, 菌分離, 抗体検 索なども陰性であつた。しかしながら、数例で は、蕒便中に菌を排出しなかつたにもかかわら ず、コーチゾン投与後に死亡し内臟病変がみら れた。とくに斗争に上ると思われる皮膚咬傷の みられたマウスでは、コーチン゙ン投与により局 所の潰痬が悪化し、皮虐傷部叔よび藏器病巣か ら○菌が分離された。病巣を有しながら、生残 した例では、菌分離, 抗体は陽性だつた。

以上のよらと経口投与 C 菌の一部は盲㔠を中 心とする消化管内に定着、増殖し、コーチゾン 投与に上り発病にいたるものと考えられた。ま た、粪便中に排泄された C菌が皮膚傷部に侵入 して感染が成立す方可能性も示唆された。乙の ことは、C菌の皮下接種により表在型の潜在感 染が成立したという Fauveら（／964）の成 績とも合致する。マウスおよびラットのコリネ 病が、一般に不顕性感染である(藤原／9.67 , 高垣ら/967, 内海ら/969) ととから みて、以上の上うな経口感染に上る潜在感染が 成立した事実は疫学的にもわて重要な知見と 考えられる。 


\section{E-I-1O}

K. pneumoniae による実験的マウス気道感染症について

\section{I. 感染条件の設定}

○西武, 土屋 皖司（武田薬品中央研）

K.pneumoniaeは古くから肺资の起因菌として知 られているが、本菌による実験的経気道感染症の 報告は多くない。をた抗菌剤のK. pneumoniae感染 症における薬効は主として腹腔感染系を用々て検 討されているが、この感染像は K.pneumoniae 感染 症における多くの臨床像とは著しく異なる。そこ で、より臨床像に近ん実験的感染症による楽効の 評価と、肺感染症成立の機構の解明の一助として、 K. pneumoniaeVよるマウス経気道感染を取りあげ た。今回㳉感染条件につんて検討した結果を報告 する。

方法 菌液: 保存株 K.pneumoniae DT-S15株を BHI broth 中で $37^{\circ} \mathrm{C}, 18 \sim 20 \mathrm{hr}$. 静置培養した後、 PBSまたはBHIbrothで約 $10^{9} \mathrm{CFU} / \mathrm{m} \ell の$ 菌液を調整 した。噴霧感染: 直径 $50 \mathrm{~cm}$, 高さ $45 \mathrm{~cm}$ つ合成樹 脂製 chamber 内にマウスを入れ、nebulizer ( USV PHARMACEUTICAL CORP, )で菌液を $1 \mathrm{~kg} / \mathrm{cm}^{2}$ の圧力 で 40分間噴霧した。定量培羑：血液は腋下より放 血採取した，肺および気管はそれぞれ $4 m \ell, 2 m \ell の$ $\mathrm{H}_{2} \mathrm{O}$ で乳剂とした。鼻腔は $\mathrm{H}_{2} \mathrm{O} 2 \mathrm{ml}$ で洗滌し、鼻 腔洗滌液とした。乙れらはTS A 平板表面あるい は混釈培養により生菌数を算定した。

結果 NebulizerV加ける压力の影響：同一菌液 を $0,6,1,0,1,4 \mathrm{Kg} / \mathrm{cm}^{2}$ 各王力で噴霧した場合、 噴霧終了直後のマウスの肺からは、深同数の生 菌が回収され、またマウスは同様の死亡経過を示 した。 Nebulizerのちがんの影響: 同一の菌液を 3 つのnebulizerを用いて噴霧した場合にも、マウス の肺からはほぼ同数の生菌が回収され、死亡経過 にも差を認めなかった。感染菌液の調整法の影 響：静置培養菌をPBSに浮遊した菌液で感染した 場合、感染終了直後飞マウスの肺から回収される 生菌は、BHIbrothに浮遊した菌液で感染した場合 より多かった。感染菌量の影響: $10^{9}, 10^{8}, 10^{7}, 10^{6}$, $10^{5} \mathrm{CFU} / m \ell$ 菌液和よび PBS 有用いて噴霧感染した マウスの肺から感染終了直後に回収される生菌数
は、それぞれ、平均 $10^{3.4}, 10^{2.4}, 10^{1.4}, 10^{0.4}, 0$ ， $0 \mathrm{CFU} / m \ell$ 肺乳剤で、感染後 2 週間までの死亡率は

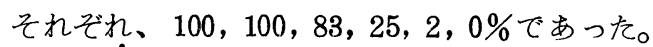
マウス系統による感受性の差異：体重 $20 \mathrm{~g}$ 前後, $4 \sim 5$ 週令のマウスにつを、死亡経過を指標とし て検討した結果、 $\mathrm{CF} \#^{1} / \mathrm{K}$ (武田) + , ICR-SLC $\delta$

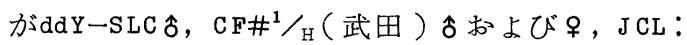
CF\#1より強い感受性を示した。週令および体

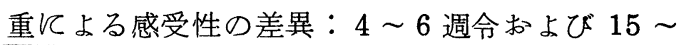
24gのマウスは、ほぼ同様な死亡経過をたどった。 感染菌のマウス体内における消長およびマウスの 死亡経過：ICR-SLC olC $10^{9} \mathrm{CFU} / \mathrm{ml}$ 菌液を $1 \mathrm{Kg} / \mathrm{cm}^{2}$ の圧力で感染した場合、肺では時間の経過と共に 著しい菌数の增加を示した（105倍）。気管では、 18hr. な゙僅かに増加( 100倍)したが鼻腔では 48 $\mathrm{hr}$, 後まで、依偪感染終了直後の生菌数を保持し た。血液中では、24hr、迄は検出でをなかったが、 $30 \sim 36 \mathrm{hr}$. 後にはすべてのマウスにおらて検出さ れ、この時期になると肝, 脾, 腎などにも検出さ れた。マウスは $24 \mathrm{hr}$. 頃迄は外見上著変を示さな らが、以後次第に元気を哀失し、42hr. 前後から 整死しはじめ、生残マウスは立毛、衰弱し、72 $96 \mathrm{hr}$.迄にすべて整死した。なお肺における病変は $24 \mathrm{hr}$.では小赤色斑が僅かに散在するが、30hr。以 後には明瞭になり、全肺葉に consolidation が出 現、72hr. 後の胸腔内には粘長性の高々滲出液が 認められた。

総括 マウスを直径 $50 \mathrm{~cm}$ 高さ $45 \mathrm{~cm}$ の chamber 入れ、 $\mathrm{K}$. pneumoniae $10^{9} \mathrm{CFU} / \mathrm{m} \ell$ 菌液存 $1 \mathrm{Kg} / \mathrm{cm}^{2}$ の 圧力で 40 分間噴霧することにより定常的に肺に感 染をおこし得た。この感染菌は主として肺で著し ら増殖を示したが、時間の経過と共に血液および 各種臓器でも検出された。 


\section{$E-|-|$ I}

\section{赤痢菌の細胞内侵入に関する研究}

○長田恭明, 采孟, 池内澄, 小河秀正

(第一製楽研究所)

目的 赤痢菌の細胞内侵入性 (起病性) 在解析 する目的で，それを規定する諸種因子の検討を進 めてをた。現在までに明らかにされたことは，菌 の細胞内侵入に際して, $\mathrm{Ca}^{\#}$ および $\mathrm{Mg}^{+}$が第一 義的に作用し，その作用は，キレート剤の EDTA によって相殺されるといらことである（第 $30 ，$ 31 回本学会関東支部総会で報告）。これらのこ とから，菌の細胞内侵入には何らかの酵素的物質 の関与が考えられる。今回は，この観点から，赤 痢菌の菌体外代謝物質に注目し，それの侵入性に 対する効果を検討した。

方法 使用菌株は, 強毒赤痢菌 S.flexneri 2 a，5503株で, 培地はLuria broth( LB) 秋よ びLuria $\operatorname{agar}(\mathrm{LA})$ を用いた。本菌株は, LB， LAV Ca\# あるいは $\mathrm{Mg}^{\#} 1 \mathrm{mM}$ 添加することによ り, その細胞内侵入性が有意に増強されるもので, これを $\mathrm{Mg}^{+}$添加 L B ( LB (十) ) および無添加 IB ( LB (一)) で $37^{\circ} \mathrm{C}, 18 \mathrm{hr}$ 振盪培養し, その遠沈 滅菌上清を透析, 濃縮して tris/ HCl 緩衝液 ( $\mathrm{pH}$ $7.2)$ でセファデックスG-150 分画を行った。 得られた粗画分（透析, 凍結乾燥標品) 壮, Eagle's MEM 培地飞溶解し，培養細胞感染系を応 用して菌の細胞内感染増強効果の有無を検討した。 すなわち，LA（一）培養菌を上記各画分を添加し たMEM培地に眯濁したもの（108/ml）を感染菌 液として, HeLaS 3 細胞に対する感染率を測定し, LA（＋）培養菌のそれと比較検討した。また, Dis c 電気泳動飞よって Mg*の存否による上記粗 画分の質的相違を検討した。

結果および考察 5503 株の L B (十) および LB （一）培養上清をセファデックス G-1 50 分画した ところ，いずれも同様な 2 つ粗タンパク画分が 得られ, 分画パターンからは LB $(+),(一)$ の間 には何らの差も認められなかった。しかし，LB $(+)$ 画分 $(\mathrm{P}-\mathrm{I}(+), \mathrm{P}-\mathrm{II}(+)), \mathrm{LB}(-)$ 画分 ( P-I (一), P-II (一), , 菌の細胞内感染に対す
る効果の比較では； L B (一) 画分が何ら効果を示 さなかったのと対し， LB (+) 画分ではPーII (+) に感染増強効果が認められ，その $10 \mathrm{mg} / \mathrm{m \ell}$ の添加 で LA $(\dot{+})$ 培養菌の細胞内感染率と同程度まで感 染増強がみられた。そこで，P-I $(+) ，(一)$ と P一I (十)，(一) をそれぞれDisc 電気泳動分画し たところ、PーI (十) 利よび (一) の分画パターン は明らかに異り，P-II(+)の方に $\mathrm{P}-\mathbb{I I}(-)$ には みられない特異画分の存在が認められ，雨者は質 的にも異ることが示唆された。

以上のことから, $\mathrm{Mg}^{+}$( あるいは $\mathrm{Ca}^{+}$) の赤痢 菌に対する細胞内感染増強効果は，これら金属陽 イオン依存性の高い特異代謝物質（タンパク）の 関与によるところが大であることが示唆された。 今後は,さらにこのものを単離精製し，これが菌 の細胞内侵入に関与していることを確認すると同 時に, 物性, 特飞 $\mathrm{Mg}^{\#}$ あるい: $\mathrm{Ca}^{+}$の存在意義が このものの代謝生成過程にあるのか, あるい壮 Staphy10^-cocous とみられるある種のプロテア 一ゼのように，その活性安定因子(自已消化防止 因子) (Arvidson. 1973 . Acta Path.Microbiol.Scand., $81: 552$ ) として働いているのか について検討を進め, 併わせて酵素学的性状を明 らかにする予定である。 
要的

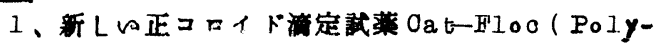

dialiglaimethyl ammoniun ohlortae) 、角 コロイド武摹PVSK ( Potassium polyvinyl

sulfate) を用的、TB(toluidine blue) を指 示督としてコロイド滴定を行なつた。

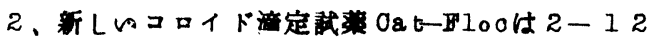

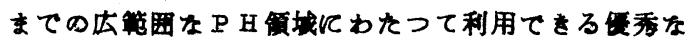
㜔定武蓧である。

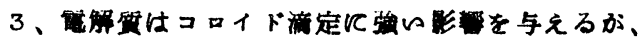

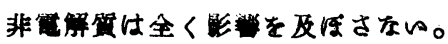

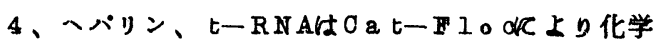
目的化㜔定された。

5、Myclococous lysodelotics のコロイド滳

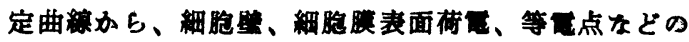
湌実を行なつた。

目的

コロイド消定法は寺山（I948）に上り創始された

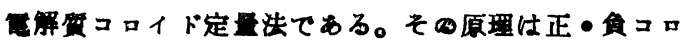

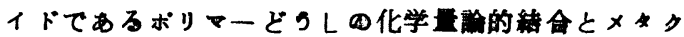
ロマシー現象を利用していた。しかし当時用いにれた

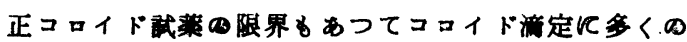
批判加集中したが千手の努力氏上つてその有用性が砣

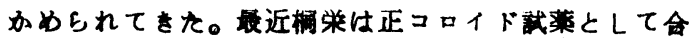
成高分子コロイドのat哣10cを見田出した。演者等は

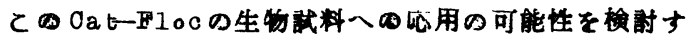
るためへバリン、t一RNA をコロイド滴定 L、化学

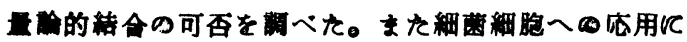
上り細胞表層の理化学的解析の可能性を格知した。 材料亡方法

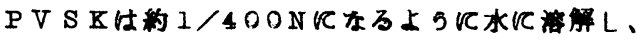

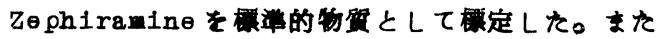

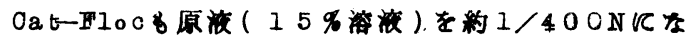

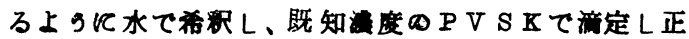

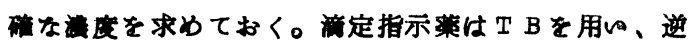

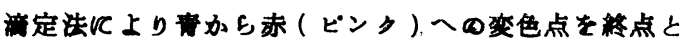

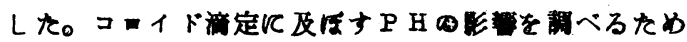
$0.01 、 0.1 \mathrm{~N}$ の $01 、 \mathrm{NaOH}$ 洨で PHを1-13

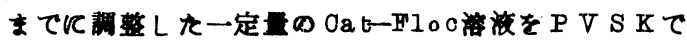

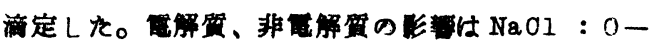
$1 \%, g l y c e r i n, g l u c o g e, s u c r o s e: 0-30$

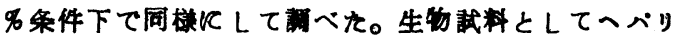
ン、 $t \rightarrow R N A($ Jeast由来)をコロイド㵝定L、これ

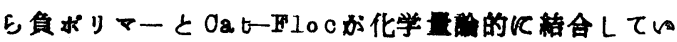

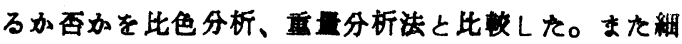

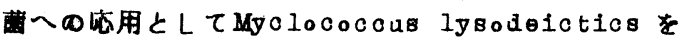

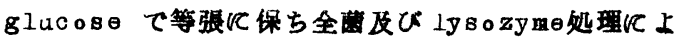
るプロトブラストのコロイド滈定を行なつた。他に 2,

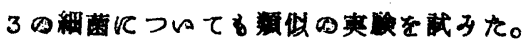

\section{結果お上ど教鿓}

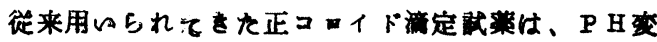

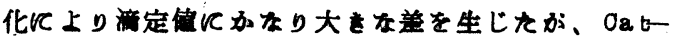
F100 P H 2-12の解で完全飞一定值を示す。

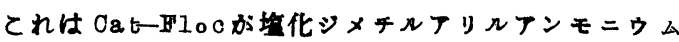
を重合させたりのであるから完全比 4 級て ミン型にな

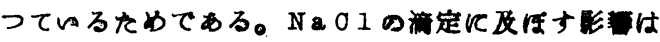
0.3 \%以上で終点の判別が不解明化なり、0.7 \%以上 では全く不可能となる。し加し非篗解でばの上う な湌度です学比鋭敏な变色を示した。したがつて細胞

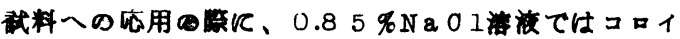
ド涪定が不可能だが gluooso 等を用的れば等热性を 保つととがでる。Oat-Flocとへパリン、tーRNA の化学昷的結会がイオゥの重至分析、リンの比色分 析の結果により証明された。とめととから、緗胞化表

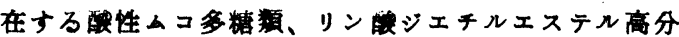

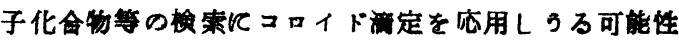
を示さするるのであろう。Myc10coocus 1ysodo lotics intact coll, protoplast

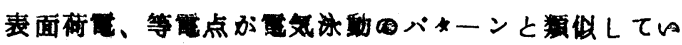

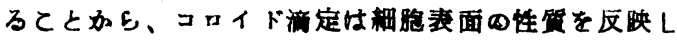
ていると思われる。また同時にOatーFloo忙菌数に比 例して結合ちるととす明らかになつた。 


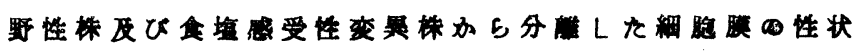

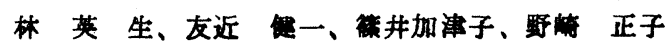

金政 弘

目的

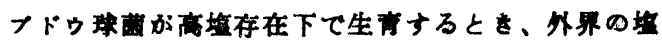

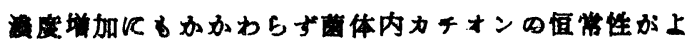

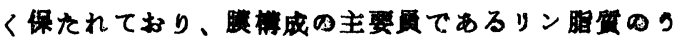
ち、カルシオリピンの含量比か著明飞增加する事実を

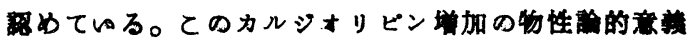

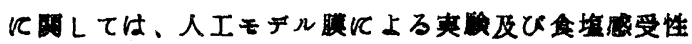

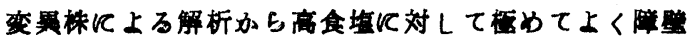

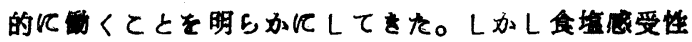

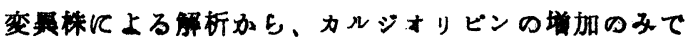

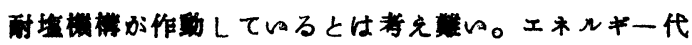

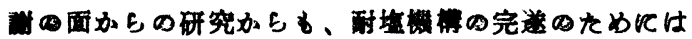

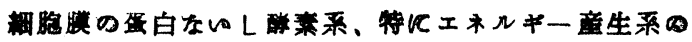

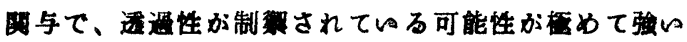

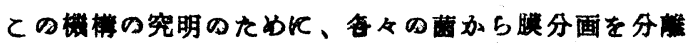

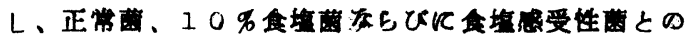

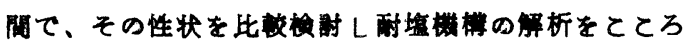
みた。

材料及び方法

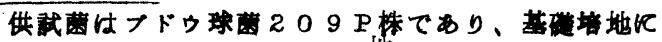

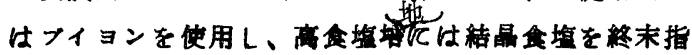

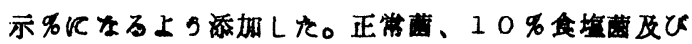

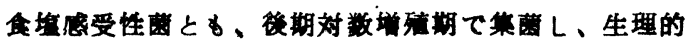

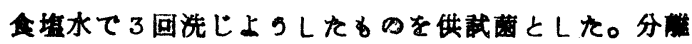

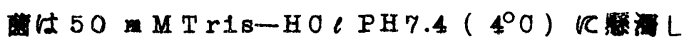

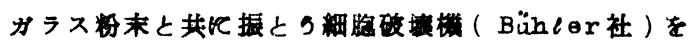

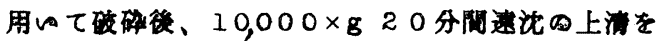
$105,000 \times 840$ 分阔速沈して膜分画を集如、同儤

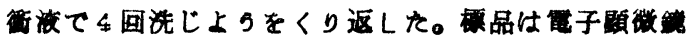

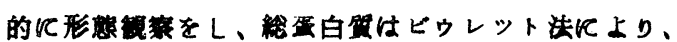

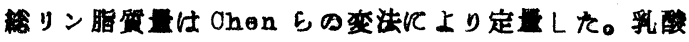

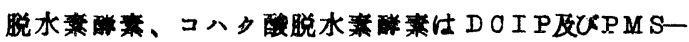
MTT法に上つた。ATPase 活性は Martin-Doty 亿上万变法て眮定した。

チトクロームの定鼓はハイドロサルフアイト塄元型と

\section{(岡山大・医・微生物)}

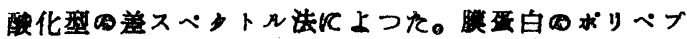

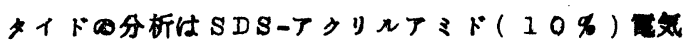

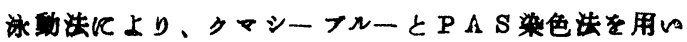
た。

結果ま上び考㭟

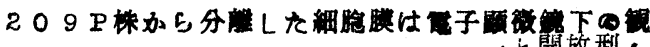

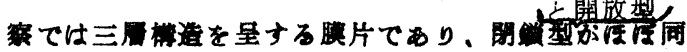

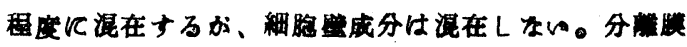
は60ー65\%が要白であり の内8 0ー90\%はリン脂筫でめつた。SDSーアクリ

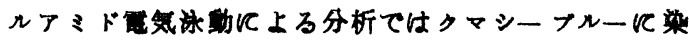
まるベントは 9 本が主愛バントてめり、分子量 6 万か

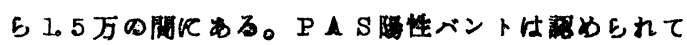

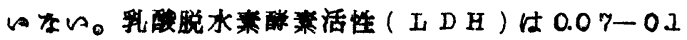

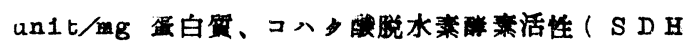
)は $0.3-0.4$ untt/ng 䍃白基てあつた。ATPase 活性怡 Mg

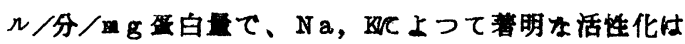

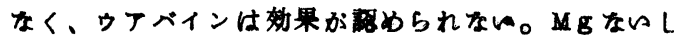

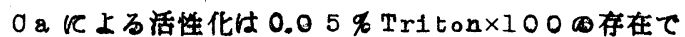

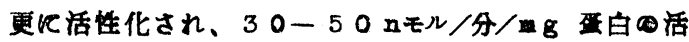

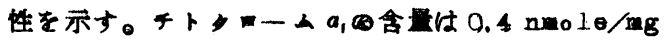
金白 $(\triangle 605-\triangle 630 \mathrm{PMM}=14.0) ， b_{1}$ 估 0.4 $\mathrm{n} \approx \Omega / \mathrm{mg}$ 监白 $(\triangle 557-\triangle 5 \eta 5 \mathrm{E}=\mathrm{M}=17.5)$

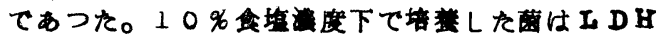
$0.1-0.2$ て正常醉上り高く、S D H $0.2-0.3 \tau$

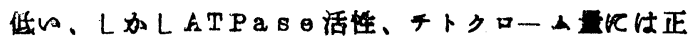

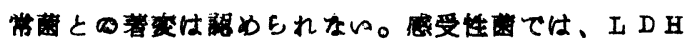

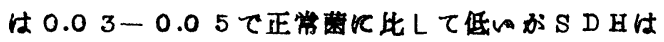
0.6ー0.8て高的活性を有する。チトクローム有仕 0.26 で少く、b、は0.75 で正常菌上り高的含量示

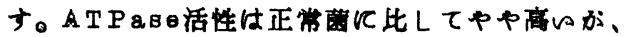
Triton添加保上万最大活性は同程度である。ペブタ

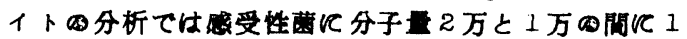

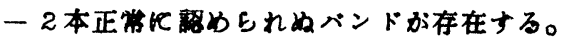

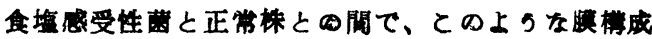

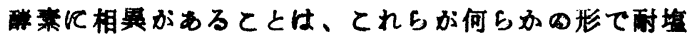

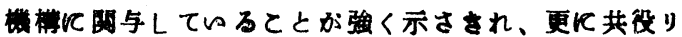

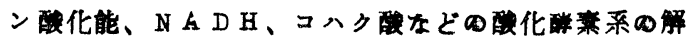
析て、上り明整比されると考えられる。 


\section{$F-1-3$}

グラ陰性中等度好塩菌外膜成分

の食塩濃度による変化

\section{平松 卓, 大野佳美, 矢野郁也, 増井正幹}

且的 グラム陰性中等度好塩菌 101 株は至適の 発育に2 M NaClを必要とし、1〜4 M の広範囲 にわたる発育食塩域を有する好塩菌であり(1), 高 濃度食塩環境への適応や、膜構造と機能の解明に は極めて好適な材料と考えられる。我々は昨年ま ず至適発育食塩濃度で培盖した菌体から外膜を調 製し、その組成（アミノ酸、リン脂質および結合 脂質）を調べて報告したが(2)，(3)，さらにてれら外 膜成分の機能を詳細に検討するために種々の食塩 濃度特に発育限界域（上限および下限）での菌体 から外膜を調製し、その組成が食塩環境に応じて どのよらに変化するかを検討した。

方法 $2 \mathrm{M} \mathrm{NaCl}$ 含有液体培地で $37^{\circ} \mathrm{C} 40$ 時間 発育した菌体を用い、20\%䓞糖中で溶菌を防ざな がら脱塩し、mureinoplastより外膜を単離し、 C SCI 浮上密度遠心法で精製を行なった。

得られた主要画分（ $d \div 1.3)$ を回収してての ものにつを加水分解後、ジアミノピメリン酸を指 標としてアミノ酸分析によりpoptidoglycan の混在を調べた。またタン白はLowry法、へキツ サミンはBIix法, 還元糖はSomogyi-Nelson 法,リンはAllen法, ヘプトースはSinilova 法によって定量を行なった。さらにFolch法に 上り extractable Iipid 抽出した後、3 N 一HCIKょりbound Iipid 抽出し、全菌、 cell envelope 敊よび外膜についてそれぞれ 定量し、その構成脂肪酸を薄層クロマトグラフィ 一およびガスクロマトグラフィー、質量分析計に より分析した。また ${ }^{14}$ アミノ酸および醋酸を培 地中に加えて培養し、膜成分中へのとりてみにつ レても検討を行ない、各種食塩濃度下における膜 の代謝についても解析を行なった。

結果および考察 至適発育食塩濃度で培盖され た菌より分離された外膜について peptidoglycanの混在を調べたとてろ、ジアミノピメリン酸

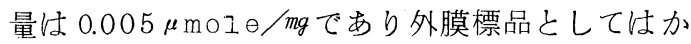

なり満足すべをすのであるととがわかった。な⿰ アミノ酸分析で沬酸性アミノ酸含量が高く、シス チンは検出されなかった。

乙の外膜標品はタン白質約 $30 \%$ 含む俰か全 脂質量が $60 \%$ 以上志占めているのが大をな特色 で、リン脂質としてカルジオリピン（CL）、ホス ファチジルエタノールアミン（PE)、ホスファチ ジルグリセロール（ $P G ）$ 称よび未知の糖リン脂質 （ $P G L ）$ を含み、アミノ酸门場合と同様酸性リン 脂質の含量の高的点が持徴的である。交たてれら のらち、本菌に特異的に見出された酸性糖リン脂 質は、全菌体より b cell envelope画分に、 また更に外膜画分飞濃縮されて存在するてとが明 らかとなった。そこでてれらの膜脂質含量を種々 の食塩濃度（1３Ｍ）で発育させた菌体につ的て 調べたところ、PGL含量注、本菌が至適発育をす る2M末で注塩濃度と共に增加し、それ以上の 濃度ではほぼ一定しているととが見出された。2 $-14 \mathrm{C}$ 醋酸の各脂質へのとりとみも食塩濃度により 著しく異なり、高濃度食塩下ではPGLへの極め て多量のとりてみが認められた。

一方、本菌よりWestpha工法に準じて抽出した リポ多糖および外膜のbound Iipid中の脂肪酸 江炭素数 10,12,14の短鎖のものが多く、この5 ち特に $\beta$ 一ヒドロキシドデカン酸が約 $90 \%$ を 占めているのが特徽的であり、乙れらの変動に つ๙ても検討中である。

一般に好塩性細菌の発育食塩濃度を規定する因 子については種々推測されるが、上記の結果から、 少なくとも外膜成分の構造と機能が一つの要因と なっているととが示焧された。

\section{文献}

(1) MaMasui \& S.Wada :Can.J.Microbiol., 19(10), 1181,1973

(2) 増井正幹：日細誌 299 (2), 408, 1974

(3) 平松, 大野, 矢野, 增井 : 生化学 46 (8), 483, 1974

(4) Y.Ohno, I. Yano \& M.Masui : FEBS in the press 
ボツリヌス菌の膜采の再構成に関する研究、とくに再構成に及にす $\mathrm{M}^{2}+$ と 細胞質成分の影響

増田邦義. 古賀哲郎. 川田十三夫 (徳大 ·医。栄盖衛生)

\section{要約}

1. 膜画分をS D S で可溶化後、 $\mathrm{Mg}^{2+}$ 無添加で唀析 した場合は既報の上うに膜は再構成さされず小桿状体

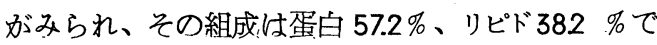
もとの膜に近い。

2. $0.5 \mathrm{mMM} 2+$ 存在下での诱析では小桿状体に膜が 張られ、小胞加形成され、その組成は蛋白 $36.9 \%$ 、 リピド57.0\%でリピド量がかなり高い。 $\mathrm{M} g 2+$ 濃度 の増加と共に再構成膜は大きくなり、蛋白含量が増 加し、 $30 \mathrm{mM}$ ではもとの膜組成に质ら゙等しくなる。

3. 可溶化膜液は $M g 2+$ 無添加で $260,000 \times g$ 超遠 心により膜が再構成され、その組成はもとの膜に疨 ら゙等しい。

4. メソゾーム画分を音波破壊後トリプシン処理し可溶化 したものは、細胞質膜画分の場合のような大膜片が 再構成される。

5. 細胞質膜可溶化液に微量の可溶性細胞質成分を添 加すると大膜片は形成されない。

目的

$\mathrm{A}$ 型ボソリヌス菌より既報のように分離した細胞質膜 とメソゾーム画分をドデシル 硫酸ナトリウム（SDS)で可 溶化後、S D S 除去に上り再構成される膜の形態形成 に及居す $\mathrm{M}^{2+}$ 之可溶性細胞質成分の影響を形態学的 化学的飞検封する。

材料と方法

A 型ボツリヌス菌 $190 \mathrm{~L}$ 株より既報のように自己融 解を利用して細胞質膜とメソゾームを分画し、トリプシン

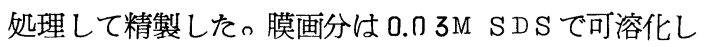
$100,000 \times g$ 1時間遠心し、その上清を再構成実験 水用的。

\section{成綪と考察}

S D S で可溶化した細胞質膜画分を $M^{2}{ }^{2+}$ 無添加の 20 倍希釈 $\beta$ 一楥衝液（pH $7.4 ）$ 飞対して诱析すると 暯は再構成されむ゙、多数の小桿状体がみられる。この 小桿状体は $260,000 \times g \quad 3$ 時間超遠心すると沋渣儿 集车り、その化学組成は蛋白（Pr) 5 7.2\%、リピド
(亡) 3 8.2\%( $\mathrm{Pr} / \mathrm{L}=1.49$ )でもとの膜組成とよく似 ている。 $0.5 \mathrm{mMM} g 2+$ 存在下では小桿状体が互いに 連なり、とれと膜が張られ小胞を形成し、その組成は $\operatorname{Pr} 36.9 \% 、$ L $57.0 \%(\operatorname{Pr} /=0.65)$ でリピド含量が 高い。RazinらのMycoplasma の膜の再構成の場合 之同様に $\mathrm{M}^{2+}$ 濃度怔増すと再構成膜の蛋白量は増加 し、リピド量は減少する。 $5 \mathrm{mMM} g^{2+}$ では再構成膜は $\operatorname{Pr} /=1.28$ であるが、なお比較的小さな小胞しか形 成されない。30mM ではもとのような大膜片が形成さ れ、 $\operatorname{Pr} 60.3 \% 、 L 37.2 \%(\operatorname{Pr} / L=1.62)$ となる。し加し 膜の再構成に $\mathrm{Mg}^{2+}$ が必須な因子ではなく、可溶化細 胞質膜液を透析を行なわずに $260.000 \times g 3$ 時間超遠 心すると沈椬に大膜片が再構成され、その組成はもと の膜とほぶ同じであった。この再構成の機構について は検討中である。

メンソゾーム画分の再構成膜についても $\mathrm{M}^{2+}$ 濃度は 同様な影響を及活すが、既報のように30 mMMg ${ }^{2+}$ 存在 下でも大きな膜片は形成されない。このようなメソン゙ 一ム画分加大をな膜片の形成されない機構を觡明す るため、化学組成を細胞質膜办らの再構成膜のそれと 比較検封したが、蛋白、リン脂質組成に著しい差はみ られなかった。メソゾームの内容物にはリボゾーム粒子な ぞが観察され、それらが膜の形態形成に影響している のではないかと考え、次のよらな実験を行なった。メ ソゾーム 画分を軽く音波破壊し、小胞内容を遊離させ た後、トリプシン処理したものをS D S で可溶化し、 $30 \mathrm{mMM} \mathrm{g}^{2+}$ 存在下で透析すると細胞質膜の場合のよう な大膜片が再構成された。また、可溶化した細胞質膜 画分に可溶性細胞質成分を袮量 (蛋白含量で 1/100) 添加するととにより、30mMMg ${ }^{2+}$ 存在下で透析しても 大膜片が形成されないととが示された。この上うな成 績はメソゾームの小胞内容物がメソゾーム膜の再構成を制 約しているととを示す。再構成膜に影響を及活す細胞 質成分や他の蛋白性物質などについて検尉中である。 
F-I-5

スピロヘータ細胞の表層構造体 "microfiber" につんて 。三㴊一三、柳原保武、服部幸男（静岡薬大・微生物）

\section{目的:}

さきに、スピロヘータ細胞の表層構造体に由来 すると思われる、径 3.0-5.0 nm の基本微粒子が linear飞結合し、かつ枝分れのある微細な線維 "microfiber" (MF) の存在するととを電顕的に 明らかにした。(J. Bacteriol.， 95，2403，1968) MF は細胞構造の保持と細胞の運動に関連する重 要な構成成分と推定されるので、その分離精製と その化学的、免疫学的性状を明らかにするととを 目的とした。

\section{方法:}

Leptospira biflexa浦和株を Baseman-Cox 合成培地飞培養、菌体を集菌、 $1 \mathrm{~N}-\mathrm{NH}_{4} \mathrm{OH} ， 3 \mathrm{hr}$ 処理後、遠心 $(12,000 \mathrm{~g} \times 1 \mathrm{hr})$ 分離し、次に超 音波破壊 (30 Kc/sec) を 3 分間行つたのち、遠 心 $(12,000 \mathrm{~g} \times 1 \mathrm{hr})$ し、細胞表層膜成分を集め た。乙れに Hyaluronidase $(0.5 \mathrm{mg} / \mathrm{ml})$ を0.1M 酶酸 buffer中で $37^{\circ} \mathrm{C}, 24 \mathrm{hr}$ 作用後、(12,000 g x1 hr) 遠心し、その上清をコロジオンバックを 用いて、1/5 容量に濃縮し、ふたたび $12,000 \mathrm{~g}$

$1 \mathrm{hr}$ 間遠心した。乙の上清をさらに 263,000g $5 \mathrm{hr}$ 間超遠心し crude microfiber 画分を分 離した。次にこの粗画分を $\mathrm{RbCl}$ 密度勾配遠心分 離 ( $\left.\mathrm{RbCl} 108-40 \% ， 73,000 \mathrm{~g} 24 \mathrm{hr} ， 5^{\circ} \mathrm{C}\right)$ C゙ MFを含むbandを分離し、さらに精製するため Sepharose 4B ゲル濾過分離を行つた。この精 製 MF について SDSーデイスク電気泳動で純度を 確認し、化学分析玉たゲル内沈降反応によつて免 疫学的性状を検討した。

\section{結果:}

$\mathrm{RbCl}$ 密度勾配遠心法によつて、2つのピーク (PI，PII )が得られ、 $\rho=1.175-1.85 \mathrm{~g} / \mathrm{cm}^{3} の$ PI は大部分が蛋白で、 $\rho=1.275-1.285 \mathrm{~g} / \mathrm{cm}^{3}$ のPII は糖と蛋白から成つていた。電顕観察によ つて MF は、PII 部に存在するととを認めたが、 夾雑物が認められるので、さらにSepharose 4B
ゲル濾過による精製を行つた。その結果、MFを 含む voidvolume 附近で溶出してくるピークと broad な゚ークに分かれ、前者を凍結乾燥して MF 精製標品とした。MFは糖と蛋白質の含量が 1:1で、ガスリキッドクロマトグラフイー GLC により中性糖として、フコース、アラビノース、 キシロース、マンノース、ガラクトース、グルコ ースが同定された。アミノ酸組成については目下 追求中である。

さらに MFを SDSーデイスク電気泳動（78アク リルアミドゲル、 $100^{\circ} \mathrm{C} ， 3$ 分間処理）を行つた 結果、BCB 染色、PAS 染色共飞陽性の 1 本のバン ドが得られ、このととからす MF は糖蛋白と推定 された。また MFの subunitの分子量は、約 7 万と推定された。L.biflexa 抗血清に対して ゲル内沈降反応を行らと、精製 MF は一本の沈降 線を形成し、L，biflexaのSDS 抽出抗原によ る沈降線のうちの一本と完全に fuseしている。 また pronaseを 24 時間作用すると MF は消失 する。

\section{考察:}

MF は糖蛋白と推定され、そのconformation と、その機能の面から興味深いものである。MF は分離したprotoplasmic cylinder(PC)加 のみ出現し、このととから PC 表層部において、

MF は cell wall 覆つて存在しているるのと 考えられる。 
目的先に我々は、PO寒天培地 * 継代保存し た Micrococcus Lysodeikt icus IFO 3333 対数増殖 期の菌が、緩衝液に懸濁すると細胞壁自己融解現象を 示し、この現象が、反応系にトリブシンを添加すると とにより阻止されるとと、細胞壁溶解酵素活性は主と して細胞質膜画分に認められるととを述べ、更に この菌をNPG 寒天培地 * 飞継代培盖すると、自己融 解を起とさない変異株が得られるととを報告した。* 以下述べる研究では、自己融解現象及び関与する 自己融解酵素の生理的意義を細胞の増殖と関連つ けつつ、解析しょらとした。

材料之方法 1 か月每に継代され.た前. Iysodei一 kticus IFO, 3333 の原株（PO株）と変異株（N PG 株）とを用いた。両株共、NP液体培地 *で $37{ }^{\circ} \mathrm{C}$ て 振燙培養した。自己虽解の有無、程度は、冷水て 2 回洗浄した全菌体を、0.01M リン酸緩衝液( $\mathrm{pH} 7.5)$ に眯濁し、 $37{ }^{\circ} \mathrm{C}$ 保温して OD550の変化、及び必要 に応じグム染色性を追うことによって調べた。

結果（1）PO株の集落は粘稠性を示すが、トリプシ ン又は DNAase I を添加した培地上の集落には、粘稠 性は認められなかった。一方 NPG 株の集落は粘稠性 を示さなかった。(2) PO株は固形、液体培地のい ずれにる、単個細胞として散在して増殖するのに 対し、NPG株は固形、液体培地のいずれで培養した 場合にも、細胞が tetradを形成するのが観察され た。(3) NP培地にトリブシンを加えて培養したPO 株は、トリブシン無添加 N P培地増殖菌とは異なり、 対数增殖期においても自己融解を示さなかった。 しかしトリブシンの添加は、増殖曲線及び菌の形 態飞は無影響だった。(4)一方 NPG 株では、トリ プシン入りのNP培地に培養したとてろ、トリブシ ン無添加培養の場合とは異なり、極めて大形で、 網目状の隔壁を示す細胞“集団”の出現が観察さ れた。なお N P 培地、或いは菌懸濁液へトリプシン を添加しても自己融解は認められなかった。 (5) PO株の対数增殖期、静止期、NPG株の対数増殖期
の菌体から得た細胞壁ぺブチドグリカンの組成、 $\mathrm{N}$ 端並びにC端アミノ酸の分析值については、と れ迄のととろ有意の差を認めていない。

考察“細胞壁自己融解現象はんくつかの菌種の 対数増殖期の菌について観察され、乙の現象に与 る細胞壁自己融解酵素が細胞の生長と分裂 (分離) に 重要な役割を演じているととが多くの研究者により指 摘されている。現在までに報告されている自己融 解酵素は、いずれる細胞壁ぺブチドグリカンを水解す るすのであるが、菌種により、この酵素の種類数、活 性の強さ、切断する結合の種類や細胞に和ける存 在場所はまちまちである。更に対数増殖期の菌に自 己融解現象が認められない菌種も少なくない。亦 た(3)で述べた所見は、との現象ないしは関与する 酵素が細胞の増殖とは少なくとも直接的には関係 ないととを示狻している。以上一見矛盾すると思 える知見を無理なく説明するには、次の解秎が適 当ではないかと考える。「細胞分裂の進行と共に 隔壁形成部位で合成された新しい細胞壁は周辺部 へと移行する。同時に、隔壁部位で娘細胞をつな ざとめている細胞壁の切断といら生理的役割を果 たし終えた細胞壁自己融解酵素も周辺部へ移行す る。との過程で、上記酵素は周辺部 (Periplasmic region)飞存在するトリブシン様の酵素で不活性 化される。細胞壁自己融解現象は、乙の不活性化 機構の不完全な菌におらてのみ、たまたま観察さ れる現象であり、生理的役割を果たし終えた細胞 壁自己虽解酵素によって引き起てされるのである。」 ての考六に従らと、(4)で述べた所見は、まだ生理 的役割を果たしていない細胞壁自己融解酵素活性 がトリブシンにより抑制された結果として現われ た現象と言えよう。なおての所見は、分裂の過程

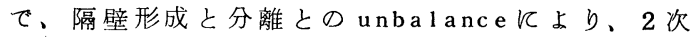
元的な拡がりをるった細胞“集団”が生じる事を 示す点で注目を引く。*第46 回日本生化学会 大会抄録, 生化学, 45(8):454(1973)。 
$F-1-7$

食塩飢餓状態における腸炎ビブリオ・リボソームの動態

森下日出旗（大阪市環科研・微）, 増井正幹（大阪市大・医・細菌）

目的, 腸炎ビブリオはその発育に特異的に Na イオンを要求するが, との要求性を解明するため $\mathrm{Na}$ イオンの存在下と非存在下の比較により検討 するととから始めた。今回はリボソームの合成と 構造変化について, 若干の知見を得たので報告す る。

方法, 材料はVibrio parahaemolyticus, A - 55 を使用した。培地は合成培地を使用し, $37{ }^{\circ} \mathrm{C}$ で振温培養を行った。蛋白合成, 核酸合成 は常法の放射性前駆物質のとりてみにより測定し， リボソームは庶糖密度勾配遠心, $105,0000 \mathrm{~g}$ 90 分により, R N A D E A E セルローズ・カラムで分析を行った。

結果および考察, 腸炎ビブリオは生長および蛋 白合成に Naイオンの必須的要求性を示し, $\mathrm{Na}$ イオンを除去すると生長も止まり，蛋白合成はみ られなくなるそして，r-R N A の合成も阻害 され,リボソーム合成屯阻害をうけた。一方, 低 分子の R N A 合成はみられた。そして細胞にとっ て Naイオンの飢餓の状態が 15 時間を経過する と, 細胞内においてリボソームの構造に変化がみ られ， 70 Sリボッームが消失し，50 S ， 30 Sの亜粒子が增加した。乙の食塩飢餓 15 時間後 $\mathrm{Na}$ イオンを再添加すると回復生長がみられた。 この生長で 3 時間の Iag phaseがみられ，乙 の lag phaseでは蛋白合成が R N A 合成より先 行し, 新しいポリリボソームの形成がみられた。 そして生長の進行ととあに, 食塩飢餓 15 時間で 解離した $50 \mathrm{~S}, 30 \mathrm{~S}$ 亜粒子の解合がわずかに みられた。

これらのととから，腸炎ビブリオにおける $\mathrm{Na}$ イオンの要求性の一因として,まずリボソーム蛋 白の合成への関与が示唆された。 


\section{目的}

細菌の蛋白合成系に阻害作用を示す大部分の抗 生物質はグラム陽性菌に有効であるにも拘らず, グラム陰性菌すなわち大腸菌の無細胞蛋白合成系 を用いて，その楽剤の詳細な作用機構の解析がな されているのが現状である。大腸菌の無細胞系で 得られたその知見が, グラム陽性菌における楽剤 の作用機構と一致するのかどらか比較検討する必 要がある。

そとで私達は, グラム陽性菌のらちでもとくに ブドウ球菌（ブ菌）につんて，アミノ酸とりとみ 効率のよい無細泡蛋白合成系を得るべく研究を進 めて来た。

ブ菌における無細胞蛋白合成采は大腸菌で確立 された系と同一の条件では酸不溶分画へのアミノ 酸とりこみ活性が低い。乙の原因を明らかにする ため,すなわちブ菌の無細胞系と大腸菌のそれと の差異について比較検討した。

私達は poly A 依存 polylysine 合成系 (poly lys 合成柔) ではブ菌のS-100 分画 $(105,000 \mathrm{~g}$ 上清）は大腸菌のそれに比べて活性が低く，その 活性の低い原因のひとつが Iys-tRNA 形成反応段 階にあるととを明らかにし; 第 47 回本総会で報 告した。

一方, poly U依存 polyphenylalanine 合成 系 (polyphe 合成系) ではブ菌リボソームが大腸 菌リボソームに比べて, 反応系に高濃度の poly Uを必要とするととを見いだし，その原因として リボソームと poly U の親和性が大愓菌リボソー ムに比べ低いためであることを支持する結果を得 た。

\section{方法}

ブ菌 209p 株, U9 株, U9NO株㧅よび大腸菌 Q-13 株よりリボソーム分画小よび S-100 分画を MAO ${ }^{1)}$ の方法により調製した。リボソーム分画は 更に $1 \mathrm{M}-\mathrm{NH}_{4} \mathrm{Cl}$ 支含む $\mathrm{HEPES}$ 緩衝液で一夜透析し,
洗棥リボソームとして用いた。

各菌株のそれぞれの分画について組合せあるい は組換え実験により poly U又は poly A 依存ポ リペプチド合成活性を比較検討した。 又,リボソームとメッセンジャー，すなわち poly U 又は poly A との親和性についてはニト ロセルロース法 ${ }^{2)}$ による binding assayおよび 庶糖密度勾配遠心法により検討した。

\section{結果および考察}

ブ菌無細胞系における polyphe 合成活性は土 ッセンジャ一濃度を大腸菌の場合よりす増してゃ る（約 10 倍）ととにょり, 大腸菌の polyphe 合 成活性と同レベルをで促進された。

このようにブ菌 polyphe 合成系における高い メッセンジャ一濃度の要求性は S-100 分画は大 腸菌 S-100 と同程度の活性を有しているととか ら，ブ菌リボソーム分画の性質を反映していると 考えられる。

この著明な poly U 依存性の原因として，一つ にはブ菌リボソームの poly Uとの親和性の低下 が考えられる。ニロセルロース法又は超遠心 沈降像の解析によると, ブ菌リボソームは大腸菌 の場合に比べて，きわめて poly Uとの親和性が 低い。一方, ブ菌リボソームと poly A との親和 性は大腸菌の場合と同程度であった。乙のような ブ菌リボソームの poly U又は poly A 亿対する 親和性の差異はアミノ酸とりとみ活性の差異にも 対応しているととから, poly-phe 合成系におけ るブ菌リボソームの性状が大腸 菌リボソームと 明らかに相違するととが示唆された。

1) J. C. -H. MAO : J. Bacteriol. 94 80, 1967

2) M. SMOLARSKY and M. TAL : B. B. A. $\underline{199}$ 447-452,1970

* 現星楽科大学微生物学教室 


\section{G-I-I}

酵素

\section{PSEUDOMONAS AERUGINOSA の GELATINASEK} 関する研究

○楢崎治彦, 山中太木（大阪医大・微生）

\section{目的}

Pseudomonas aeruginosa (Ps. a.)の Gelatinase (G. )に関する知見は未検討の問題が山積しているので 遂時解明を期したい。

まず本報告では特にPs. a. Na.5より得た G. の分離 精製法について述べる。

\section{方 法}

Ps. a。N. 5 のブイヨン培養液（ $37^{\circ} \mathrm{C} \times 2 \sim 4$ 日）を遠 心, 上清を濾過し, $37^{\circ} \mathrm{C}$ 減生濃縮。濃縮液をSephadex $\mathrm{G}-75$ (Sd. G-75) カラムを通し, 最初に溶出する淡 黄色 $\mathrm{G}$ 活性画分を $\mathrm{CM}$-cellulose カラムに通す。次い でDEAE-cellulose カラムに吸着させ, $0.1 \mathrm{M} \mathrm{NaC1}$ linier elution。溶出したG. 活性画分を透析し, 再び DEAE - cellulose カラムに吸着させ, 同上条件で溶出 する。この G. 活性画分を Sd. G一75 カラムに通し溶媒 を稀発性 buff.と交換し, 凍結乾燥した。

G. 活性はX線フィルムの gelatin 溶解をみる逢坂氏 法で測定した。

Ca sein 分解活性 (C.活性) は Casein - 275 吸収法で 测定した。

G. 溶液を $100^{\circ} \mathrm{C}, 80^{\circ} \mathrm{C}, 60^{\circ} \mathrm{C}, 48^{\circ} \mathrm{C}$ 及び室温でそれ ぞれ 10 分処理し,またEDTA. Iod-acet., Cysteine 各 $10^{-3} \mathrm{M}$ を添加し，それぞれのC活性を測定した。

電気泳動はSeparax, $0.5 \mathrm{~mA} \times 60$ 分, 0.1 M Phosph. -buffer, Ponceau $3 \mathrm{R}$ 染色で行った。

\section{結果及び考察}

培養経過とともに G. 活性は増加し， 3 日後にはX 50 となる。

Sd. G-75 カラムは淡黄, 黄, 黄緑, 緑色のバンドを 形成し, G. 活性は㷋黄色バンドにみられた。

$\mathrm{CM}$ - cellulose カラムは G. 活性部分をほとんど吸着 せず，大部分は 1.5 倍容量となって溶出する。

First DEAE-cellulose カラムは淡黄, 黄, 黄褐, 茶 褐, 灰褐, 濃褐色のバンドを形成し, G. 活性画分は淡
黄色バンドで NaCl $0.05 \mathrm{M}$ 以下で溶出する。

Second DEAE-cellulose カラムでは G. 活性成分が 対称形の鋭いピークとなって溶出する。

G. 溶液を温度処理し C 活性をみると， $48^{\circ} \mathrm{C} \times 10$ 分 ではほとんど失活せず， $60^{\circ} \mathrm{C} \times 10$ 分で約 $20 \%, 80^{\circ} \mathrm{C}$ 以上では $100 \%$ 失活した。また,10-3M EDTA, Iodacet.,Cysteine添加ではほとんど影響がなかった。

G. の Casein-275 吸収による至適 PHは 8.2 で, 6.2 〜 9.8 で 50 \%以上の活性がある。逢坂氏法では PH 7.0 からアルカリ側にかけて急激に活性が増加し PH 9.0で も低下しない。これはアルカリ条件でGelatinに直接 作用して分解されやすい状態になるためと思われる。 電気泳動のみかけの移動距離はPH 5.8, 6.85, 7.8 でそれぞれ $-4,-1,+0.5 m m$ でいずれも単一の spot である。 


\section{G-I-2}

各種緑膿菌およびグラム陰性桿菌の

エラスターゼ, プロテアーゼ産生性

五島瑳智子, ○小川正俊, 金子康子, 滝田聖親, 堂崎 勲 多田生三, 桑原章吾 (東邦大・医・微生物)

目的

緑膿菌の産生するプロテアーゼおよびエラスターゼ が病原性と関連するととは角膜感染について報告され ている。乙の性状と緑膿菌の他の生物学的性状の関連 をしらべる目的で緑膿菌の新鮮分離株および一部の性 状を異にする菌株の両酵素の産生性を調へ， マウス実 験感染における菌力との関連につんても検討した。 方法

培地：プロテアーゼの場合は，カゼイン $10 \mathrm{~g}$, クエン酸ナトリウム $4.41 \mathrm{~g}, 1 \mathrm{M} \mathrm{CaCl}_{2}$ 液 $20 \mathrm{~m} \ell$ ，標 準寒天培地(酵母エキス $2.5 \mathrm{~g}$ ，ペプトン $5 \mathrm{~g}$ ，ブドウ 糖 $1 \mathrm{~g}$ ，寒天末 $15 \mathrm{~g}$ ) を精製水 $1,000 \mathrm{~m} \ell$ 亿加元加温溶 解し, PH 7.2 亿調整したるのを $120^{\circ} \mathrm{C} 15$ 分高压隇 菌後 $50{ }^{\circ} \mathrm{C}$ 保ち, 隇菌塩化カルシウム液 $20 \mathrm{~m} \ell$ を加え て十分混和する。

エラスターゼの場合は, $\mathrm{A}$ 液 $\left(\mathrm{K}_{2} \mathrm{HPO}_{4} 25 \mathrm{~g}\right.$, $\mathrm{KH}_{2} \mathrm{PO}_{4} 25 \mathrm{~g}$, 精製水 $\left.250 \mathrm{~m} \ell\right), \mathrm{B}$ 液 $\left(\mathrm{MgSO}_{4} \cdot\right.$ $7 \mathrm{H}_{2} \mathrm{O} 10 \mathrm{~g}, \mathrm{NaCl} 0.5 \mathrm{~g}, \mathrm{~F} \Theta \mathrm{SO}_{4} \cdot 7 \mathrm{H}_{2} \mathrm{O} 0.5 \mathrm{~g}$, $\mathrm{MnSO}_{4} \cdot 4 \mathrm{H}_{2} \mathrm{O} \quad 0.5 \mathrm{~g}$, 精製水 $250 \mathrm{~m} \ell$ ), C 液 (Elastin $10 \mathrm{~g}$, 精製水 $100 \mathrm{~m} \ell$ )。 水 $90 \mathrm{~m} \ell, \mathrm{A}$ 液 $0.5 m \ell$, B 液 $0.5 m \ell$, C 液 $10 m \ell$ を溶解し, Elastin が均一に眯濁された状態になるょうに擋䢁し, シャー レに分注。

接種菌：HI brothで $37^{\circ} \mathrm{C} 16 \sim 20$ 時間培盖 したすのをdisc（８ｍ/m厚手, 東洋沪紙）にしみとま せ, 寒天平板にのせる。

判定：プロテアーゼは $37{ }^{\circ} \mathrm{C} 24$ 時間後に判定, disc の周囲に白色沈䍩環を形成した。のを陽性と判 定した。エラスターゼは $37{ }^{\circ} \mathrm{C} 7$ 日後に判定, エラス チンを溶解し透明環を形成したすのを陽性とした。

\section{結果および考察}

プロテアーゼ産生は緑脤菌のメラニン株,ムコイド 株, 無色株, その他の色素産生株との間にあまり差が なく，との菌す80\%以上が陽性であった。エステラ 一ゼの場合は, 無色株 $0 \%$, メラニン株 $25.6 \%$, ムコ イド株 $47 \%$ ，その他の色素産生株は $42.5 \%$, 新鮮臨
床分離株 $80.4 \%$ で新鮮株におけるエラスターゼ産生率 がもっとも高く, メラニン株, 無色株が低い傾向を示 した。緑膿菌以外の菌では，A，cloacaeはェラスタ 一ゼ0\%, プロテアーゼ $86.6 \%$, Serratia エラス ターゼ $20 \%$, プロテアーゼ $100 \%$, Pseudomonas 属ではP. maltophilia はエラスターゼ74\%, プ ロテアーゼ100\%, A. xylosoxidans はプロテア 一ゼ $37.7 \%$, Acinetobacter anitratus はプロ テアーゼ $95 \%$ 陽性であった。

緑膿菌の産生するエラスターゼ，プロテアーゼは眼 角膜感染と密接な関連があるとされているが, マウス 実験感染において菌力の強い株が必ずしるエラスター ゼを産生せず，また敗血症など全身感染由来の緑脤菌 が必ずしもェラスターゼを産生しない。新鮮分離株で はプロテアーゼ, エラスターゼ共に陽性株が多いが, 同一株における新旧株の陽性率の比較和よび生物活性 などにつんてはさらに検討を続けたい。 
目的

臨床材料から分離されるブドウ糖非躌酵グラム陰性 桿菌の中, Amidaseを産生する数菌種につんて, Ami一 $\mathrm{d} a \mathrm{~s} \theta$ の性状の差を検討し報告してをた。

今回は, 各菌種のAmidaseに対する阻害, および誘 導について実験を行ない, 菌種にょるAmidase性状 の特街を比較した。

方法

前回同様 P.aeruginosa, P.cepacia, A. xylosoxidans, A.faecalis, A.odorans $\odot 5$ 菌種とし，基質はAcetamide, Propionamideを使 用した。

尿素による阻害作用は普通寒天 20 時間培養菌を, リン酸緩衝液で集菌, 同一条件て 2 回遠沈洗浄をくり 返し, 湿菌 $1 \mathrm{~g}$ を $30 \mathrm{m \ell}$ のリン酸緩衝液に再浮遊した ものを用いた。

AcetamideおよびPropionamideによる誘導作用 の検討には， $1 \ell$ 当をり $\mathrm{K}_{2} \mathrm{HPO}_{4} 7 \mathrm{~g}, \mathrm{KH}_{2} \mathrm{PO}_{4}, 3 \mathrm{~g}$, $\mathrm{Na}_{3} \mathrm{C}_{6} \mathrm{H}_{5} \mathrm{O}_{7} \cdot 2 \mathrm{H}_{2} \mathrm{O} 0.5 \mathrm{~g}, \mathrm{MgSO}_{4} \cdot 7 \mathrm{H}_{2} \mathrm{O} 0.1 \mathrm{~g}$, $\left(\mathrm{NH}_{4}\right)_{2} \mathrm{SO}_{4} 1 \mathrm{~g}$, Casamino acids ( Difco Technical ) $10 \mathrm{~g}$, ブドゥ糖 $10 \%$ 溶液 $20 \mathrm{~m} \ell$, 寒天 $15 \mathrm{~g}$ の培地とこれに0.01 MのAcetamideおよび Propionamideを添加した培地で，20時間培養後， 前述の方法で洗净し, 湿菌 $1 \mathrm{~g}$ を $100 \mathrm{m \ell}$ のリン酸緩 衝液に再浮遊したすのを用いた。

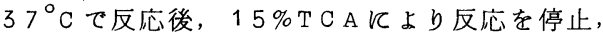
3000 r.p.m 215 分間遠心し, 上清中の遊離 $\mathrm{NH}_{3}$ を ネスラー試楽により発色させた後, 直ちに $475 \mathrm{~m} \mu$ で 吸光度の変化を測定した。

\section{結果および考察}

阻害作用：P.aeruginosaでは尿素 $0.1 \mathrm{M}$ を作用 させた場合, Acetamideおよび Propionamideのい ずれにおいてす反応 60 分までは $100 \%$ の阻害がみら れ, $0.01 \mathrm{M}$ の場合は60分て Acetamide $65 \%$, Propionamide $100 \%$ の阻害を認めた。

P.cepaciaでは60分で $0.1 \mathrm{M}$ の場合, Acetamide
で94\%, Propionamideで100\%の阻害を示し, $0.01 \mathrm{M}$ ではAcetamideに対し $58 \%$, Propionamideに対して96\%の阻害を示した。Pseudomonasの 2 菌種のAmidase では尿素による阻害のパターンは 類似している。

A.xylosoxidansでは, Acetamideに対して対照 が 4 時間目より急激に上昇するのに対し尿素を加えた 場合，時間的なずれが認められた。0.1 Mの場合はほ とんど分解が認められなかった。Propionamideに おらてる尿素による阻害作用がみとめられたが， Acetamideのパターンとは異なる。

A.faecalisとA.odoransでは, 0.1 Mの場合, らずれのAmideに対しても弱い阻害作用を認め, 0.01 Mの場合はAcetamideに対しては阻害作用が認めら れなかったが, Propionamideに対しては微弱な阻害 作用を示し, この 2 菌種は尿素にょる阻害のパターン が類似していた。

誘導作用：P.aeruginosa, P.cepacia, A. faecalisおびA.odoransにおんてはAcetamide の方がPropionamideよりす強く, A.xylosoxidans では, この条件下では分解が微弱なため誘導作用は明 らかではなかった。これに反し，P.a日ruginosa， A.faecalisおよびA.odoransの3菌種では強い誘 導作用が見られたが，P.cepaciaではそれより弱い。 A.faecalisとA. odoransの 2 菌種は尿素による阻 害作用もAcetamide と Propionamideによる誘導も ほ汪同様のパターンを示し, 菌種間に差異を認めなか っ。

各菌種のAmidaseの尿素による阻害作用はAcetamideとPropionamideとでは阻害様式が異なる。 またとれまでの報告のように, 各種 Amideに対する分 解傾向が異なり, また菌種によっては培養温度が異な ると分解傾向が変化するととから, 各種 Amideに対し 各々異なるAmidaseの存在が考えられる。またとれ らの菌のAmidase には菌属間の特徴および, 菌種間 の差が確認された。 
混合感染能を有するロ腔内嫌気性菌の産生酵素につんて

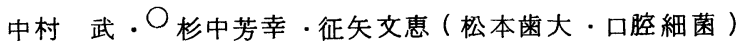

目的, heparinase産生性 Bacteroides, 嫌気性 CorynebecteriumおよびBacteroides melanin ogeni cusは歯槽膿漏症病巣局所で増量しており,また これら 3 種純培菌の組合せが種々の動物に膿瘍を形成 せしめるわれわれは今回，乙の感染能を有する菌種中， heparinase産生性 Bacteroidesおよび嫌気性 Corynebacteriumの種々ムコ多糖体に対する作用，嫌気 性 Corynebacteriumの卵黄反応因子について検討した。 方法, 供試菌は heparinase産生性 Bacteroides No.26株, 嫌気性 Corynebacterium EXC-1株である。 各菌株のムコ多糖体分解能は heparin sodium, chondroitin sulfateおよびhyaluronic acid加液 体培地に接種し, 嫌気培養後, 経日的に培養液中の基 質定量によつて検索した。なお定量法はこれまて同様 七。一 luidine blue溶液のtitrationkよつて行つた。 各菌株の培養菌体および上清から硫安分画でc日11 fre日の粗酵素を抽出し, 本抽出粗酵素による各基質分 解性を検討した。また培養の基質添加による分解活性 の消長も検した。なお酵素活性の定量は先の titra tion methodおよび平板法を用いた。平板法は各基質 $1 \mathrm{mg} / m \ell$ 加 veronal buffer中k1\% bovine albuminを添加して寒天平板を作製し, 寒天 hole中て粗 酵素を添加, 24時間incubateした後, $2 \mathrm{~N}$ acetic acidを添加して, 各抽出粗酵素の基質分解性をlytic zoneによつて検した。嫌気性 Corynebacteriumを卵 黄平板で培養すると乳光反応を示すので本反応因子に ついても検討した。まず本因子の抽出は $0.2 \% \mathrm{Y}$. E. 加 BHI brothの 5 日培養菌体および上清から先のムコ多 糖体分解酵素の抽出法に準じて行つた。抽出粗酵素の 卵黄および】ecithin 分解性は平板法およびmethanoIic NaOH溶液の titration methodで行つた。また

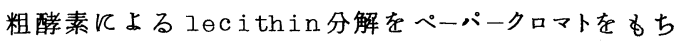
らて確認すると共にKinticsについても検討した。 成績，heparinase産生性 Bacteroidesは培養下 て hyaluronic acidの分解が経時的に緩慢な分解で あつたが供試 3 種のムコ多糖体を分解した。嫌気性
Corynebacteriumは, chondroitin sulfateおよ びhyaluronic acidの両者を分解するが heparin には作用しなかつた。一方heparinase 産生性 Bacteroidesから得た heparinase粗酵素は heparin およびhyaluronic acidの両者を分解するがchondroitin sulfaterは殆んど作用しなかつた。しか し chondroitin sulfate添加培養菌からの抽出粗 酵素中には顕著な活性を認めた。なお hyaluronic a cid分解活性は基質添加飞関係なく発現した。嫌気性 Corynebacteriumからの抽出粗酵素は先の培養下に おける分解能と同様 heparinの分解活性は認められな かつたが chondroitin sulfateおよびhyaluronic acidを明らかに分解した。これら粗酵素による各基 質の分解は平板上の Iytic zoneKよつて子確認し得后。

嫌気性 Corynebacteriumの卵黄および Iecithin の分解活性の局在を検討したとてろ培養上清中に顕著 な活性を認めた。抽出粗酵素をlecithinと作用させ， 経時的にみると明らかに滴定量が増量しており, 分解 が推定された。本反応混液の遠沈上清をぺーパークロマト したととろ phosphoryIcholiñ゙遊離が認められた。 なお対照としてCI. perfringensより得た粗酵素でる 同様であつた。次に抽出粗酵素溇度によるlecithin の分解をみると濃度に比例して商定量が増量していた。 また熱热抗性と作用至適 $\mathrm{pH}$ 検討したとてろ, 本因 子は $60^{\circ} \mathrm{C}, 10$ 分処理で活性が減弱し, 至適 $\mathrm{pH}$ 平板 法で検すると $\mathrm{pH} 6.5 \sim 7.0$ で最も顕著な反応帯が認め られた。

考察, 3 菌種組合せで感染能を有するheparinase 産生性 Bacteroides仕供試 3 種のムコ多糖体を分解 するとと，嫌気性 Corynebacteriumは heparinを 除く 2 種の多糖体の他飞 lecithinを分解する事を示 した。これらの所見から上述の 2 菌種はいうれも分解 基質域が厷範であり，てれらの属性は感染の場に当然 関与するものと考えられる。 
G-1-5

Clostridium botulinum の酵素の研究: Proteolytic enzyme I 、II の分離と性状 ( I )

○佐藤成美、田原すが、揚田富子、技重則治 (高知学園短大)

\section{目的}

Clostridium botulinum type Aより産生する proteolytic enzyme (proteinase)と esterolytic enzyme (esterase) を分離し、その性 状について報告した（1973年）。今回はproteolytic enzymeの精製を試み、type Aより更 に 2 つのprołeolytic enzymeを分離出来たの でその性状を検討する。

\section{方 法}

使用菌株：cl. botulinum type A ( 190 株) を使用した。培養：cl.botulinum type A を $\mathrm{G}$ Y P T 培地 ( $\mathrm{PH}^{\mathrm{H}} 7.2$ ) で 22 時間 $37{ }^{\circ} \mathrm{C}$ で培 養した。

酵素の分離精製：cl.botulinum type A の培 養上清を 80 \% 硫安沈澱、DEAE-、QAE-Sephadex を使用して分離精製した。蛋白分解活性 は、カゼインを基質として使用した。

\section{結果および考察}

1. $0.01 \mathrm{M}$ 一クエン酸一燐酸緩衝液（ $\mathrm{PH}$ 7.0 $)$ で 平衡化した DEAE-Sephadexには、proteolytic enzyme は非吸着、0.2M.Tris - H c I 緩 衝液 ( $\mathrm{P}^{\mathrm{H}} 9.0$ ) で平衡化したQAE - Sephadex には吸着し、1 M-Naclの gradient を行い、 カゼイン分解能を有する 2 つの proteolytic enzyme を分離した。

2. QAE-Sephaclex より gradientで溶出が先 行した enzyme を proteolytic enzyme I、後 を II と名づけた。

3. セルローズアセテート電気泳動で、陽極へ先 行したバンドは、Iであり、後のバンドは II で あった。

4. Proteolytic enzyme I、II の分子量は、そ れぞれ異なっている。

\section{考 察}

Cl. botulinum 毒素の活性化は、毒素の前駆体 に蛋白分解酵素（トリプシン）を作用させると著 明な毒カが示された。したがって蛋白分解酵素が 毒力の活性化に関与していると考えられる。 坂口らは、菌自体より産生する酵素によって毒力 が活性化されることを報告している。最近Das G UPTAらがCl. botulinum type Bより産生した PTA enzymeを作用させて、同じ type B.の前駆 体に体する毒素活性化を試みている。我々は性質 の異なる2つのProteOIytic enzymeを分離して らるので、この enzyme による性状と毒素活性化 につケて検討中である。 


\section{G-I-6}

好気化したビフィズス菌の諸性状第3 報

単個菌培養によるビフィズス菌の好気化

○立石昌義 原口怡子 中瀬安清（北研）

目的

第 46 回及び第 47 回細菌学会総会に於々 て、ビフィズス菌がしーbroth 継代により好 気化して長連鎖球菌状を径て双球菌状になる こと、それに伴ら生物学的性状ならびに抗原 性の変異等を報告した。今回は、ビフィズス 菌のMICRO-MANIPULATOR による単個菌 培盖につんて同様な変異過程がみられるかど うかを追求する。

方法

使用菌株は、B.bifidum ATCC 15696 及び B.bifidum 5529 を用いた。B L 平板に嫌気 培養したビフィズス菌の単集落をT・G・C 培地 で增殖後、M. $\cdot$. 培地（Tomarelli 液体培地）に 移LMICRO-MANIPULATOR で単個菌を採 取、M.e.培地に硫パラを重層して培養し実験 飞供した。好気化の方法は、前報子同様 B L 平板に嫌気培盖したその単集落を T.G.C 培地 で増殖後し - brothで継代を反復した。諸性 状の試験方法は前報に従った。

結果および考察

B.bifidum 5529 株をM.e.培地飞単個菌培 養したとを、4日目に増殖を始め、Lーbroth 継代 4 代で長連鎖球菌状の好気化株が得られた。 同様にこの菌株から、7 代継代で好気株が 1 株、8 代継代で 2 株、計 4 株得られた。 L-broth継代 4 代で得た好気化株中に混在し ていたビフィズス菌原株を B L平板の嫌気培 養から得たのち、B L 平板で培養を繰り返え し、好気化を試みた。乙の結果、好気化株は L-broth 継代 4 代で 1 株、 5 代で 1 株の計 2 株が得られた。

B.bifidum ATCC 15696 株の単個菌培養か 与は $\mathrm{L}$ - broth継代 1 代で長連鎖球菌状の好気 化株が得られた。

両者から得られた好気化株は、H.I.B.血液寒
天平板上飞 $\alpha$ 溶血性の集落をつくり、超薄切 片の電顕像は、前報と同様に細胞壁の消失し た連鎖球菌状を呈した。

以上の結果から、ビフィズス菌が他の菌と 挙動を供にしていると云ら可能性は、単個菌 培養による反証と、好気化時に好気化しなか つた原株からも同様飞好気化が可能である事 加否定出来る。

ビフィズス菌から Mutation によって好気の Straight rod 生ずるととは、既に 18999 年ビフィズス菌を命名したTissier 以来、 Orla-Jensen, Boventer, Weiss $\sqsubseteq$, Blauroch5によって報告され、これを parabifidusと名付けられて来た。 1950 年 Norris 5は、単個菌により、ま た Gyllenberg は branch form $の$ coccoid granuleか 5、それぞれ straight rodを得を。 このGyllenberg の示す染色標本：branched chain of short rods $は$ 、我々の得た長連鎖 球菌状の好気株と一致する。

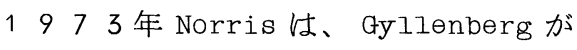
spesific contami.としたのを否定し、 Lactobacillus の contami.と推定している。 てれ等のデーターが、液体培地での継代を数 週間径て得ているのに対し、我々の実験結果 では、数代継代内に、人及び動物由来の多数 の株から、立を単個菌に上っても得られると 云う点で相違がある。NorrisのContami.説 る単個菌に上る液体培地継代で変異が得られ 固形培地での長期継代で変異が起をない事を 根拠にしている点で矛盾がある。 今後、変異の機作を明らかにし証明を試みた b。 


\section{I. 目 的}

Streptomyces 亿属する菌株において Photochromogenicity, 寸なわち, 色素合成酵素の de novo 合成が光により誘導的に開始される現 象の存在する事実については, 第 32 回日本細菌 学会関東支部総会におらて,すでに報告した。演 者らは今回, てれに関連した現象として, 暗所培 養においての夕色素合成が進行し, 明所培盖飞お いては色素産生の認められない菌株が, Streptomyces 属に存在する事実を見出した。かつる 現象については現在まで他に報告をみないので， reversed photochromogenicity と名付けてて 〉報告する。

吕. 方法

International Streptomyces Project(ISP) の保存菌株に由来する菌株より任意に 54 株を選 び本実験に供した。

前培養は $1 \%$ 糖加普通寒天培地を用いて, $27 \mathrm{C}$ で暗培養を 2 代繰り返した被検菌を，暗所で glucose-asparagin agar平板に接種し，それ ぞれを明培養と暗培盖に供した。明培養は 2 本の $30 \mathrm{~W}$ 溃光灯下 $20 \mathrm{~cm}$ の条件で連続照射のもとで培 養し, 一方, 暗培盖は遮光函中で培盖した。明培 盖，暗培盖とも $27 \mathrm{C} て ゙ 4 〜 5$ 日間培養した後， そのコロニーの色を判定した。判定後, 暗所で発 育したコロニーの着色が reversed photochromogenicityによるものか, あるいは Photolysis によるるのかを判別するため, 氷冷下 10,0001ux の光を $2 \sim 24$ 時間照射し, 呈色の変化を観祭し た。

III. 結果および考察

54 種の Streptomyces について検索した結果, 少くとも次の 4 種, すなわちS. bobili ISP 5056 ,S. flavovirens ISP 5062 ,S. corchorusii ISP 5340 および S. spectabilis ISP 5512 亿 おいて reversed photochromogenicityの存在
を認めた。これらの菌株においては，暗所培養に おいてのみ, 黄色在は桃色の色素産生が認めら れ, 明所培盖においては, てれらの色素の産生が 認められない。このととはなた暗所培盖, 明所培 養したそれぞれの菌体のアセトンーメタノール抽 出物の切飞おいても，また可視部吸収スペクト ルにおいても確認するてとができた。

かかる現象については Streptomyces 属について はもちろん, 他の細菌の色素産生に関しても報告 がみられず, 本現象の発現機構についても目下, 明らかではないが,ひと度暗所培養により発色し た菌株は, 水冷下光照射を行っても, その呈色が 消失するととはなかったので, 本現象が光分解に よるものでないととは明らかである。色素産生に 関する酵素合成系あるいはその調節系沈ける光 分解反応, または色素の生合成経路に和ける前频 体の光分解に上る色素産生の停止も本現象の原因 として考慮しうるが, 機構に関してはさらに検討 を要する。なお, 細菌の色の変動し易さならびに その記載についての混乱に関して，その原因とし ての photochromogenicity, reversed photochromogenicity, photolytic coloration photolytic decoloration とついて論ずる。 
○井内史郎. 久保田米夫. 田中修二（德島大。医。病態栄養）

目的

細菌の細胞外酵素の産生調節と cyclic AMPとの関 係を迫求している過程で、Vibrio parahaemoly七icusがデン粉を炭素源として増殖している時には培 地に加えられた cyc Iic AMPRより特て著しい増殖阻 止を受けるととを見出した。との現象とアミラーゼ 産 牛の調節との関係は現在検討中であるが、一方との現 象を利用するとペニシリン選択法に類似した原理で、し 加子加左り特異的飞CRP(Cyclic AMP Receptor Protein) 欠失変異株を選択分離でをるととを見出し たので、今回は主としてての選択分離法 (Oyclic AMP選扒法）について述べる予定である。

方法

変異の誘発は Ethylmethane sulfonate を用い て行ない、糖利用欠失の検定は $1 \%$ の糖を含むテトラ ゾリウム 寒天平板により行なつた。 CRPの定量は Perlman 等 (1970)の方法に準じ、SephadexG25 で脱塩した抽出液の 20,000 g $1 \mathrm{hr}$ 遠心上清を過剩 のAMP存在下で ${ }^{14} \mathrm{C}-0 \mathrm{yclic}$ AMP と結合させ、硫安 で沈澱させてカウントを計測した。

\section{結果执び考察}

1. V. parahaemolyticus を各種の糖を炭素源と して cyclic $\operatorname{AMP}(5 \mathrm{mM})$ を含む合成培地に増殖させ ると炭素源がデン粉、デキストリン、グリコーゲン の場 合に特に強い増殖阻止がおこる。この時菌体には光 学顕微鏡でも明らかな形熊変化がみられ、この作用 は殺菌的であり、菌の濁度は次第に低下する。

2. 野生株に変異誘発剤を作用させた後、デン粉( 0.2 $\%)$ cyclic $\operatorname{AMP}(10 \mathrm{mM})$ を含む培地に増殖させ ると短時間の後に増殖は停止しその後濁度は低下し 始める。濁度の最も低下した時に生残している菌を 集め、一度酵母エキス・ペプトン 培地に増殖させ、各 稞の糖を含さテトラゾリウム寒天培地で集落を検定す ると約 $74 \%$ の のは各種の䌅利用加同時て欠失し ている多欠失孪異株である。 Cyclic AMP 選択を 行なら前に存在するこの種の変異株は約 $0.2 \%$ 飞過
ぎないので、この選扒法により多欠失変異株が約

\section{0 倍濃縮されたととになる。}

3. 乙の多欠失変異株の糖利用欠失のバターンはすで に報告した（第４６回 日本細菌学会総会）P.TS （燐酸化的膜诱過）の場合の多欠失変異株とは異な り、グルコース、フルクトースの久失が他の糖より軽く C R P א失株として予想される特徴を示している。 又、これらの欠失はいずれる cyclic AMP の添加 で回復しない。

4. 乙の多欠失変異株の代表株 5 株について、抽出液 中の C RP 活性を測定した所、いずれ子野生株に比 べて著しい低下がみられるので、これらはＲＰ 欠 失株と考えてよい。

5.なお、残りの約 $26 \%$ ないは種々の変異株が含 まれていて、その中の1種は、多欠失性を示さない 飞もかかわらずデン粉存在下での cyclic AMP に よる増殖阻止を受けなくなつた耐性株である。その 性質については現在検討中である。

6. C RP の欠失により、デン粉存在下での cyclic AMPRよる殺菌作用を免れ、かつこれが最す多数を 占めるとい.うととは、この現象にcyclic AMP · CRP系加関与しているととを強く示唆している。 この点とアミラーゼの産生調節との関連も目下検討 中である。 


\title{
G-I-9
}

\author{
大腸菌に打けるThiamineりん酸エステルのThiamine 取込み阻害
}

西宗高弘, 中山英男, 林 良二（山口大・医・微生物）

目的

大腸菌 TDP(Thiamine diphosphate)要求性変 異株（70-23-107）の TDPによる発育はT(Thi一 amine) またはTMP(Thiamine monophosphate) で競合的に阻止される。またTMP 要求性変異株 (70-23-102) のTMPまたはTDPによる発䏍はT で阻止される。T, TMPの様な正常代謝物質による 発育阻止の現象は殆んど知られて扣らず，その機 構を解明しようとした。

方法

発育阻此の原因としては，たとえばTDP 要求性 変買株のばあい，TまたはTMPは(i) TDPを補酵 素とするある種の酵素たんぱくのTDP 結合部位を ブロックしてその機能を阻止するのか, (ii)外部添 加TDP が菌体内へ取り込まれる段階を阻止するの か，いずれかによると考えた。これらの可能性を 検討するため次の実験を行なった。即ち(i)菌体浮 遊液を用いピルビン酸を基質として消費される $\mathrm{O}_{2}$ 量が外部添加TDP に依存する条件を設定し，この 下でTまたはTMP の O 2 消費阻止の有無を検べた。 また粗酵素液を用いてピルビン酸の酸化的脱炭酸 が TDPに依存する条件を設定し本条件下でTまた は TMP の $\mathrm{CO}_{2}$ 発生阻止が起るかどうかを検討した。 (ii) 菌体浮遊液を用い glucose 存在下 TDP の菌体 への取込みが TまたはTMP で阻止されるかどうか について検討した。

\section{結果打よび考察}

1）菌体浮遊液扣よび粗酵素標品によるピルビ ン酸の酸化と $\mathrm{T}$ 要求性: 親株の 70 -2 3 株 ( $\mathrm{T}$ 要 求）を制限量の T存在下部分的嫌気条件で培養し て得た菌体内にはTDPはごく少量しか含まれて扔 らず, 本菌体浮遊液は T, TMP, TDP のいずれかを 添加したばあいにのみピルビン酸を酸化し得た。 一方, TDP 要求性変異株を制限量の TDP 存在下 で培養した菌液によるピルビン酸の酸化はTDP で は促進されるが TMP, T では促進されない。同菌液
をTDP と予温後ピルビン酸とTを加えても酸化反 応に影響はないが，Tと予温後ピルビン酸とTDP を加えると著明な阻止が見られた。一方 TDP 要求 性変異株の菌体浮遊液を音波で破壊後透析して得 た粗酵素標品は嫌気条件下赤血塩を電子受容体と してピルビン酸より $\mathrm{CO}_{2}$ を放出し得る。本反応は TDP 存在下にのみ見られT, TMP は無効であった 。此の粗酵素液をTDP と予温後 Tを加えたばあい と, Tと予温後 TDP を加えた場合とで発生 $\mathrm{CO}_{2}$ 量 に差はなかった。即ち粗酵素レベルではTによる 活性阻止はみられなかった。

2）变異株菌体に打ける T またはTMPによる TDP 取込み阻止：TDP 要求性变異株は TMP $\rightarrow \mathrm{TDP}$ 反応を触媒するTmonophosphate kinase欠損株 である。従って例えば本菌体浮遊液に glucose 存在下TDPと T を添加したばあいには両者は菌体 に取り込まれるがTはTMP となって蓄積し添加 TDP と区別することが可能となる。本菌を用いて TDP の菌体への取込みを検べると共存するTの濃 度の上昇に応じて取込みが阻止されることが判明 し, T濃度が 100 倍以上では殆んど完全にTDP取 込みの阻止が扎こることが観察された。同様の現 象はTMPを同時添加した時にも見られた。また TMP 要求性変異株に打いても TDP の菌体内人の 取込みは同時に添加した Tによって著明に阻止さ れた。

一般にTDPを補酵素とする酵素たんぱく質とTDP が結合する反応には thiazole 部の 5 位の側鎖， 末端のピロリン酸が重要な役割りをすることが知 られている。1）の実験成綪は此の知見と矛盾 しないものである。これらの知見と2）の実験結 果を総合するとT, TMPによる発育阻止は菌の生 育に外部添加 TDP ( またはTMP) が必要なばあい 培地に過剩のT(またはTMP) が存在すると TDPの 取込みが阻止されることによると考えられる。 
目的

最近のコレラ毒素研究の一つつ方向として，そ の分子の構造の解明が求められているが, 我々は 電子顕微鏡を用いてその形態を観祭し, 化学的な データから推定されているサブユニット構造との 対比を試みた。

\section{材料および方法}

毒素としては化血研の精製毒素（lot BO2）を 用いた。コレラジェノイドはやはり化血研の精製 途中の標品をSephadex 975 のカラムを通して 精製したものを用いた。純度は通常のアクリルア ミドゲル箸気泳動法によつて検したが，一応電顕 写真の解釈に誤をりを生じない程度に精製されて らるものと判断された。

試料忙 Tris-NaCl一EDTA 緩衝液 (PH 7.4) 亿 対して透析し，2\%酢酸アンモニウムで希釈等量 の2\%燐タングステン酸液と混じてカーボン膜上 にのせる通常のnegative staining 法によつ て撮影したが，電子顕微鏡としてはJEM 7, JEM 100B，またはHU12A を用い，直接倍率は5 万な らし7万倍で，それを更に10ないし５倍に引 さ伸壮して観察した。

\section{結果ならびに考察}

比較的低倍率, 低コントラストの写真では, コ レラ毒素分子は, 直径 80 ないし90 ̊程度の円 板状の粒子として観察された。しかし，粒子が小 さいため, 燐タングステン酸の層がうすく，充分 なコントラストが与えられないので，原板からの 直接引き伸ばしでは微細な構造の観察は不可能で あつたので，中間ネガを用いてコントラストをあ げ，像の輪郭をはつさりさせるととを試みた。

その結果，コレラ毒素分子恃，Y字状，U字ま たはV字状, あるいはネコの足あと様の形を示し , 粒子の長さは70ないし10 5 A, 多くのもの
は8 5 と9 $5 \AA$ ̊の間, 幅は 56 と70 ̊の間で, 少数は $40 \AA$ ○るるいはれ机以であつた。またて のよらな写真では, 明らか忆サブユニット構造が 認められ，その数は1分子あたり6 ないし7個と 考えられた。各サブユニットの幅恃約 $23 \AA$ で， 長さはそれよりもや〉長かつた。またサブユニッ トの中にはそれよりも大きいものもあつたが，写 真の上で正確に大きさ測定するととは困嚇であ つた。粒子の大をさがまちまちであり，かつ形も 一定でないととは, 粒子の形が単純でなく, また 支持膜上でまちまちの方向に並んでらることを示 しているものと考えられる。

コレラジェノイドについても, 同様な写真が得 られたが，乙の分子は，V字状交たは二等辺三角 形の粒子として認められ，その長さは平均 $76 \mathrm{~A}$ ，正面向をの粒子の幅は約 $56 \AA$ であつた。やは りサブユニット構造が認められ，毒素の場合之同 じ大をさのサブュニット6個の存在が確認された。 コレラ毒素分子は分子量約 8 4,000のタンパ クであり, 最近のデータを総合すると, 分子量約 8,0 00 のいわゆる L鎖と， 28,000 のいわゆ るH鎖とからなると考えられている。サブユニッ 卜の形を円筒形と仮定すると, 計算上, L鎖は直 径 $23 \AA$ A , 長さは $23.5 \AA$ となり, 電頻で観察さ れるサブユニットの大をさと依づ一致する。現在 までの観察では，コレラジエノイド分子は，乙の サブュニットが6個，V字状飞結合したもの，コ レラ毒素はその 2 本の腕の間に, $\mathrm{H}$ 鎖 (計算上の 大をさは 30 X 48 Aの円筒状) が壮まりてんだ ような形のY字形とするのが，もつとも合理的で あると考えられる。 


\section{C-I- 12}

破傷風毒素蛋白の構造と機能一フラグメント $\alpha$ およ゙ $\beta$ による 毒素の再構成

○松田守弘, 原 徹, 米田正彦 (阪大・微研)

目的

私どもは, 前回の総会において, 破傷風毒 素蛋白が特定の条件下で $2 つ の$ 無毒のポリペ プチド鎖（フラグメント $\alpha$ および $\beta$ ) に可逆 的に解離すること, 解離した毒素からてれら フラグメントをそれぞれ単離精製し得ること を報告した。今回の研究の目的は, これらフ ラグメントの精製標品を用いて毒素の再構成 を試み，フラグメント $\alpha$ および $\beta$ の機能を明 らかにしていくことにある。

\section{方法}

Cl.tetani Harvard A 47 株を, 肝片加肝ブ イヨンで約 16 時間培養し, ついで MuellerMiller 変法培地で $35{ }^{\circ} \mathrm{C}, 4-5$ 日間培養し自 已融解した培養沪液を出発材料とし, 硫安分 画 ( 20-40\%飽和)，超遠心分画および

Sephadex G-200によるゲル沪過によって得 た精製毒素標品を DTT(ditiniothreitol)1100mM, $25 \mathrm{C}, 60$ 分間, さらに $4 \mathrm{M}$ 尿素処理後, $2 \mathrm{M}$ 尿素 $1 \mathrm{mM} \mathrm{DTT}$ を含む緩衝液 (50 mM Tris, $0.6 \mathrm{M}$ glycine, $1 \mathrm{mM} \mathrm{EDTA}, \mathrm{pH} 8.5$ ） で平衡させた Sephadex G-200でゲル沪過を行らことによ り,フラグメント $\alpha$ おび $\beta$ の精製標品を得 た。分子量はSDSーアクリルアミドゲル電気泳 動法により測定, 抗原特異性はアガロースゲ ル内沈降反応によって解析し，毒性はCF1マ ウスを用い致死時間から村田らの方法《よっ てMLDとして測定した。

\section{結果および考察}

カラムから溶出してきた精製フラグメント $\alpha$ おび $\beta$ 標品 (それぞれ 0.22, $0.67 \mathrm{mg}$ 蛋白 /m.l）をそのます分子比が $1 ： 1$ 亿なるよう に混合し， $0.1 \mathrm{M} \mathrm{KNa}$ リン酸緩衝液 $\mathrm{pH} 7.5$ 『 対して 0 C で 24 時間攪汼なしに透析後さらに
24 時間静かに攪找しながら透析して得た標 品は, (1)アクリルアミドゲル電気泳動法でし らべると, 殆ど 1 本の, 未好理毒素と同じ分 子量 (·約 16 万)を示す蛋白バンドとして泳動 し，(2)ゲル内沈降反応において，ウマ抗毒素 血清に対して, 未処理毒素一抗毒素の沈降線 と全く融合する 1 本の沈降線を形成した。む たこの沈降線は, 抗毒素とフラグメント $\alpha$ ま たはßの間の沈降線とはそれぞれ spur をと もなって融合した。(3)精製フラグメシト標品 は，それぞれ殆ど無毒であったが，上記の透 析標品の毒性は, 相当する量の未好理毒素の それの約 $30 \%$ になて回復した。

以上の結果は, フラグメント $\alpha$ および $\beta$ が, 分子量, 抗原性, 毒性につ々て, 毒素分子全 体に対して相補的な機能をもつてとを示して らる。乙れらフラグメントの化学的, 免疫学 的性状および毒作用発現における役割につい て, 現在, 検討を加えている。 


\section{C-1-13}

ボッリヌスC 型毒素の精製及びその性状

砂川紘之 井上勝弘 ( 北海道立衛生研究所)

目的

ボッリヌス $\mathrm{A}$ 型結晶毒素は, 分子量 15 万の神 経毒と分子量約 50 万の血球凝集素から成 ${ }^{(1)}$, また, $\mathrm{E}$ 型毒素は, 分子量 15 万の神経毒及び無 毒成分を，それぞれ，1 分子ずつ含んだ複合体で あると報告されている ${ }^{(2)}$ 。

最近, 坂ロら ${ }^{(3)}$ は, 高度に精製したボッリヌス $\mathrm{B}, \mathrm{E}$ 及び $\mathrm{F}$ 型毒素をアルカリ性条件下でゲル濾 過を行ない，乙れらの毒素蛋白が，毒性成分と無 毒成分に解離するととを示し, また, 各型の毒素 成分が共通の分子サイズを持っていると報告した。 ボッリヌス $\mathrm{C}$ 型毒素は, かって首藤ら ${ }^{(4)}$ とっっ て精製が行なわれたとはんえ，その分子構造につ らては検討されていない。

我々は, ボッリヌス C型毒素 ( progenitor toxin $\left.{ }^{(5)}\right)$ の分子構造を知り, 他の型のボッリヌ ス毒素と比較するため, この毒素の精製を試みた。

材料

供試菌株は, C1, botulinum type $\mathrm{C} 203$ 株で ある。

\section{成績}

（1）ボッリヌス $\mathrm{C}$ 型菌の毒素産生用培地及び培養 条件を検討した結果，セロファン透析培養により， 培盖濾液中 $4.6 \times 10^{-5} \quad \mathrm{~L} \mathrm{D}_{50} / m \ell$ の毒素産生 が得られた。この毒性は通常培美した場合の培盖 液の約 5 倍の毒性を持つ。

（2）培盖濾液は, 硫安沈溊（，0.6 飽和 ）, $\mathrm{pH} 5.8$ の $0.025 \mathrm{M}$ クエン酸リン酸 buffer で抽出, 透析 后, 同様の buffer で緩衝化したDEAE セルロ ースカラムを通した。毒性区分は through out する。乙の区分は, $\mathrm{pH} 4.5 \quad 0.025 \mathrm{M} ク$ ク酸リ ン酸 buffer で緩衝化したCM-セファデックス カラムに吸着した。この吸着した毒性区分は, 食 塩の濃度勾配の変化によって溶出されず, 溶出液
の $\mathrm{pH}$ 変化によって溶出された。溶出 $\mathrm{pH}$ は 5.8 であった。

（3） $\mathrm{C} \mathrm{M}$ セファデックスカラムから溶出した毒性 区分は，G-200セファデックスカラム（pH5.8） で単一のピークを示した。乙の分画恃血球凝集活性 を示した。

考察

ボッリヌス $\mathrm{C}$ 型毒素の精製は, かって, 首藤ら によって行われた。彼らは, 培養濾液を塩化亜鉊 で処理し, 毒性区分を沈澱させた後, 硫安沈澱, DEAE七ルロース及びQAEセファデックスなど によってクロマトグラフィーを行ない，C型毒素 を結晶状に得たと報告している。しかし, 彼らの 精製法は, 精製過程の $\mathrm{pH}$ 条件が中性ないしは微 アルカリ性であり, 得られた標品は progenitor toxinとは考えられない。事実, 彼らの結晶標品は, 粗毒素が示す血球凝集活性を殆んど失なっている。

我々は, 坂口らの得た他の型のボッリヌス毒素 (progenitor 'toxin) と C 型菌の産生する progeni tor toxin を比較するため, 酸性条件下で C 型毒素の 精製を行なった。我々の得た精製毒素標品は, 血球 凝集素を含んでいた。現在,乙の毒素標品のアルカリ 性条件下における挙動等について検討中である。

文献

(1) Das Gupta,B.R. and D.A.Boroff, 1968 J.Biol . Chem. , 243:1065-1072

(2) Ki tamura,M. , S.Sakaguchi and G.Sakaguchi, 1968 Biochim.Biophys .Acta, 168:207-217

(3) Kozaki , S ., S. Sugi i, I.Oishi, S. Sakaguchi, G. Sakaguchi, 1974,Annual Meeting of Symp.on Bact . toxin : $47-53$

(4) Syuto, B . and S.Kubo, 1972 J ap.J.Vet.Res., $20: 19-30$

(5) Lamanna, C. and G.Sakaguchi, 1971 Bact .Re v., $32: 242-249$ 
ボッリヌス毒素の活性化と“サブュニッドん

の解裂飞つ的て

○大石 厳、阪口玄二(大阪府大・農学部)

目 的

ボッリヌス毒素の活性化は、トリプシン様酵素によ る毒力の増加として、よく知られているが、ボッリ又 ス毒素の "サブュニット” への解裂が活性化と並行す ると云ら Das Guptaらの最近の報告に関し、毒素型 および活性化の条件につんて検討した。

方法

A 型 ( Hall 株) およびB型（ｏkra 株）毒素の精 製は、第 46 回細菌学会総会で報告したF型（Lang 一e1and 株 ) 毒素の精製法と同様の方法により行なっ た。とれらの毒素の毒性成分は、DEAE-SephadexA -50 によるロマトクラフィー $(\mathrm{pH} 8.0)$ とより分離 した。

SDSーポリアクリルアミド電気泳動仕、5\%ゲルを 用々、Dunkersの方法に従い行なった。

毒力の測定は、マウス静脈内泩射法により行なった。 結果および考察

Das Guptaら火よると、E型毒素 ( 分子量約 15 万）をトリプシン処理後還元し、SDS 電気泳動を行 ならと、2つの“サブュニット”（分子量約 10 万、 と約 5 万) 几解裂するとと、蛋白分解性菌つ産生する 毒素同様に 2 つの“サブュニット”に分かれるとと から、ボッリヌス毒素の活性化は、分子量約 15 万の 毒素分子(われわれの云ら毒性成分) 鎖を切断し、2 つの“サブュニット” へ解裂するととによると報告し た。われわれは、精製 $\mathrm{F}$ 型毒素の毒力はトリプシン処 理で上昇しないが、S DS 電気泳動では土サブニニット への解裂が部分的にしか見られならととから、両者の 関係につんて検討を加えた。

蛋白分解性の A 型、B型および F 型菌は、毒素の活 性化酵素を産生するが、B型菌 ( O kra 株) は、活性 化酵素を産生するにすかかわらず、その毒素はトリプ シンでなお活性化される。そてで、てれら 3 種のボッ リヌス菌の産生する毒素を精製し“サブュニット” の解裂の程度を検討した。

$\mathrm{A}$ 型菌 ( $\mathrm{Ha} 11$ 株) を $30^{\circ} \mathrm{C}-74$ 時間培羡する
と、その培養液および精製毒素はトリブシンで活性化 されなかった。しかし、毒性成分の還元後の電気泳動 では部分的にしがサブュニット”への解裂が見られ ず、一部は解裂されずに残っていた。同様のととが、 F 型 ( L ange I and 株) 毒素次ついてす見られた。 すなわち $\mathrm{F}$ 型菌の $30{ }^{\circ} \mathrm{C}-94$ 時間培養液および精 製毒素は、トリプシンで活性化されなんが、SDS 電 気泳動では還元後でも“サブュニット”に解裂されて らなん毒素の存在が見られた。一方、蛋白分解性B型 菌 ( $0 \mathrm{kra}$ 株) の $30^{\circ} \mathrm{C}-94$ 時間培養液より精製 した毒素はトリプシンで活性化されたが、この精製毒 素から毒性成分を分離し、S D S 電気泳動を行ならと “サブュニット”への解裂は僅かに見られるのみで、 大部分は未解裂のままであった。

次に、蛋白分解性 B 型菌 ( O kra 株) の 47 時間培 養液より精製した、トリブシンで活性化される毒素に つレて、活性化とサブニニットへの解裂につんて検討 した。種々の pHでトリプシン処理を行な5と、 $\mathrm{pH} 6.0$ で最高の毒力が得られるが、 $\mathrm{pH} 4.5$ でる活性化は見 られる。そてで $\mathrm{pH} 6.0$ と $\mathrm{pH} 4.5$ での活性化の経時的 変化と SDS 電気泳動での "サブニニット"の出現と を比較した。 $\mathrm{pH} 6.0$ では毒力の上年と"サブュニッ ト”の出現とは、医並行していたが、 $\mathrm{pH} 4.5$ では 活性化が十分に進んだ時期でもなお未解裂の毒素の 存在が見られた。

以上の結果から、毒素の活性化は、トリプシンある いは類似の酵素による毒素分子の“サブュニット”へ の解裂とは並行せず、毒素分子鎖の解裂が見られなん 毒素でもすでに活性化されているととを示しており、 ボッリヌス毒素の活性化汢別の機構によるものと考え られる。 
Phage $\phi_{2}$ の容原化とより産生される Staphylokinaseの精製とつんて

(慈恵医大・細菌)

○藤瀬清隆 桜井進 近藤 勇

目的 黄色ブドウ球菌の産生するFibrinolysin ( Staphylokinase：S A K と略す)の中rは, Winkler らにより報告されたSerotype F phage (S A K並びに $\beta$-hemolysinの産生を同時に支 配する 2 重溶原変換 phage) の溶原化に伴い 産生されるもの，われわれの報告した $\phi_{2}$ phage （Serotype B 亿属しSAKの産生を単独に支 配する phage: Genetics, vol 74, no 2, part 2, 1973 ) の溶原化に伴い産生される もの，phageの支配なしに産生されると考え られるもの等がある。乙れらのSAKの性状を をわめ，その異同を知るととは，一般に Fibrinolysin V関する比較酵素学的な点から も，をたSAKの遺伝支配の面からんつても甚 だ興味ある問題を提供するであろら。われわ れはこの目的のために S A K の精製をすすめ ているが, 今回は上記の $\phi_{2}$ phageの溶原化に 伴い産生されるS AKVついていささかの知 見を得たので報告したい。

\section{材料並びに方法 S A K 産生株としては}

D LーTS ( $\left.\phi_{2}\right)$ 株を使用した。乙の侏は黄色 ブ菌寺島株より Serotype F phage を脱溶原化 して得られた S A K産生能を脱落した脱溶原化 株 D L - T S (一)株に $\phi_{2}$ phage を溶原化して得 た株で，原株より S A K の産生量が大である。 この株を林らのSAK産生用培地（Difco nutrient broth $1 \%$ Yeast extract $0.3 \%, \mathrm{Nacl} 0.5 \%$, G I ycerol $1 \%$ ) 飞接種, $37^{\circ} \mathrm{C} て ゙ 18 \mathrm{hrs}$. 靦拌培養し, その遠沈上清 $(10,000 \times g, 20 \mathrm{~min})$ 在硫安飽和で析出 させ, Sephadex G-75 columnで分画した。 その活性画分を $1 \%$ G I ycine 溶液に透析後, Isoelectric focusing column (PH 5-8) で分画した。抗血清は活性画分 をFreund $の$ complete adjuvantと共
『家鬼に皮下接種, $7 \sim 8 \mathrm{~W}$ 後に booster injectionを行った後, 全採血して得た。 抗体価の上昇は中和試験でその都度測定した。

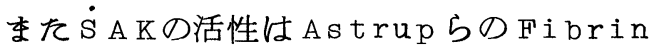
plate法により測定した。蛋白量の測定に はしowry法を用いた。

結果 Sephadex $A-75$ column で分画すると P - I, P - II, P - III の 3 つ活性 peak が得られるが，乙の中で一番安定して出現す るPーII の分画を集め, 最終段階の Isoelectric focusing columnで分画 すると，溶出位置を異にする 4 つ peak ( $\mathrm{PI}=5.7, \mathrm{PI}=5.9, \mathrm{PI}=6.3, \mathrm{PI}=6.7$ ) が得られた。また各peakはP - II に対する 抗血清とMicro-Ouchterlony 法で 1 本の㶩 降線をつくり，かつそれらの沈降線はお互い に融合した。またはー75 PーIIについては今 までのとてろ分子量 25,000 といら值を得て レる。

考察 以上の段階を踏めば， S A K は十分に 精製され，かつ血清学的に同一であるが，電 気永動的に異なる 4 つの component からなる ことが分った。との結果は \&75 P-II を disc electrophoresis (PH9.4) した時に活 性のある 4 〜 5 つ band が出現する事実と あよく一致している。さらにてれらの peak のPI並びに分子量は V 8株でのQV Vesterberg らの結果やその他の報告ともよく一致してい る。尚，P-I，P-III亚びにその他の physicochemical な性状については滕村らの最 近の報告とも照らし合わせ，目下検討中であ る。 


\title{
C-I- 16
}

\section{$C l . p e r f r i n g e n s$ Ent erotoxin産生培地と産生条件について}

\author{
○刑部陽宅坚玉博英（富山衛研）
}

目的

Cl. perfringensの Enterotoxin（以下Ent）産生 に好適な培地を得ることを目的として, Ent 産生 に及ぼす諸要因につんて検討した。

材料と方法

菌株は NCTC8798と易熱性胞子を作る TW224 一1を主に用いた。培盖基の肉水は常法通り作製後, $\mathrm{NaOHでpH7.5とし,} 121 \mathrm{C}, 15$ 分, 加熱濾過して 用いた。Ent産生量の測定は37 C, 2 日培盖上清

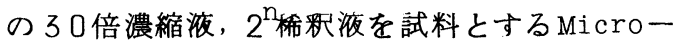

slide Gel diffusion法によった。また,37C, 24 時間培養液について, $\mathrm{pH}$ は $\mathrm{pH}$ 試験紙, 発育は630 $m \mu の$ 吸光度, 胞子形成はWirtz染色と, $70 \mathrm{C}, 10$ 分加熱後, $\mathrm{CW}$ 寒天平板に塗抹培養する方法で測定 した。

結果および考察

供試 2 株は $0.5 \%$ 酵母エキスと $1 \%$ ペプトン（6 種） を栄養源とした培地（ pH 7.5）でEntを産生しな かったので, 酵母エキス 5 g, プロテオーゼペプ トン10g, NaCl5g，チオグリコール酸ソーダ 1 $g$, 水 $1 \ell$ を基礎にラフィノ一ス他 6 種の糖を夫々 5 g加えた培地での Ent産生をみると, N C T 8798が可溶性澌粉存在下でのみ, 陽性となり， 他壮全て陰性であった。乙の場合, 淑粉として, 小麦他 5 種の潘粉を用いても, 結果に大差のない 事等から, 激粉は Ent 産生に重要と考えられた。 次飞, 酵母エキス $5 g$, 可溶性溊粉 $5 g, \mathrm{NaCl}$ 5 g, $\mathrm{Na}_{2} \mathrm{HPO}_{4} 5$ g, チオグリコール酸ソーダ 1 8 , 水1 $\ell$ を基礎に, プロテオーゼその他のペプトン を夫々10g加えた培地 6 種を用いると, 両株とも, 全培地で Ent 産生し，その産生量は TW2 24-1 では, ペプトンによる差は少ないが, NCTC8798 では大きく，ポリペプトンS（大五）添加で多か った。そてで, この培地のペプトンをポリペプト ン S とし, 酵母エキス部分を 6 種の肉水に代えて みた。結果は鷄肉水で, 産生は更に良くなった。
この Ent 産生は, $\mathrm{Na}_{2} \mathrm{HPO}_{4}$ が $0.5 \%$ て最も良く(最 終 $\mathrm{pH} 6.3) ， 0 \%$ 或㤌 $2 \%$ 以上で悪くなった。乙れ は菌培養後の $\mathrm{pH}$ が 4.8〜 6.8の範囲でのみ, Ent が検出される結果（使用 48 種の培地の集計）と 対応する傾向を示すととから， pH も Ent 産生に 重要な要因と考えられた。また，金属塩では, $\mathrm{F} \Theta \mathrm{Cl}_{3} \cdot 6 \mathrm{H}_{2} \mathrm{O}$ が産生量のばらつをを少くした。以 上の結果から, Ent産生培地として, ポリペプト บ $\mathrm{S} 10 \%$, 可溶性溊粉 $5 g, \mathrm{NaCl} 5 \%, \cdot \mathrm{Na}_{2} \mathrm{H}-$ $\mathrm{PO}_{4} 5 \mathrm{~g}, \mathrm{FeCl}_{3} 6 \mathrm{H}_{2} 0100 \mathrm{mg}$, チオグリコー ル酸ソーダ $1 \mathrm{~g}$, 鷄（ささみ）肉水 $1 \ell$ の組成を 採用した。培地は $100 \mathrm{C}, 15$ 分加熱濾過後, 隇菌 した。本培地での, Ent産生を食中毒由来菌, 23 株を用いて検討すると，70\%がD.S培地の 2 25 6倍量の Entを産生し, D.S 培地より産生が劣 っていたのは, 13\%に過ぎなった。をた本培地 における Ent 産生 6 株の胞子形成数をみると, 2 $\sim 7 \times 10^{8} / \mathrm{ml}$ に達し, Ellner, Angelotti, Nishida培地での 0 5×1 $04 / \mathrm{m}$, Kim, D.S 培地で の, $1.5 \times 10^{5} \sim 5 \times 10^{7} / \mathrm{me}$ に比し多加た。形態観 察による胞子形成でも, 本培地は他の培地に比し, 高い頻度を示した。このととは, 本培地はEnt産 生のみでなく,胞子形成培地としてる優れているて とを示するのと考えられる。

N C T C 8798が㮔々の Ent産生量を示した培地 11 種之新培地の可溶性溊粉を $\mathrm{Na}_{2} \mathrm{HPO}_{4}+$, 一状態 で, 他の糖に代えた培地12種を用いて, NCT C 87980 Ent産生量と胞子形成数の相関をみる 之, Ent産生は胞子数, $6 \times 10^{3} / m \ell$ から始をり, 以後, 産生量の増加とともに胞子数は増加した。

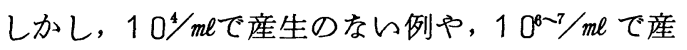
生の少ない例が認められ, Ent 産生は胞子の絶対数 に一義的に依存しない場合もあることが明らかと なった。乙のととは形成胞子の質的な差もEnt 産 生に重要なととを示唆するものと推定される。 


\section{C-1-17}

\section{Clostridium perfringensの菌体外毒素非産生株指の相補性纪ついて(第开報)}

田附ッル, 柳ケ瀬康夫, 井上公蔵, 天野恒久, (阪大, 医, 練菌)

東 㢈（阪大, 医療技術短大)

要約 :

(1) C1. perfringens PB6K 株をニトロソグ アニジン処理して、i)ゼラチン寒天垶地 上で集落の周囲に白濁の生じない変異株 54 株、ii) カゼイン寒天埙地，上で集落の周 囲に凝塊の生じない変異株17株、並)アキ レス腱寒天培地上で集落の周囲にアキレ 不腱微細断片溶解の認められない変異株 8株をそれぞれ分離した。

(2) i)拈よびii)の変異株は、プロテアーゼ 非産生変異株であり、並)の変異株は $\mathrm{k}$ 毒 素非産生の变異株であつた。

(3) これらの変異株にも $\mathrm{a}, \mathrm{b}$ 両群があり、 両群菌間机相補性が認められた。 目的 :

我々は $\mathrm{C} 1$. perfringens $\mathrm{PB} 6 \mathrm{~K}$ 株の $\theta$ 毒素非 産生変異株を用い、 $\mathrm{a}, \mathrm{b}$ 群菌間次、 $\theta$ 毒素産 生の相補が起ること、屯た $\theta$ 毒素非産生株と して分離したにるかかわらず一部の変異株は、 ゼラチン、皮粉、アキレス腱、カゼイン、フ イブリン、等の基質のずて、または一部に 対して非分解性を示すてと、またとれらの基 質非分解性の両群柇留に相補性が㒛められる てと等を本学会で報告してをた。今回は、 他のマーカーで分離した変異株の吽状および 相補吽について報告する。

材料と方法：

墇地：アネローブ寒天培地に $3 \%$ ア゙ラチン、 2\%カゼイン、またはドライアイスと共に粉研 した牛アキレス㯈微細断片を加えたるのを、 それぞれゼラチン寒天培地、カゼイン寒天培 地、アキレス腱寒天境地とした。

垤养上清のゼラチン分解活性の測定 : 㥺 上清の 2 倍階段希釈したものに、等量の0.3\% ゼラチンを加え、37\% 2 時間後、さら飞等量 の館, 和硫安を加えて、生じた沈溉の有無でゼ
ラチン分解活性を測定した。

培養液のプロテアーゼ (凝塊酵素)活性の測 定：酸性に移行している培養液を中和し、最 終濃度、2\%スキムミルクと $\mathrm{M} / 100 \mathrm{CaCl}_{2}$ を 加えて、生じる凝塊の有無で判定した。 結果 :

I. C1. perfringens PB6Kを NG处理して、ゼ ラチン寒天培地上で集落の周囲に白濁の出な い株を変異株として分離した。この変異株は、 飽和硫安を重層すると、親株と比べやや小さ い透明環を示す。2工株についての却養上清の ゼラチン分解性は親株と比較して1／4 及至 1/100 の活性であつた。アキレス腱分解性は、 弱遅分解性を示す。ところがカゼイン分解性 はカゼイン寒天地上及び地養上清の凝塊形 成活性と多に陰性であつた。

2.カゼイン寒天垶地上で集落の周囲に凝塊 の生じない株を変異株として分離した。との 変異株の培養上清のゼラチン分解活性は親株 と比較して】/2及至】/100である。またアキレス 腱分解性は弱 (遅) 分解性を示した。乙れらの

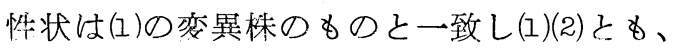
プロテアーゼ非産生恋異株と考えられる。

3.アキレ不建寒天垶地、上で集落の周囲に、 アキレス腱溶解のない株を変異株として分離 した。との変異株は、ゼラチン分解性子カゼ イン分解性子認められ、以毒㨞韭産生弯異株 である。

4.上記変異株は、それぞれの基質け寒天培 地で a 群と b 群の standardの変異株と cross streak すると、必ずどららかの群のstandard 変異株と相補を示す。乙の相補性办ら(1)の変 異株 54 株中 6 株が b 群であり、他はすべてa 群の恋異株であつた。 


\section{伝達された毒素産生能の安定性について 一その2 -}

北大 医 細菌

\section{目的}

ボッリヌスC 型、D型菌におらては、有毒 侏を植えかえているらちに、時には、保存し ているだけで無毒株に変わる事が報告されて らる。我々は、フアージ感染沉より無毒株 から有毒怢飞変換された菌を用い、毒素産生 能の安定性を観察するとともに、上記現象の 理由を明らかにするため、以下の実験を行な つた.

\section{方法}

無毒株 $\mathrm{C}-\mathrm{A} 02 、 \mathrm{D}-/ 39$ 亿有毒株 $\mathrm{C}-$ $\mathrm{Stockholm}$ 由来フアージ c-st 株 D-/5/ 亿有毒株 D-/873、C-203 由来 ファージ d-1873、C - 203 を作用させ、有 毒株に変換された菌（コロニ一）をorigin とし、これをcooked meat (CM) 培地で 10 代汽継代を抏てなた。継代は、37 C、 18 時間培食上清 $0.2 \mathrm{ml} / 0 \mathrm{mI}$ の CM 培地に 移した. 各代において、約 20 個のコロニ 一飞拾々、37C、3 日間培養後毒性試験を标 こない、毒素産生能の安定性を觀祭した。 A 02 ( c-st) 扎よび /5/(d-1873). 15/(c-203) の系に、それぞれ抗 $c-n 7 /$ および抗 $\mathrm{d}$ お/873 フアージ血清を加え、 同様の実験を試みた，得られた無毒株は、そ れぞれの親フアージに作用させ、溶菌および 有毒株へと変換されるか否かをみた。

\section{結果および考察}

抗フアージ血清を加えない時には、15/ (d-1873) 以外の系に秃て無毒化ををた した。この時得られた無毒株はすべて、そ れぞれの親フアージにより感染されず、溶菌 子、有毒株へと変换もされなかつた。１5/ (d-1873)の系では、4代目頃にいつたん
小熊恵二飯田厸夫塩崎満子 無毒株が出現したが、その後、再び任とんど のコロニーが有毒株となつた，得られた無毒 株は親フアージ d-1873により溶菌され、 有毒株へと変換された。

抗フアージ血清を加えた時には、すべての 系におらて無毒化が早くおこり、得られた無 毒株は (プレ) プロフアージをcureされ たものであつた。

すべての系に挑いて、坑フアージ血清を加 えずに继代した時には、その/8時間培盖上 清を指示菌に作用させると、高率に毒素産生 能の伝達をおこした。

以上の事より、C 型、D型の両系におらて は、毒素産生に関与する遺伝子は非常に不安 定なものであり、ある系においては再感染を おこすが、他の系では、再感染をされないよ らな無毒株が出現し、すみやかに無毒化をを たすものである事が分つた。乙のよらな、 親フアージに感染されない無毒株の出現が、 C 型, D型における無毒化のおこりやすい理 由と考えられる。抗フアージ血清を加える 事によりその出現が执さえられる事から、変 換フアージと抗原性の等しい、非変換フアー シにより溶原化された菌と考えて現在検討中 である。 


\section{$C-1-19$}

ジフテリア毒素合成能の異る $\beta$ ファージ変異株の分離とてれ を用いての解折

○,内田驍, 金井知恵, 米田正彦 (阪大 - 微研 )

要約

1） ジフテリア毒素合成能の低下したいく つかの $\beta$ ファージ変異株を分離した。これらフ ァージによって得た溶原菌の毒素産生量は親株 の 5〜 10,1〜3, および0\%であった。

2）乙の変異ファージの溶原菌に $\beta_{45}$ ファー ジを重感染して培養したとてろ, 毒素と $\mathrm{crm}_{45}$ の産生量には共に影響はみられなかった。 目的

ジフテリア毒素の構造遺伝子はファージ $(\beta$ ᄀ ァージなど)によって運ばれ，てのファージによ って溶原化された菌からの毒素量は鉄によっ て制御されるほか, 菌の生理的条件によって 影響をらけ，乙の場合宿主である菌側の因子 が関与すると言われている。今回はファージ側 の factor によっても毒素産生量に影響をおよ ぼすかどうかを明らかにし，さらに毒素合成 に伴って制御をらける蛋白の存在の有無を知 るためにこの研究を行った。

材料と方法

$\mathrm{C}_{7}(-), \mathrm{C}_{7}(\beta)$ 菌を用い, ファージは $\beta$ とか Uchida らにょって分離された $\beta_{45}$ (分子量約 45,000 の crm45 産生する形質をるつ）およ び Matsudaらによって分離された $\oplus 21\left(38{ }^{\circ} \mathrm{C}\right.$ でDNA replication が阻害される early funetion の mutant) を用いた。

紫外線感受性変異菌 $C_{7}^{\text {US }}(-)$ はnitrosoguanidine $(20 \mu g / \mathrm{mI})$ でC $7(-)$ を15 分処理しレプ カ法によって分離した。

変異ファージの分離は毒素の構造遺层子に変 異をおこした phage を得たのと同様な方法で nitrosoguanidine.で処理し, turbid plaque 中の菌を馬抗毒素を含む除鉄 - tryptose yeast Extract- 寒天平板培地へ移して培養 後, 集落の周囲に haloの形成能の無々ものを 選び, Single colony isolationして溶原性を テストした後, CYT培地で培養し培養上清中 の毒素の.上丨 と毒性を測定した。的は

125I-Toxin,BAC-Antitoxin を用いた RaAioi一 mmunoassaykより，瑇性怔家鬼支内反応和上 びモルモットの最小致死量によった。
培養上清中の毒素や crm45 の解析は S D S polyacrylamide gel 孝用いて行い。NAD： EF2-ADPribose transferase活性 ( "酵素 活性”）の測定には ${ }^{14} \mathrm{C}-\mathrm{NAD}$ と家兔赤血球より 得た EF2 考用いた。 成績と考察

$\mathrm{C}_{7}(\beta)$ 考紫外線照射後Nitrosoguanidineで 処理するととにより毒素合成能の低下した 4 種の異るファージ変異株をえた。これら変異 ファージで $\mathrm{C}_{7}(-)$ を溶原化して得を溶原菌 $\mathrm{C}_{7}$ $(\beta \mathrm{Lt} 3), \mathrm{C}_{7}(\beta \mathrm{Lt} \mathrm{t}), \mathrm{C}_{7}(\beta \mathrm{Lt} 25)$ 就よび $\mathrm{C}_{7}(\beta \mathrm{Lt} 31)$ を毒素産生の至適条件で培養しその毒素産生 量を測定すると，それぞれ親株の 5〜10,1〜3, 0.0001 および0\%であった。またてれら菌 の内部にも毒素は蓄積されていなかった。さ らにこの菌の培養上清を濃縮し SDS-polyacrylamide gel で解析した結果, 分子量䄪 62,000の毒素の位置に細レバンドが $\mathrm{C}_{7}(\beta \mathrm{Lt})$ と $\mathrm{C}_{7}(\beta \mathrm{Lt}$ ) $)$ V未いてはみとめられる他，分子 量の低い位置に数本の minor band が多られる がこれらは“酵素活性”をもっていないととな ぞから毒素由来のものでなく, $\mathrm{C}_{7}(-)$ の培養 上清にもみられるものである。なおてれらの 菌より産生される毒素の比活性（毒性/的お よひ瑇性/蛋白) は親株より産生される毒素と 変らなかった。以上のような毒素産生能の低 下した形質はファージによって運ばれる。

このような毒素産生能の低下は phage gene からの product level によるものなの かをたは gene levelの夕によるものかを知る ために，乙れら溶原菌に $\beta_{45}\left(\mathrm{crm}_{45}\right.$ の産生率 は毒素と同じ)をSuperinfeetして 2 時間半培 養後, その産生された毒素を測定したとてろ, 非感染の場合と変らなかった。をたての培養 上清を濃縮して polyacrylamide gelて解折し たととろ crm45 の産生量の減少はみとめられ ず親株に Superinfectした場合との相違はみ られなかった。

以上のととから毒素産生能にファージ側の 因子関与し，乙の場合 phage gene からの product level によるるのでないと思われる。 この変暴ファージを用いて, 毒素と共にそ の合成の制御をらけている蛋白の存在の有無 を知るため, 紫外線感受性菌, $e^{21}$ と $\beta$ 七 9 の recombinant phage, ${ }^{14} \mathrm{C}$ アミノ酸, SDS polyacrylamide gel孝用いて解折定行っている。 
○潮田弘, 寺山 武, 善養寺 浩 (都衛研微生物)

目的

Staphylococcal Scalded Skin Syndrome (Ritter 型T EN ) は黄色ブドウ球菌（以下 ブ菌と略) の産生する毒素 (以下 $\mathrm{Exf} \cdot \mathrm{toxin}$ と略）によるものであるてとが諸家の研究によう て明らかにされてをた。しかしながら，生体にお ける本毒素の産生については，まったく明らかに されていないばかりか, in vitroでの産生条件 も十分検討されていない。そてでまず, T EN 患者 由来黄色ブ菌のin vitroでの Exf.toxin 産 生を検討したので，その成績につんて報告する。 方法

供試菌株：コアグラーゼ V 型（ファージII群） のS S S S 患者由来 T 4 株を用いた。

毒素産生用培地：Melish らの報告したTrypticase Yeast-extract培地を用いた。

培盖方法：振盪温度勾配培盖装置 ( 東洋科学産 業)を用い， 上字管に前記培地を $15 \mathrm{~m} \ell$ 入れ，搔 取り洗涤菌を6×104/mer接種した。設定温度

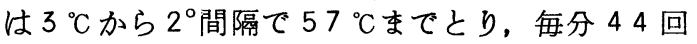
つ振盪培養を行なった。

生菌数測定：常法により行なった。

溶血活性測定：各試料の希粎液 0. $5 \mathrm{meV} 1 \%$ ウ サギ血球液を等量加え, $37^{\circ} \mathrm{C} 2$ 時間 (以下 $\mathrm{h}$ 之略) 後の溶血の有無索観察判定した。なお, 溶血活性 值は $50 \%$ 溶血以上のものをとった。

$\mathrm{pH}$ 測定：微少 $\mathrm{pH}$ 結合電極を用いて行なった。

Exf.toxinの測定：精製毒素でウサギを免疫 して得た抗毒素血清を用いて，女ずS工id ar gel diffusion法によるゲル内沈降反応 の定性法により，Exf.toxinの有無を検討した。 さらに，あらかじめ精製毒素を用いて検量線を求 め, Oudin tub日法により定量測定を行なった。 生物活性測定：ゲル内沈降反応で明らかとなっ た試料 $0.05 \mathrm{~m} \ell$ を听atal miceの背部に接 種し，表皮剥脱活性を測定した。
結果および考察

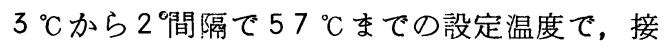
種菌量 $104 / \mathrm{m} \ell て ゙$ 培養を開始し, $8 \mathrm{~h}$ 後增殖の認

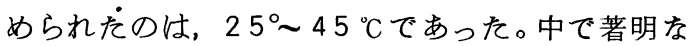
增殖を示したのは $43{ }^{\circ} \mathrm{C} て ゙, 10^{8} / \mathrm{m} \ell$ に達した。 Exf.toxin 産生を認めたのも乙の時間で, $37^{\circ}$

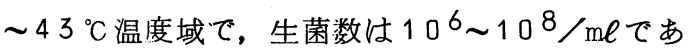
った。毒素産生量の最も多かったのは，やはり

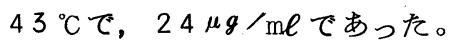

培養時間が進むにつれて，菌の増殖つ認められ る温度域は拡がり、Exf。toxinの検出される温 度域も $24 \mathrm{~h}$ 培盖では $27^{\circ} \sim 45^{\circ} \mathrm{C}$ と拡がった。48 $\mathrm{h}$ 培養後には $15^{\circ} \sim 45^{\circ} \mathrm{C}$ と広い温度範囲から $\mathrm{E}-$ xf。toxinの産生が認められ, 毒素量の最も多く

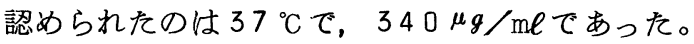

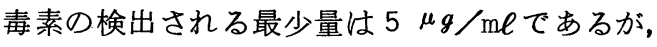
毒素が証明される時点の生菌数は $106 / \mathrm{m} \ell$ 以上 であった。

Hemolysin 活性の最も早く認められる温度域 は $43{ }^{\circ} \mathrm{C} て ゙, 18 h$ 培養で認められ，48h 後には 溶血活性がわずかに低下した。供試菌怢は $\boldsymbol{\alpha}$ 一 Hemolysin 産生が悪い株であるが, 48 h後に溶 血活性が認められた温度域は $25^{\circ} \sim 43^{\circ} \mathrm{CC゙あった。}$ $\mathrm{pH}$ の変動は $12 \mathrm{~h}$ 以降加 $37^{\circ} \sim 43^{\circ} \mathrm{C}$ 温度域 で，菌の增殖とともに，わずかに変動し， $48 \mathrm{~h}$ 培養後の $\mathrm{pH}$ は $31^{\circ} \sim 43{ }^{\circ} \mathrm{C}$ もので, 大方 $\mathrm{pH}$ 8. 0 〜 8.20 程度にアルカリにかたむいた。

Exf。toxinがアルカリで非常に安定なとと ろから。培羑時間とともに蓄積されるものと解さ れる。

生物活性は明らかにゲル内沈降反忘像と一致し た。最子産生量の多かった $37^{\circ} \mathrm{C}$ 温度域の試料を 生食で希釈し, neonatal mice 亿接種した結 果, 32 倍希釈まで明らかに表皮剝脱活性を示し, $160 \sim 200 \mu \mathrm{g} / \mathrm{m} \boldsymbol{\ell}$ 以上と推定され, oudin tube 法によるExf。toxin測定值とほ压一致した。 


\section{緑膿菌のミンク鼻腔内噴霧に対する O E P クチンの感染防御能}

○清水 健 (家畜衛試), 本間 遜, 岡田和夫 (東大. 医科研), 梁川 良 高島郁夫, 藤本 胖, 南出正樹, 野田 寛 (北大·獣医)

目的： ミンクにおける緑膿菌感染症の集団発 生例は古くから知られている。しかし, 緑膿菌の ミンクに対する人工感染は, 従来の報告によれば 必ずしも確実に成功するとは限らないようである。 最近われわれは緑膿菌の鼻腔内注入により, ミン クを確実に感染・発症死させらるととを報告した (Infect. Immun i ty, 10, 16, 1974)。

一方, 本症に対する従来の死菌ワクチンは, 木 モの血清型菌の場合のみ有効であるのに比べて, O E P ( 緑膿菌内毒素蛋白部分, かつ全血清型菌 の共通抗原) ワクチンは, 攻撃菌株の血清型とは 無関係に感染防御能を有することをマウスで示し ている (Ist. Int. Congr. Bacteriol. Abstr. vol. 2. p.213)。庎ミンクにおいても，例えば本ワク チンの $2,500 \mu \mathrm{g}$ 免疫群を, $\mathrm{NC}-5$ 株 ( $1 \mathrm{MLD}$, 血清型 5 ) あるいはN 5.5 株 ( $100 \mathrm{MLD}$, 血清型 8 ) で攻撃した場合の生残数/供試数は, それぞ れ $5 / 5$ (対照群 $1 / 5), 3 / 5$ (対照群 $0 / 5$ ) であ った (第 78 回日本獣医学会)。

今回は自然感染にさらに近似させるために; 緑 膿菌の鼻腔内噴蓩による攻撃法を用いた場合の本 ワクチンの効果について検討した。

方法：OEP の調製法はHomma et al.(Japan J. Exp. Med., 42, 23, 1972)の方法飞従い, 使 用時飞Freund $\oslash$ incomplete adjuvant と混合 した。

ミンクは17か月齢のSapphire 種 9 60 頭を用 レ, 20 頭宛の 3 群に分け, うち 1 群を対照とした。

OEP ワクチンは 3 週間間隔で 2 回, 合計 $4 \mathrm{mg}$ あ るいは $2 \mathrm{mg}$ を皮下接種し, 3 週間後に攻撃して 25 日間観察した。攻撃に際しては, 手動式のヒト用 噴務器の先端に, 長さ約 $1 \mathrm{~cm}$, 直径約 $1.2 \mathrm{~mm}$ の柔 軟なビニール製ノズルを付け，乙れを鼻腔の甲介 骨の梁さまで確実に插入してから, 菌液を噴蓩し た。菌株はミンク病巣由来 $/ 6.5$ 株 (噴第場合の $\left.\mathrm{LD}_{50}: 3.2 \times 10^{6}\right)$ を用い, その普通寒天培地上一夜
培養菌をトリプトソイ・ブイヨン中にかをとって 浮遊させ, 乙の浮遊液 $0.5 \mathrm{~m} \ell\left(\right.$ 菌量： $7 \times 10^{6}$ ) を ミンクの何れか一側の鼻腔内に噴霧した。

OEP-HA反応の手技は Tomiyama et al. (Japan. J. Exp. Med, 43, 185, 1973) の方法に従 ら, 各群 10 頭 分の血清飞ついて測定した。

結果：耐過生残したミンクの頭数を, OEPワ クチンの接種量ごとに示せば， $4 \mathrm{mg}, 2 \mathrm{mg}$ および 対照の各群 20 頭中, それぞれ 19 頭, 1.7 頭, 10 頭であった。生残例においては, 臨床症状は全例 陰性, 剖検所見に著変は認められず, また, 接種 菌の内部藏器からの回収は质とんど陰性で, むれ 飞気管で弱陽性であった。死亡例て和いては, 全 例が喀血を伴い, かつ, 剖検所見では出血性肺炎 が顕著であった。また, 接種菌は全例の内部藏器 から回収された。

OEP-HA力価につんては, 免疫前では全例が $>40$ 倍, 攻撃直前では, 4 mg危疫群が 160 倍 640 倍 (平均 432 倍), 2 mg免疫群が 160 倍 1,280 倍 (平均 480 倍), 対照群が 1 例のみ 40 倍, 残りの 9 例忙 $>40$ 倍 (平均 $>40$ 倍)であった。

考察：攻撃されたミンクの生残率については, 対照群に比べて，4 mg免疫群では $1 \%$ 危険率で, 2 mg 免疫群では $5 \%$ の危険率で, それぞれ対照群 との間に有意差が認められた。とのととから, OEP ワクチンの緑膿菌に対する感染防御能が証明され た。

OEP-HA力価の意義については, 免度後にて の力価が例外なく上昇していることから，ての力 価が OEP免疫の指標となりらるのは当然のとと と思われる。そしてをた，乙の高い力価を有する 免疫群は, この力価を㴗とんど持たない対照群に 比べて, 感染防御能についても有意差を示したこ とから, OEP-HA 力価感染防御能飞つんても 一応の指標となりえよう。 


\section{C-1-22}

レプトスピラの型特異抗原決定基に関する研究

蛋白が関与する可能性について

。足立吉数、梁川良 (北大 - 獣医 - 家畜衛生)

要 約

1. Leptospira kremastos 京都株型特異抗 原の酸加水分解物のクロマトグラフィーによって 得られた画分、および脱脂型特異抗原の透析外液 などの中性糖のみを含む画分、ならびに市販の単 糖は補体結合阻止作用を示さなかつた。

2. 大量のアミノ糖と少量の蛋白を含む画分は、 アミノ糖量に比例して阻止作用を示すことはなく、 また市販のグルコサミンおよび部分加水分解キチ ンも阻止作用を示さなかつた。

3，蛋白のみを含む画分はわずかながら阻止作 用を示した。そして脱脂型特異抗原の透析内液は 強い補体結合阻止作用を示したが、その阻止作用 は蛋白分解䣲素処理で消失した。

目 的

レプトスピラは多くの血清型に分類されている。 しかし、血清型を規定する型特異抗原決定基につ いてはほとんど解明されておらず、糖が関与する のではないかと想像されてきた。我々はL. krem一 as tos 京都株を用以、その型特異抗原決定基の解 明を目的に実験をしている。

材料および方法

京都株型特異抗原の分離、精製はShinagawa \& Yanagawa ( Infect.Immun.,1972 )の方法飞 従つた。抗原決定基の検索はWasserman \& Levine (1961)の方法に従い、型特異抗原の加水分解 物およびそのDowex 50 カラムクロマトグラフイ 一に上って得られた画分が、型特異抗原とその免 疫血清との間の補体結合反応を阻止するか否かで 測定した。

結 果

型特異抗原の酸加水分解物の補体結合阻止作用 は、 $2 \mathrm{NHC} \ell 2$ 時間水解物が糖量 $200 \mu \mathrm{g} / \mathrm{m} \ell$ で 100 \%の阻止率を示したが、1 $\mathrm{NHC \ell および} 0.5 \mathrm{NHC \ell}$ 1 時間加水分解物は任とんど阻止作用を示さなか つた。そこで阻止物質を分離しようとして $2 \mathrm{NHCl}$
2 時間加水分解物をDowex 50 カラムで分画した。 その結果、中性糖のみを含む画分には阻止作用が みられず、大量のアミノ糖と少量の蛋白を含む 3 つの画分には、わずかながら阻止作用が認められ たが、その阻止作用はアミノ糖量に比例しなかつ た。蛋白のみを少量含む画分には、わずかではす るが阻止作用が認められた。

しかし、以上の画分の補体結合阻止作用は低か つたため、阻止作用の高い物質を得ようとして、 型特異抗原を $1 \mathrm{NHC} \ell$ 4分加水分解し脂質を除々 た。乙の上清を透析し、透析内液と外液とを得た。 これらの阻止作用を調べたところ、透析内液のみ 飞強租止作用が認められた (中性糖 $3.3 \mu \mathrm{g} / \mathrm{m} \ell$ で 60\%の阻止率)。透析内液は中性糖、アミノ糖

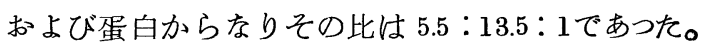
中性糖のみを含む透析外液は阻止作用を示さなか った。

上述の結果から、蛋白が抗原決定基の役割を担 つている可能性が考えられたので、蛋白を破壊す るととを試みた。透析内液をプロナーゼおよびナ ガーゼでそれぞれ $37^{\circ} \mathrm{C} 3$ 時間消化したところ、ア ミノ糖とわずかの中性糖を含んでいたにもかかわ らず、全く阻止作用を示さなかつた。トリプシン 処理では透析内液の阻止作用は約 $50 \%$ 減少した。

市販の構成糖和上び部分加水分解キチンは阻止 作用を示さなかつた。

考察

従来レプトスピラの型特異性は糖によつて規定 されるように想像されてをたが、実験的根拠が無 かった。我々は、以上の結果から蛋白が抗原決定 基に関与している可能性をはじめて示した。今後、 決定基の詳細を検討したい。 


\section{C-1-23}

レプトスピラの菌体構造部分の感染防御能につレて

。高島郁夫、梁川 良（北大・獣医・家畜衛生）

要 約

1. L, icterohaemorrhagiaeのエンベロープ、 細胞壁、および型特異抗原のうち感染防御に最 も 効果のあったのはエンべロープであつた。

2. $200 \mu \mathrm{g}$ のンベロープで免疫されたモルモ ットは強毒株の攻撃に対してすべて生残した。し かし腎レプトスピラ症を完全には防がなかった。

3. エンベロープより抽出した蛋白画分は感染 防御に厓とんど効果がなかった。

目 的

レプトスピラ（以下レと略）の感染防御にあず かる構造部分を明らかにし、効果の最も強い構造 部分からさらに有効な成分を取り出す事を目的と した。

\section{材料および方法}

L. ic terohaemorrhag i ae芝浦株より Shenberg 合成培地飞発育できる変異株を分離し、これ を大量に培養し、得られた菌体からまずAuranら （1972）の方法によりエンベロープを分離した。 残りの菌体より S D S 処理、分画遠心、トリプシ ン、および D N ase 処理により細胞壁を分離した。 これらの調製物はムラミン酸の含量の測定および 電子顕微鏡観察により精製度をたしかめた。型特 異抗原は Shinagawa \& Yanagawa (1972) の方法 により分離した。エンベロープからの蛋白画分は、 Homm aら (1966) が緑膿菌のエンドトキシンの蛋 白部分を分離した方法に準じて分離した。それら を300 400 gのモルモットの皮下に接種して免疫 した。比較のために加熱死菌および生菌の凍結乾 燥物（生菌のいない事をたしか奴）る用いた。 2 週間後に強毒の芝浦株 $10^{7}$ コで攻撃し、その後 2 週間観祭し、生死小よび堅からのレの回収の有 無により防御効果を判定した。

結 果

エンベロープおよび涷結乾燥死囷のそれぞれ $200 \mu \mathrm{g}$ およ゙ $40 \mu \mathrm{g}$ で免疫されたモルモットはす
べて生残した。同じ量の細胞壁で免疫されたモル モットの生残は $6 / 7$ おび $4 / 7$ 、型特異抗原のそ れは $2 / 4$ および $2 / 4$ 、エンベロープの蛋白画分で

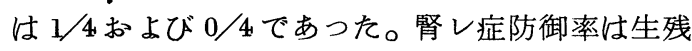
率より低かつた。したがつててれらの調製物でた とえ感染死を防いでる、腎レ症を完全に防ぐこと は困難であった。各調製物 $200 \mu \mathrm{g}$ 免疫で50\%以 上腎レ症を防いだのはェンべロープだけであった。 考 察

今回の成績より感染防御能は主として最外層を 構成するエンベロープにあり、ついで細胞壁およ び型特異抗原にもあるととが判つた。型特異抗原 はエンベロープ中に存在すると考えられており、 また本症の獲得免疫は血清型に特異的なので、と くに型特異抗原の活性を高めるのにはアシュバント が必要なのか子知れない。エンベロープの蛋白画

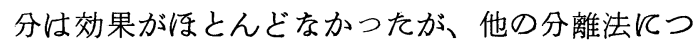
いて検討してみる必要があると考えられる。

各調製物 $200 \mu \mathrm{g}$ の感染防御効果の比較

\begin{tabular}{lcc}
\hline \multicolumn{1}{c}{ 調製物 } & 生残率 & 腎レ症防御率 \\
\hline 凍結乾燥死菌 & $7 / 7$ & $3 / 7$ \\
加熱死菌 & $2 / 4$ & $0 / 4$ \\
エンベロープ & $8 / 8$ & $5 / 8$ \\
同上蛋白画分 & $1 / 4$ & $0 / 4$ \\
細胞壁 & $6 / 7$ & $2 / 7$ \\
型特異抗原 & $2 / 4$ & $1 / 4$ \\
生理食塩水 & $1 / 11$ & $0 / 11$ \\
\hline
\end{tabular}


新しいレプトスピラワクチンの開発

I. 合成培地ワクチンの試製

○喜田 宏・石井 保・渡辺秀夫 - 常久芳直 - 山本繁夫

武田楽品・光・細菌

はじめに：通常、レプトスピラ(レの培養 には血清または血清アルブミン画分を加え た培地が用いられている。健つてワクチン 中に血清成分が持ち込まれる可能性があり、 それが微最でも局所または全身性のアレル ギー反応をひき起す危険がある。

近年、合成培地に関する研究が進み、多 くの㮔類のレの培養が 合成培地によつて可能 となりつつある。中でも SHENBERG(1967) の無蛋白合成培地はレの発育支持力が優れ ていることから、我々はこの培地によつて 現在我国のワイル秋疫混合ワクチンに含ま れる4血清型のレを培養することを試みた。 しかし直接この培地にレを移植した場合は 何れの株も発育しなかつた。我々は先にこ の培地に直接移植した場合は発育できない L.icterohaemorrhagiae 芝浦株加発育変 異菌を得ることによつて培㽰が可能となり 抗原性には変化を認めなかつたことを報告 した(KIDA \& YANAGAWA, 1970)。そこ で、これらレ4株を発有変異菌を林用する ことによつて合成培地で培養可能とし、ワ クチンを試製することに成功した。試製ワ クチンの品躓を血清培地で培養して得たワ クチンのそれと比較し、懮れたワクチンで あると考えられたので報告する。

方法：4血清型のレ ( ic terohæmorrha giae, autumnalis, hebdomadis 拈よ゙ australis） 4 株から上記の方法により発育変 異菌を得、これらを合成培地で培羕し、不 活化, 洗惵, 濃縮, 布粎打よび混合して合 成培地ワクチンを試製した。同時に視菌を 血清培地で培養し、同様操作によつて血清 培地ワクチンを用意した。両ワクチンにつ いて生物学的製郩基隼に拠る諸試験を行な
つた。また、1○CにI年间保存した後に 力価打よび安全試験を行なつた。

䊅果扔よび考察：両ワクチンとも何れの 試験に打いても現行の因家倹定基準を満足 していた。試製した合成培地ワクチンは培 地由米の血清成分を含まないのでこれによ る副反応の危険がないこと、蚠白性窒素量 が非常に小さく、闹様に試憋した血清培地 ワクチンのそれの市桯度であつたこと、力 価は血清培地ワクチンと差を認めなかつた こと、打よび $○$ Cに I年間保存した後も 力価を保持して扣り、安全性が確認された ことから優れた品質であると考えられた。 しかしながら、合成培地ワクチンでもマウ ス执よ゙モルモットの腹腔内に接種したと き、接種1日後にそれらの動物の体重を减 少させる毒性が認められたことから、体重 减少毒性はレ囷体そのものによると考えら れる。今後レワクチンをさらに收良すべき 余地があることを示していると恐われる。 な拓、最近 SHENBERGら（１973）は SHËNBERG 培地に発育し得る grippotjr phnsa s s zwajizak の2株で合成培地ワク チンを試製し、人体実験まで行なつて好成 綪を得たと㧨告していることを付記する。 